
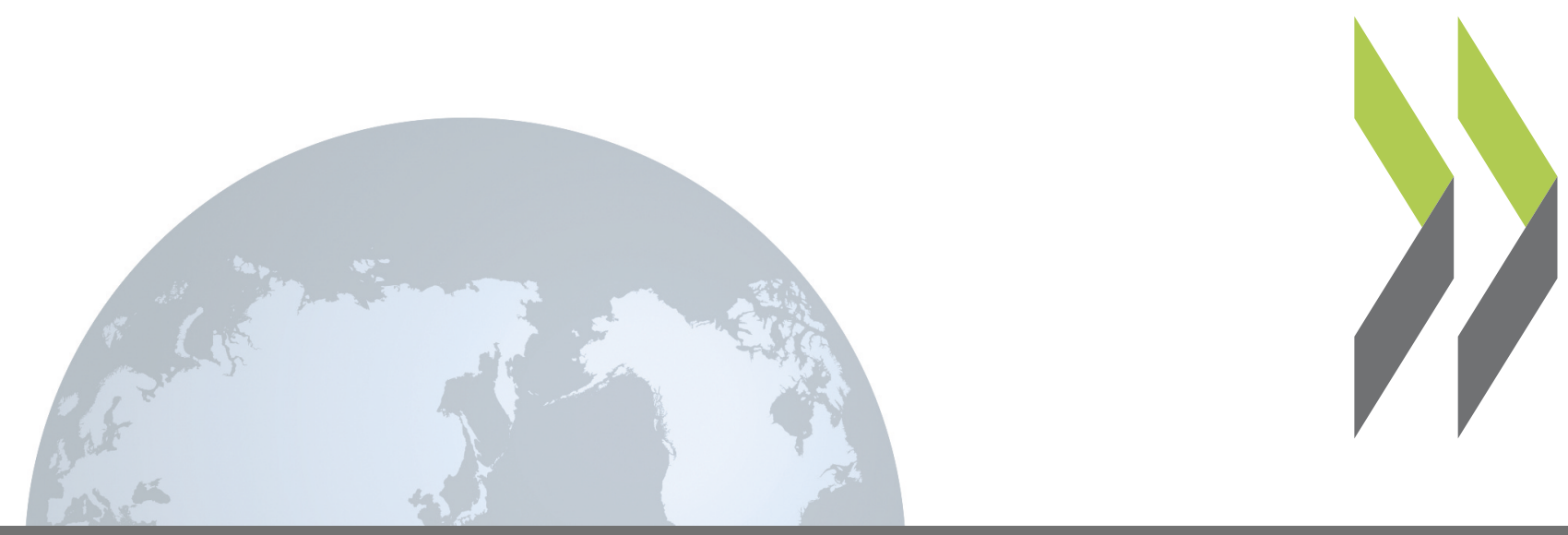

OECD Economics Department Working Papers No. 189

\title{
Income Distribution and Poverty in Selected OECD Countries
}

\section{Jean-Marc Burniaux, Thai-Thanh Dang, Douglas Fore, Michael Förster, Marco Mira d'Ercole, Howard Oxley}


INCOME DISTRIBUTION AND POVERTY IN SELECTED OECD COUNTRIES : ECONOMICS DEPARTMENT WORKING PAPERS No. 189

by

Jean-Marc Burniaux, Thai-Thanh Dang, Douglas Fore, Michael Förster, Marco Mira d'Ercole and Howard Oxley

Most Economics Department Working Papers beginning with No. 144 are now available through OECD's Internet Web site at http://www.oecd.org/eco/eco as are Annexes 2 and 3 of this paper. 


\begin{abstract}
RÉSUMÉ
This working paper presents evidence on changes in income distribution and poverty in thirteen OECD countries over the two decades up to the first half of the 1990s. While country experience has been variable, income and poverty rose in most countries. Both earnings and capital and self employment incomes contributed to these developments, partly offset by an increase in the importance of (progressive) taxes and transfers in total income. Increases in the share of no-worker households appears to have contributed to widening income distribution. Transfers appear to be relatively evenly spread across income groups in a number of countries, reflecting the weight of age-related transfers. An analysis of average incomes and poverty by household type, suggests that the retirement-age population has tended to do better, while younger households and households with children have become less well off and poverty has tended to shift from the old to the young. This mainly reflects maturing pension systems for the retired combined with lower earnings among younger households.

$* * * * * *$

Ce document de travail présente pour treize pays de l'OCDE les changements dans la distribution des revenus et le niveau de pauvreté au cours des deux décennies précédant le milieu des années 1990s. L'expérience des pays diffère, les revenus et la pauvreté se sont accrus dans la plupart des pays. Les gains salariaux et les revenus du capital et des emplois non salariés ont tous deux contribué à cette évolution, en partie compensée par un accroissement de la part des impôts (progressifs) et des transferts dans le revenu total. L'augmentation de la proportion de ménages sans emploi semble avoir contribué à l'élargissement de la distribution des revenus. Dans un certain nombre de pays, l'allocation des transferts qui apparaît également distribuée entre les différent groupes de revenus, reflète le poids de transfert liés à l'âge. Par ailleurs, l'analyse des revenus relatifs et de la pauvreté par type de ménage suggère que la situation de la population à l'âge de la retraite tend à s'améliorer tandis que celle des ménages jeunes et des ménages avec enfants se détériore, la pauvreté ayant tendance à se déplacer des vieux vers les jeunes. Ceci reflète essentiellement la maturité des systèmes de pension pour les retraités et d'autre part des gains salariaux plus faibles chez les jeunes.
\end{abstract}

\title{
Copyright OECD, 1998
}

Applications for permission to reproduce or translate all, or part of, this material should be made to: Head of Publications Service, OECD, 2 Rue André Pascal, 75775 Paris Cedex 16, France. 
TABLE OF CONTENTS

INCOME DISTRIBUTION AND POVERTY IN SELECTED OECD COUNTRIES ............................. 6

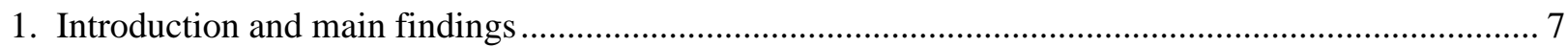

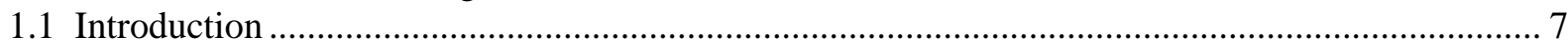

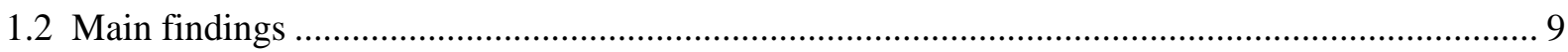

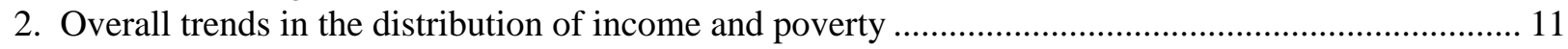

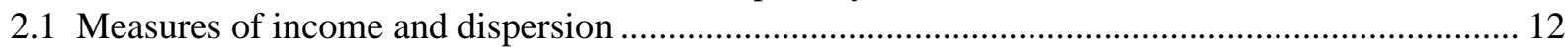

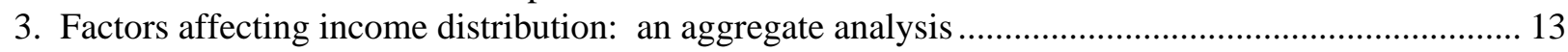

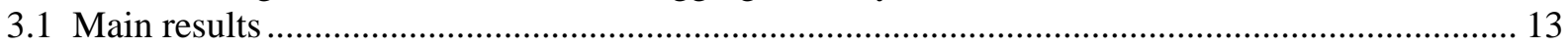

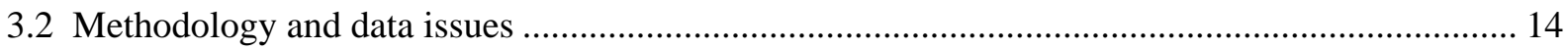

3.3 How the distribution of different income sources has evolved ................................................. 15

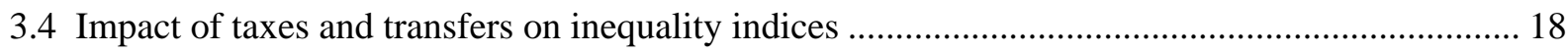

3.5 Contributions of income sources to total inequality and the sources of change in inequality ....... 19

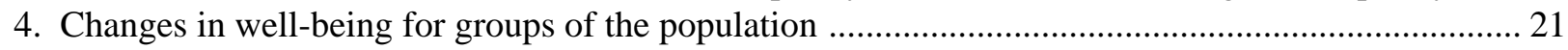

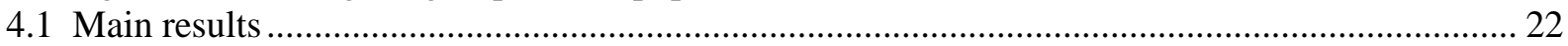

4.2 Levels and changes in relative incomes of sub-groups of the population .................................... 22

4.3 Accounting for changes in relative income of sub-groups of the population ................................ 23

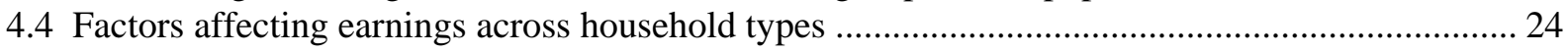

4.5 Developments for population groups of special policy interest .................................................. 25

4.6 Relative incomes and changing work attachment and household structure: the impact on income

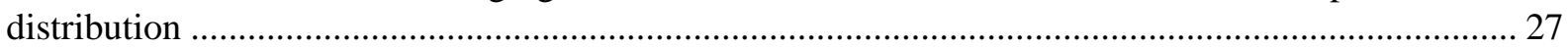

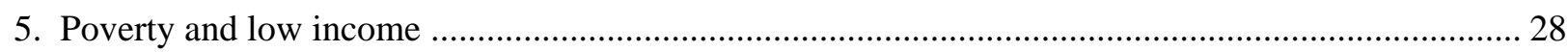

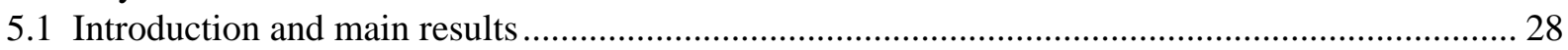

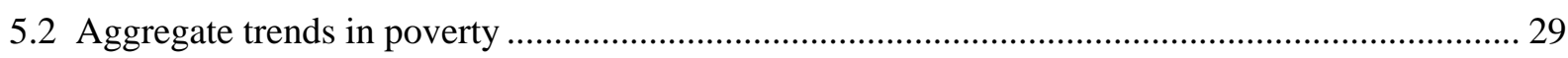

5.3 Poverty rates and the structure of poverty (individuals in the bottom quintile) ............................. 30

5.4 The effect of taxes and transfers in reducing poverty in selected population groups: an analysis

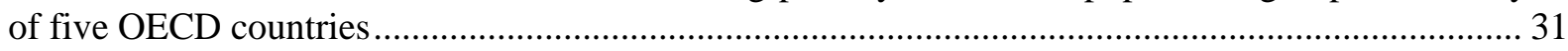

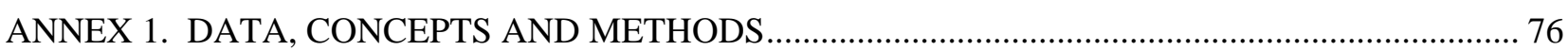

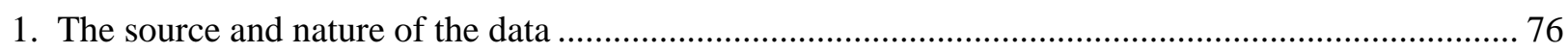

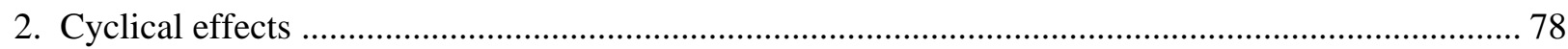

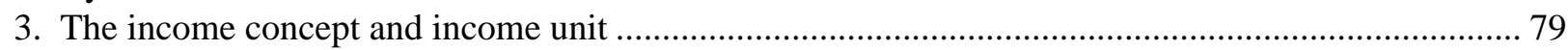

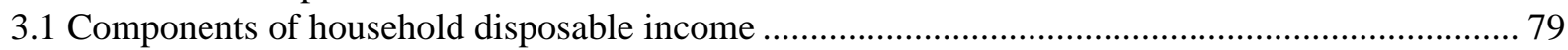

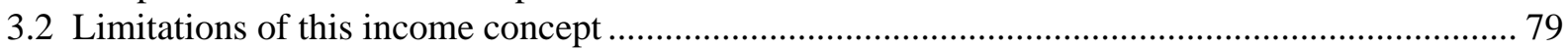

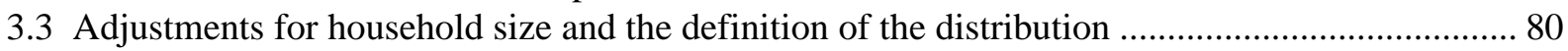

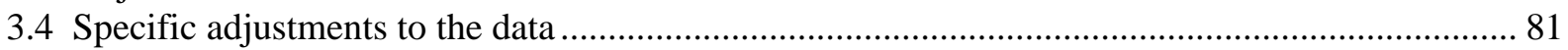

4. Implications of the specific household and income concepts used ................................................. 82

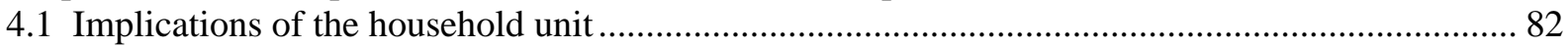

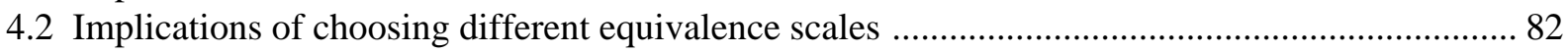

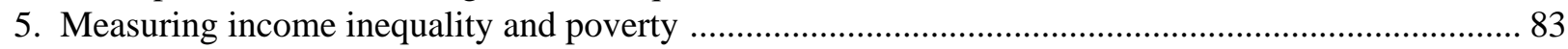


5.1 Inequality indices. .83

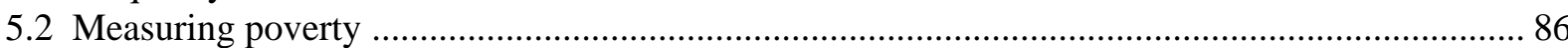

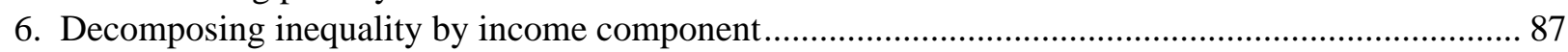

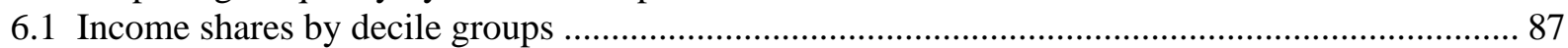

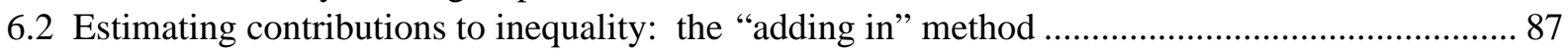

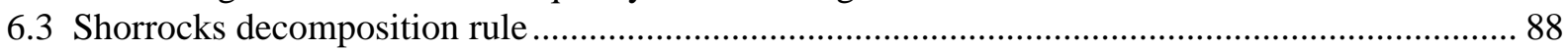

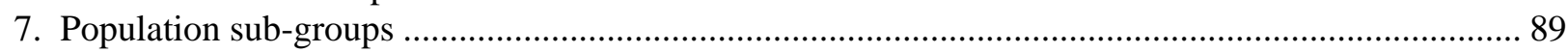

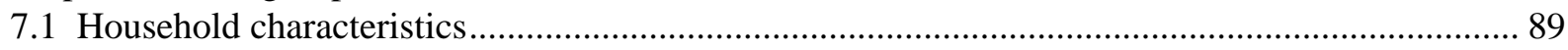

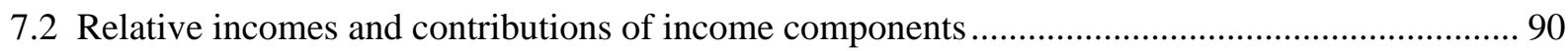

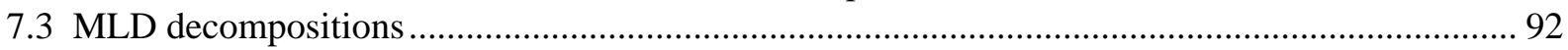

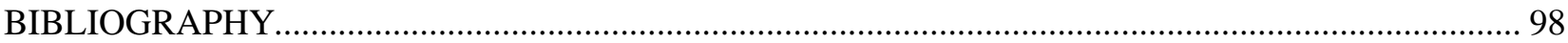

\section{Boxes}

A. The Income Concept: "Disposable Income per Equivalent Household Member"

B. The Shorrocks Decomposition

C. Comparing Decompositions of Income Distribution

\section{Tables}

2.1 Trends in inequality indices

2.2 Overall trends in income distribution: summary results from national studies

3.1 Allocation of income components across decile groups

3.2 Aggregate inequality indicators before and after taxes and transfers

3.3 Contributions of income components to total inequality: Shorrocks de composition

3.4 Decomposition of changes in total inequality: SCV

4.1 Relative disposable income, by degree of work attachment of households

4.2 Relative disposable income, by age of the household head

4.3 Relative disposable income, by family type

4.4 Contribution of earnings and employment to changes in earnings: young and older-worker households

4.5 Contribution of earnings and employment to changes in earnings: households with children

4.6 Relative disposable incomes of non-working households

4.7 Relative disposable incomes of children, the elderly and single earners with children

4.8 Population structure by work attachment and household type

4.9 Changes in inequality: between-group and within-group effects

4.10 Decomposition of the changes in MLD by work attachment 
5.1 Trends in poverty using a relative threshold: mid-1970s to mid-1990s

5.2 Trends in poverty using a constant threshold: mid-1970s to mid-1990s

5.3 Poverty rates and poverty structure after taxes and transfers

5.4 Poverty rates before taxes and transfers

5.5 Structure of poverty before taxes and transfers

5.6 Population structure

5.7 Poverty rates after taxes and transfers

5.8 Structure of poverty after taxes and transfers

5.9 Reduction of poverty due to taxes and transfers

\section{Figures}

2.1 Equivalent disposable income: gains and losses by quintile

4.1 Contribution of income components to changes in relative disposable income, by work attachment of households

4.2 Contribution of income components to changes in relative disposable income, by age of household head

4.3 Contribution of income components to changes in relative disposable income, by family type

4.4 Contribution of income components to changes in relative disposable income: non-working households

4.5 Contribution of income components to changes in relative disposable income: children and single-earner households with children

4.6 Contribution of income components to changes in relative disposable income: non-working households with heads over 65 (the retired)

\section{Annex Tables}

A1.1 Comparison of inequality indices: Luxembourg Income Study and the OECD questionnaire

A1.2 Characteristics of surveys and sample size

A1.3 Contribution of income components to the total change in the SCV index:

a numerical example

\section{Annex Figure}

A1.1 Sensitivity of various inequality indicators to a reduction of income in each decile 


\title{
INCOME DISTRIBUTION AND POVERTY IN SELECTED OECD COUNTRIES
}

\author{
Jean-Marc Burniaux, Thai-Thanh Dang, Douglas Fore, Michael Förster, \\ Marco Mira d'Ercole and Howard Oxley ${ }^{1}$
}

\section{Executive summary}

1. This paper examines the distribution of disposable income and poverty in thirteen OECD countries, focusing on the role of market income, taxes and transfers and the number of household members in employment. The data are (for the most part) based on national survey data, provided by consultants and national authorities using a common questionnaire ${ }^{2}$. In view of possible inconsistencies across countries, the focus is on trends of income inequality within countries, rather than on levels of income inequality across countries.

2. Country experience has been quite variable. Income inequality and poverty rose in most of the thirteen countries. Because earnings are by far the largest source of income, they account for the bulk of income inequality and, in most countries, for most of its increase. Capital and self-employment income, while more unequally distributed than earnings, accounted for a smaller proportion of the observed widening in the distribution of disposable income.

3. Direct taxes paid by individuals and public transfers substantially reduced income inequality and poverty in all the countries examined. The effectiveness of the tax and transfers system strengthened over time, largely because their size increased in most countries over the past 20 years and the distribution of market income widened. Public transfers appear to have often been relatively evenly distributed across

1. This paper would not have been possible without the help of national experts who prepared the underlying data. These include Robert Urquart and Peter Saunders (Australia), Christian Valenduc and Ive Marx (Belgium), Iain Tyrell and Michael Hatfield (Canada), Lars Pantmann (Denmark), Heikki Viitamäki and Esko Mustonen (Finland), Bernard Legris (France), Markus Grabka (Germany), Marco di Marco (Italy), Fumihira Nishizaki (Japan), Peter Heijmans and Hans de Kleijn (the Netherlands), Jon Epland (Norway), Yvla Andersson and Thomas Pettersson (Sweden) and John Coder and Tim Smeeding (United States). Helpful comments were received from Rolf Aarberge, Jørgen Elmeskov, Robert Ford, Flip de Kam, John Martin, Peter Scherer and Paul Swaim. Anick Lotrous and Chantal Nicq provided technical support, while Jackie Gardel and Muriel Duluc produced the document. The usual disclaimer applies.

Howard Oxley is the contact. He can be reached at: tel: (331) 45.24.87.92; fax: (331) 45.24.90.50; email: howard.oxley@oecd.org. Address: OECD, Economics Department, 2 rue André Pascal, 75775 Paris Cédex 16, France.

2. The institutions providing the data were: Australia, Center for Social Policy Studies; Belgium, Ministère des Finances; Canada, Human Resources Development Canada; Denmark, Finance Ministry; Finland, VATT; France, INSEE; Germany, Deutsches Institut für Wirtschaftsforschung (DIW); Italy, Istituto Studi Programmazione Economica (ISPE); Japan, Economic Planning Agency (EPA); the Netherlands, Central Bureau of Statistics/Statistics Netherlands; Norway, Statistics Norway; Sweden, Ministry of Finance; the United States, LIS. 
income groups, mainly reflecting the importance of earnings-related pensions, and this tended to reduce their equalising effect. Taxes had a stronger effect in narrowing income disparities. However, both transfers and taxes are quite progressive in all the countries examined.

4. In general, individuals in households with no workers, in households with a young or an older head, and in households with children had below average income. While changes over time in the relative incomes of the various groups tended to be small as compared to differences in levels at a point in time, the position of households with a young head have tended to deteriorate, mainly due to negative contributions from earnings, reflecting lower earnings among those in work, and in Europe, lower labourmarket attachment as well. The position of households with children also tended to deteriorate.

5. The improvements in the relative position of the elderly was mainly due to the impact of public transfers, an effect that increased over time. This testifies to the success of mature public pension-plan systems in improving the situation of the old. By contrast, the tax-transfer system had relatively less effect on the working and non-working poor under 65 years old. As a result, poverty has tended to shift from the old to the young.

6. These observations point to the possibility of restructuring public programmes to focus on the needs of young households and families with children. The relatively even distribution of public transfers -- which is in part a reflection of pension plans -- suggests that there may be scope for better targeting of these expenditures, especially in countries that have a very extensive transfer system. However, while better targeting would tend to reduce inequalities in disposable incomes and to reduce poverty rates, it may also result in greater disincentives at the low end of the income distribution (perhaps in the form of "poverty" and "unemployment" traps). Therefore, programmes need to be carefully designed and active measures that encourage employment should be favoured over passive measures that may discourage it.

\section{Introduction and main findings}

\subsection{Introduction}

7. This paper examines the distribution of income and poverty in thirteen OECD countries. It also examines changes in the overall distribution of income, how income has been redistributed across social groups, which groups are particularly prone to low incomes and poverty, and the proportion of these groups among the poor. In this context, particular attention is paid to the impact of labour-market developments on the overall distribution of disposable income and on the position of low-income households.

8. These issues have received increasing attention over the past decade. During the period of fast growth in the 25 years between 1950 and 1975, rapid increases in real incomes were accompanied by either stability or some narrowing in the overall income distribution in virtually all OECD countries. However, in the following two decades, not only has the growth of average real incomes decelerated, but in a number of countries income distributions appear to have widened, particularly at the level of market income. The net impact of taxes and income transfers have not always compensated for these developments, leading to declines in disposable income in relative or even absolute terms for certain groups.

9. In this context, the OECD has emphasised the importance of high levels of employment in fostering an equitable distribution of income. The Jobs Study stressed the critical importance of employment growth for reducing the need for income support. Further employment growth needs to 
occur in the private sector if the tax base is to be widened, permitting the financing of needed social programmes. Earlier OECD work (OECD, 1988) also argued that the best way to reduce economic hardship and poverty was to get people back into work.

10. To increase employment and reduce unemployment -- which may themselves help to improve equity -- the OECD formulated the Jobs Strategy (OECD, 1994). A recent review of the experiences of Member countries concluded that the Jobs Strategy could achieve its goals -- if it were implemented in a broad and fundamental way over a sustained period of time (OECD, 1997a). It also found that several OECD Member countries had failed to do so, in part owing to the political concerns that some parts of the strategy could lead to increased precariousness of employment and wider income distributions.

11. In 1991, the OECD commissioned a comparative analysis of overall income distribution in OECD countries using a standardised data set (Atkinson et al., 1995). It concluded that, in the 1980s, taxes and transfer systems reduced income dispersion within countries while leaving wide divergencies across countries. More recent work at the OECD has shed further light on the issue of income distribution. (Annex 3 contains a more complete discussion.) The distribution of earnings of full-time workers -- which approximates the distribution of wage rates, as there is relatively little variation in hours worked in this group -- widened in most OECD countries in the 1980s and 1990s, with the widening being particularly marked in the United States and, from a much more compressed starting point, in the United Kingdom. Moreover, low-paid employment has increased, and is concentrated among the young, women and the unskilled. However, the trends in earnings among full-time workers do not translate faithfully into trends in the distribution of overall earnings. In particular, increases in the average hours worked of part-time workers, as well as higher employment rates (the latter raises the earnings of some individuals from zero) have offset the effect of more unequal wage rates on the distribution of wage income among the working-age population in some countries, notably the United States. Finally, while low wage rates can be an important factor affecting poverty in households working few hours, they may be less of a problem where they supplement the income of a full-time worker. That is, when considering social welfare, a focus on the household may be more appropriate than a focus on the individual.

12. Much less is known about the important issues of earnings mobility of individuals and households over time and about lifetime income distributions, issues which are not addressed in this paper. However, over a five-year period, the earned income distribution becomes slightly more equal due to mobility, largely because the dispersion of income among the young tends to narrow (see "Earnings mobility: taking a longer-run view" in OECD, 1997b).

13. This paper examines in detail the role of taxes and transfers for the distribution of income as well as considering income from capital and self-employment ${ }^{3}$. The time period covered is more recent and longer than in Atkinson et al. (1995). It also explicitly analyses poverty, as distinct from income distributions. Finally, it looks at both the distribution of income and poverty across social groups broken down by work attachment, age of household head and family type.

14. Thirteen OECD countries are considered in this paper (Australia, Belgium, Canada, Denmark, Finland, France, Germany, Italy, Japan, the Netherlands, Norway, Sweden and the United States), although data are incomplete for some of them. The analysis is based on a common questionnaire sent to national authorities and researchers. However, the data are ultimately drawn from national household

3. This paper does not consider in-kind income and public goods and services, although they are important sources of consumption and welfare, and their availability differs significantly across the population groups and countries covered in the analysis (see Annex 1). 
sample surveys and therefore reflect differences in data definitions (for example, for the income included in various income components $)^{4}$. Comparison of these data with internationally comparable data from the Luxembourg Income Study shows that the Gini indices of inequality have virtually the same rank ordering across countries (Annex 1). In any case, the focus of the paper is on changes within each country over time, and it avoids cross-country comparisons of levels of inequality or poverty. The data are for three years: the first, around the mid- to the end 1970s, (referred to as the "mid-1970s"); the second, the early to mid-1980s (referred to as the "mid-1980s"); and the third, the early to mid-1990s (referred to as the "mid-1990s"). However, for Denmark, Finland, France, Germany and Italy data begin only in the late 1970s to the mid-1980s. In general, the beginning and end years differ for each country, sometimes considerably ${ }^{5}$, underlining the caution that should attach to cross-country comparisons on the basis of the data presented here.

15. The key income concept used in this study to estimate inequality and poverty is equivalent disposable income per household member (see Box A and Annex 1, Section 3). Disposable income is first calculated for the household. It is defined as total market income (including private transfers) plus income transfers received from general government less direct taxes (including social security contributions) paid by the household ${ }^{6}$. Equivalent disposable income is calculated as a function of the number of household members. On the assumption that households share common services and thus may enjoy a degree of "economies of scale" in consumption, household income is divided by the square-root of the number of household members to get equivalent disposable income. This equivalent disposable income is then assigned to each individual member of the household to get individual equivalent disposable income. This adjustment to capture the degree of "economies of scale" is somewhat arbitrary. As an alternative, Annex 2 presents results on the assumption of no "economies of scale" (i.e. household income is divided by the number of household members) where they differ significantly from those presented in the main paper.

\subsection{Main findings}

16. The main findings are:

- Trends differ substantially across countries, with only a few being common to all countries.

- Inequality, in terms of disposable income, rose in most countries between the mid-1970s and the mid-1990s (for half the countries, data are available only from the mid-1980s). Poverty rates have also increased in a similar number of countries, but countries with increases in inequality did not always have increases in poverty.

4. The questionnaire specified an extensive set of calculations to be performed using micro-data from the national sample surveys. For further details see Annex 1, Section 1. Section 5.4 of Chapter 5 is based on data drawn from the Luxembourg Income Study and covers only five countries (Canada, France, Germany, Sweden and the United States).

5. Periods are shown in Table 2.1.

6. Employer social security contributions and indirect taxes have not been included although their incidence can have an impact on the distribution of consumption possibilities. Also, private health insurance premiums are ignored. 


\section{Box A. The Income Concept: "Disposable Income per Equivalent Household Member”}

All incomes, taxes and benefits are reported on an annual basis. Household disposable income $\left(Y_{i}\right)$ includes earnings, self-employment incomes, realised property incomes, cash transfers less direct taxes and social security contributions. Current income is deflated by using the CPI relative to the initial year (all incomes are expressed in national currencies of the initial year).

The unit of observation is the household. A household is defined as a collection of individuals who are sharing the same housing unit (but national definitions used can vary -- see Table A2.2).

Equivalent disposable income per household member is defined after adjusting household disposable income for household size, where the adjustment reflects alternative assumptions about household economies of scale. Each individual is attributed the adjusted income of the household. For instance, if $Y_{i}$ denotes the total disposable income of household $i$, the "adjusted" income of each member $j$ of household $i\left(W_{i j}\right)$ is:

$$
W_{i j}=\frac{Y_{i}}{S_{i}^{\varepsilon}},
$$

where $S_{i}$ is the number of members in household $i$ and $\varepsilon$ is the equivalence elasticity.

The equivalence elasticity $(\varepsilon)$ characterises the amount of scale economies that households are assumed to achieve, and range from 0 (an additional household member is assumed to use no extra resources and is equivalent to unadjusted household income) to 1 (no economies of scale, equivalent to a per capita income). The smaller the value for $\varepsilon$, the higher are the assumed economies of scale.

An equivalence elasticity lower than unity implies the existence of economies of scale in household needs: any additional household member needs a less than proportionate increase of the household income in order to maintain a given level of welfare. Under this assumption, the sum over $j$ of individual "adjusted" incomes $W_{i j}$ exceeds the total household disposable income by the amount of scale economies.

The standard or "central case" equivalence scale used in this study was 0.5 . 
- Increased dispersion of labour earnings was the principal cause of the widening in the inequality of disposable income, in part because earnings are such a dominant source of household income. Income from capital and self-employment, though more unequally distributed than labour earnings at any point in time, contributed less to the increase in income inequality over time.

- By far the most important factor determining both relative income and poverty was work attachment (the number of household members in employment) and the development of earnings. Households with no worker were clustered at the bottom of the income distribution and had the highest poverty rates. Households with two or more workers fared the best.

- In all countries, tax and transfer systems redistributed income from the rich to the poor, and reduced pre-tax-and-transfer poverty rates. Transfers tend to be relatively equally distributed over incomes, which blunted (but did not eliminate) their redistributive impact. By contrast, the effect of the direct taxes and social-security contributions paid by individuals was quite redistributive. Over time, taxes and transfers tended to become more redistributive, largely because they increased in size. In general, however, they did not fully offset the widening of the distribution of market incomes.

- Across social groups, it is the elderly that benefited the most from the tax-transfer system, and the benefits they received tended to rise over time. This reflected the operation of public pension plans.

- By contrast, households headed by young adults and those with children fared relatively poorly. This largely reflected developments in earnings. In the United States, this was due to low earnings among those in work, while in Europe it tended to reflect higher unemployment as well.

17. The rest of this paper is in five parts. The next chapter presents a broad overview of changes in aggregate income inequality over the past two decades, emphasising household disposable income and using a range of inequality indicators. Chapter 3 examines the income components which were the source of the change in income inequality. Chapter 4 looks at how individual groups fared and some of the factors underlying changes in their relative income. Chapter 5 examines patterns of poverty, as distinct from the distribution of income. The tables and figures referred to in the main text are at the end of the document and Annex 1 provides technical details on data and methodology. The sensitivity of results to assumptions used in calculating the data is presented in Annex 2, while a literature survey in Annex 3 comments on results from national studies and cites international comparisons ${ }^{7}$.

\section{Overall trends in the distribution of income and poverty}

18. This chapter first examines the evolution of the distribution of disposable (equivalent) income across all individuals over the past two decades at the aggregate level. In sum, inequality increased in most countries. Inequality probably fell in Denmark and France with Canada experiencing broad stability over the entire period. These results broadly correspond with those found in the literature. In some

7. Annex 2 and Annex 3 can be obtained from the Internet address:

http://www.oecd.org/eco/wp/onlinewp.htm. 
countries, these changes may have been accompanied by some "hollowing out" in the middle of the income distributions as indicated by a decline in the share of income going to the middle three quintiles.

\subsection{Measures of income and dispersion}

19. The distribution of income can be summarised by an index number, but there are many possible indices and they do not always yield the same results. This paper uses four widely known inequality indices to measure the dispersion of income: the Gini coefficient; the squared coefficient of variation (SCV); the mean-log deviation (MLD); and the Atkinson index. (See Annex 1, Section 5 for greater detail.) The Gini coefficient is more sensitive to movements around the mean. The Atkinson index is more sensitive to changes at the extremes of the distribution. The SCV and the MLD give more weight, respectively, to the top and bottom of the distribution. Similar movements in all four indices give greater confidence that the indicated change in income inequality is not just a statistical artefact. It should be noted, however, that there is sampling error present in these estimates and, therefore, small changes over time may not be statistically significant. The information needed to compute confidence intervals was not available.

20. Percentage-point and absolute changes in the various indices of income inequality over the entire period and over the most recent sub-period, based on the data collected for this study, are shown in Table 2.1. For countries providing data for the entire period, the four inequality indicators show a widening in the distribution of equivalent disposable income for three countries, with broad stability for Canada and Sweden. Over the most recent decade, there was some decline in inequality in Canada and, according to some indices, in Australia, Denmark, France and Germany as well. For most countries, all the indicators moved in the same direction, suggesting that the results were not due to the peculiarities of any one indicator.

\section{[Table 2.1. Trends in inequality indices]}

21. Figure 2.1 provides additional detail on which quintile groups have been most affected by the changes in income distribution at the aggregate level (quintile 1 is the lowest income group). The bars show the extent to which each quintile lost or gained income shares over the entire period (top bar) and the most recent sub-period (bottom bar). Two groups of countries can be identified:

- Countries where changes in the distribution largely occurred at the extremes of the distribution with progressively smaller movements around the median. This appears to have been the case in Denmark, Germany, Italy, Japan, the Netherlands and Norway. For the last five countries, higher-income groups have gained and lower-income groups fell behind, while the opposite occurred in Denmark.

- Countries where the largest losses in income shares occurred in three "middle-income" quintiles leading to a "hollowing out" of the middle. Such patterns were found to varying degrees in Australia, Belgium, Canada, Finland, France and Sweden (1983-1995) and for the United States (1974-1985, not shown in chart).

[Figure 2.1. Equivalent disposable income: gains and losses by quintile] 
22. While these results are broadly in line with national and other international comparative studies, which are summarised in Table 2.2, there are also important differences, which can reflect a range of measurement issues and the time periods considered ${ }^{8}$. Some important differences are:

- A number of countries (Belgium, Germany and the Netherlands) have excluded households with zero incomes. Since all households have access to minimum support under existing social assistance programmes, they were considered to be incorrectly reported. The number of households with zero reported income was particularly large in Belgium. The MLD index can be particularly sensitive to such choices.

- Certain countries impose cut-off values for higher incomes (referred to as "top coding") for publicly available data. For example for the United States, the small increase of disposable income inequality among individuals shown in Table 2.1 contrasts with the stronger increase in the inequality of gross income (before tax) among households unadjusted for household size calculated by the Census Bureau'. While this may reflect alternative income concepts, data available to the Census Bureau may better pick up developments at the top of the distribution (Annex 2).

- Data collection procedures can change. Inequality indices for Italy remained broadly unchanged until the early 1990s and then increased sharply, partly reflecting more accurate measurement of incomes at the bottom of the distribution.

- Data may not be of a form to pick up certain changes. For France, both market incomes and taxes are net of social security contributions. Data in this format will not pick up all of the impact of the increase of social security ceilings on household income distribution in higher deciles. Hence, income distribution may have narrowed by less than has been shown in Table 2.1 (or may have risen) ${ }^{10}$.

- Finally, important changes in the tax system in the early 1990s in Sweden and the Netherlands led to breaks in the series and there were smaller changes in Finland. For the first two countries, the break was bridged by linking the data.

[Table 2.2. Overall trends in income distribution: summary results from national studies]

\section{Factors affecting income distribution: an aggregate analysis}

\subsection{Main results}

23. This section analyses the aggregate impact of different income sources on overall inequality. It attempts to identify which type of income contributed most to inequality, the extent to which taxes and

8. See Annex 3 for a review of evidence from national and international studies.

9. Gini coefficients for households based on the same household survey used in this study but defined over gross income of households unadjusted for size increased from 0.395 in 1974 to 0.415 in 1984 and 0.45 in 1995. These data treat incomes of high income earners differently but may also be biased upwards because of changes in the upper income limits in the Census Bureau's questionnaire.

10. In addition, the decline in income inequality shown in Table 2.1 seems to have been reversed in the first part of the 1990s (see Annex 3). 
transfers reduced inequality and how these factors have affected inequality over the past two decades. The main results are:

- At any point in time, earnings from labour, which were by far the largest fraction of disposable income, contributed the most to overall inequality, although within-component inequality of earnings (i.e. after adjustment for the size of the component) was lower than for capital and self-employment income.

- Taxes and transfers reduced inequality considerably, although there were wide differences across countries. In many countries, transfers were widely spread across income categories; in these countries, lower-income groups often did not receive significantly more transfers than middle- and upper-income households.

- Over time, greater inequality in labour earnings contributed most to the rise of inequality, mainly reflecting increased inequality among the earnings of the household head, though increasing correlation between the earnings of the two spouses may have played a role (this paper presents no data on this question, however).

- In most countries, the redistributive impact of taxes and transfers increased over time and moderated the increase in inequality at the level of market incomes. However, in most cases this was due to an increase in the share of taxes and transfers in total disposable income, rather than increased progressivity of the tax and transfer systems themselves.

\subsection{Methodology and data issues}

24. For the purpose of analysis, income is divided into four components: labour earnings, self-employment and capital income, general government transfers, and taxes ${ }^{11}$.

25. The accuracy of measurement of these income components differs. Measurement problems are generally small for earnings. Self-employed income differs substantially in definition across countries and in some countries has been included with earnings (Canada and Germany). In general, capital and property income is significantly under-reported and this problem appears to have been particularly important for Belgium and Italy. However, the degree of under-reporting is difficult to judge because other benchmarks -- such as the national accounts -- often treat capital and property income as a residual, leaving those estimates subject to wide error as well. Possibly more important, under-reporting may be concentrated in certain groups. Studies in the United States indicate that it is greatest among the high-income elderly (see Annex 1). Transfer payments are also often under-reported, particularly for income-tested benefits.

26. Finally, taxes have been calculated by simulation models in Germany, Italy, Japan and the United States because this information has either not been collected in surveys or was found to be severely

11. Private income transfers, such as the benefits paid by enterprise-based pension plans, are included in capital income. In what follows, "transfers" refers to transfers received from general government and "taxes" to direct taxes and social security contributions paid by households. 
in error. However, such calculations have errors of their own, particularly where tax systems are complex or provide opportunities for avoiding or evading tax ${ }^{12}$.

27. This section uses three approaches to assess the impact of individual income components on the overall distribution of disposable income:

- The first examines the distribution of the various income sources across deciles. This method is an extension of the familiar Lorenz curve, as it ranks the population in ascending order of disposable income and compares population shares with the corresponding shares of earnings, capital and self-employment income, transfers and taxes.

- The second calculates the impact on inequality indices of "adding in" another income component. In this case, the inequality indicator is calculated for only two components: market income and disposable income (i.e. taxes and transfers are "added in" to market income).

- The last approach uses a method owing to Shorrocks (1982), which permits a more rigorous decomposition of the four income components.

28. Each of these methods has advantages and disadvantages. The first yields results which are easy to interpret, but does not allow a quantification of the impact of each income component on inequality. The second approach is also easy to understand; it allows an estimate of the impact of specific component on inequality, and the sum of the contributions add up to total inequality. However, the size of the contribution attributed to individual components depends on the order in which the income components are "added in". This is because the calculated contribution of each income component depends on both its own distribution and on the degree to which it is correlated with other income components. "Adding-in" components attributes the effect on inequality due to the correlation arbitrarily to the income source which is added last. Further, the contribution will depend on the index used. The Shorrocks decomposition method (Box B) resolves these difficulties, but the results require careful interpretation (see Box C).

\subsection{How the distribution of different income sources has evolved}

29. Table 3.1 shows the allocation of each income component across income categories for all countries except France. Equivalent disposable incomes of individuals are ranked in ascending order and grouped into deciles (as with the Lorenz curve). The disposable income in each decile is then decomposed into the parts originating from labour earnings, capital and self-employment incomes, social transfers and taxes. Each of these income components is then summed across selected deciles and the table shows how each component is distributed across three income groups: $i$ ) lower-income individuals (the three bottom deciles); ii) middle-income individuals (the four middle deciles); and iii) high-income individuals (the three top deciles).

[Table 3.1. Allocation of income components across decile groups]

12. Data limitations and definition problems prevented full data from being included for Canada, France and Norway. 


\section{Box B. The Shorrocks Decomposition}

The Shorrocks (1982) decomposition of inequality across the income components, used in Chapter 3, is additive, yields results that do not depend on any particular inequality index and satisfies a number of restrictions that appear reasonable from empirical and theoretical points of view. Shorrocks showed that total inequality can be uniquely and unambiguously decomposed into income components in a way that obeys six restrictions:

-- $\quad$ symmetric treatment of income components: the contribution of each income component should be independent of how they are ordered;

-- $\quad$ symmetric treatment of population: the contribution of each income component should be independent of how individual observations are ranked;

-- independence of the level of disaggregation: the contribution of each income component should be independent of how many income types are considered;

-- additive consistency: the sum of the contributions of each income component should equal overall inequality;

-- normalisation: the contribution of an income component to total inequality is zero if all individuals receive the same amount of income from that component.

The sixth restriction, the normalisation, warrants further discussion because of the possibility of misinterpretation. Consider a lump-sum transfer of an equal amount to each individual. According to the normalisation rule, this does not contribute to inequality. But it does not imply that such a transfer would necessarily leave the distribution of income unchanged. On the contrary, since after-tax market income is unequally distributed, a lump-sum transfer would reduce income inequality. Put differently, the transfer does not in itself affect inequality, but its presence will modify the inequality imposed by other income components. Indeed, Shorrocks showed that the contribution of any income component is the average of: i) the degree of inequality due to that component, assuming all other components were equally distributed (zero in the case of a lump-sum transfer) and; ii) the change in inequality if that component were equally distributed, given the distribution of all other income components (a reduction in the case of a lump-sum transfer). 


\section{Box C. Comparing Decompositions of Income Distribution}

The table illustrates the Shorrocks decomposition by comparing it with alternative decompositions. For concreteness, the SCV inequality index is applied to data for the United States for 1995. Column 1 is the SCV divided according to the Shorrocks shares. Column 2 shows the SCV for each component, assuming all other components had been distributed equally. Column 3 shows how the SCV would change if the component were distributed equally, given all the other components. Column 4 shows how the SCV would change if a component were removed from total income. And Column 5 shows the SCV contributions of each component as it is "added in", beginning with labour income and ending with taxes.

Comparing Columns 1 and 5, total inequality is the same, but the contributions of the individual income components differ. The "adding in" method attributes the inequality due to the covariance of two components to the second one "added in", whereas the Shorrocks method is symmetric.

Note that the entries in Column 1 are the average of the corresponding entries in Columns 2 and 3, as Shorrocks demonstrated (see Box A). This indicates that a zero Shorrocks contribution is not the same as a zero redistributional effect. Focusing on transfers, the Shorrocks decomposition assigns virtually none of the inequality to them, since they are fairly evenly distributed across households. This is confirmed in Column 3, which shows little change in the SCV if they were exactly evenly distributed. However, Column 4 shows that inequality would rise if transfers were removed -- that is, evenly distributed transfers do improve the income distribution.

$$
\text { United States (1995) }{ }^{1}
$$

Labour earnings

Capital and self-employment income

Transfers

Taxes

Total

$\begin{array}{rrr}1 & 2 & 3 \\ 0.49 & 0.80 & 0.17 \\ 0.16 & 0.25 & 0.08 \\ -0.01 & 0.04 & -0.05 \\ -0.20 & 0.18 & -0.57 \\ 0.44 & 1.26 & -0.38\end{array}$

$-0.38$

\section{4}

2.12

0.09

0.18

0.19

2.57

\section{5}

0.69

0.08

$-0.15$

$-0.19$

0.44

1. With an equivalence elasticity equal to 0.5 . 
30. In all countries, total disposable incomes were more evenly distributed than market incomes, highlighting the redistributive impact of taxes and transfers. Nevertheless, the middle-income and higher-income group received a large share of total transfers: more than half in all countries except Australia. In Italy and Japan, the higher-income group received a larger share of transfers than the lowerincome group. In all countries, taxation is progressive in the sense that the lower-income groups pay less in relation to their taxable income than do higher-income groups ${ }^{13}$.

31. Turning to changes over time, the shares of the two components of market income going to the bottom three deciles fell in all but two countries (but the rise was related to earnings only), and they rose most for higher-income groups (except capital and self-employment income in the Netherlands). Increased unemployment and a larger share of non-working households played an important role in this shift, but the widening in the wage-rate distribution contributed as well. Transfers did not always compensate for these shifts and, indeed, the share of transfers going to the lower-income groups declined in six of the twelve countries, the counterpart mainly being a higher share going to the middle-income group. In most countries, the higher-income group paid a larger share of taxes over time. However, an increased share of taxes was also paid by the lower-income group in Denmark, Sweden and, to a lesser extent in Finland and the United States ${ }^{14}$. Nonetheless, the expansion of transfer programmes appears to have limited declines in this group's share of disposable income, in that, for the bottom three deciles, the decline of the share of disposable income was smaller than that for market incomes in all countries except Germany and the United States. To some degree, this reflected the progressivity of taxes, since a widening in the distribution of market incomes led to relatively more taxes being paid by upper-income groups and less by lower-income households.

\subsection{Impact of taxes and transfers on inequality indices}

32. This section presents estimates of the impact of taxes and transfers (taken together) on income inequality for three inequality indices for ten countries. Data are not available for a more detailed analysis of taxes and transfers taken individually. The results depend on the inequality indicator used, reflecting the fact that each index weights the various income groups differently, and on the order in which the income components are considered. In this case, net taxes and transfers are added to market income, and any covariance effects are thus attributed to the former.

33. The results broadly confirm those found in the previous section (Table 3.2). Net taxes and transfers had a strong equalising effect in all countries, regardless of the indicator used. In terms of changes over time, in all countries, income inequality rose much less in terms of disposable income than in terms of market income, except perhaps in Belgium, Finland, Germany and the Netherlands (where the indicators conflict) ${ }^{15}$.

13. A tax would be proportional if the share of taxes paid by each of the three groups was the same as the share of taxable income received. However, the income components which should be included in the tax base vary depending on the country. In particular, in Denmark, Finland and Sweden, transfers (which are large) are included in the tax base to a greater extent than in other countries. As a result, the share of taxes paid by lower-income groups can be higher than their share of market income and increases in transfers to those groups can lead to higher taxes paid by them as well.

14. See previous footnote.

15. This occurred mainly in countries where the decline in inequality from before- to after-taxes-and-transfers was very large. In any case, absolute (as opposed to relative) changes in the indicators were always smaller at the level of disposable income than before taxes and transfers. 
[Table 3.2. Aggregate inequality indicators before and after taxes and transfers]

\subsection{Contributions of income sources to total inequality and the sources of change in inequality}

34. This section examines the composition of total inequality by the underlying components of income -- earnings, capital and self-employment income, transfers and taxes. Total inequality is broken down into its components using the decomposition developed by Shorrocks (1982). This decomposition does not depend on a particular index of inequality, does not impose a prior ordering on the income components (as does, for example, the "adding-up" exercise of the previous section), and guarantees that the contributions of each component to overall inequality sum to total inequality. (See Box B for more details.) This decomposition is then applied to the SCV index to "explain" the increases (in most countries) in the inequality of disposable incomes in terms of $i$ ) changes in the importance in disposable income of each component; and ii) changes in the distribution of the components themselves.

35. The left-hand panel of Table 3.3 shows the Shorrocks decomposition of total inequality (see Annex 1). The sum of each row in this panel is normalised to 100 (except for "transfers and taxes" column, which is the sum of the two previous columns), so an entry in a row can be interpreted as the percentage contribution of that component to total inequality. The middle panel shows the shares of each component in disposable income ${ }^{16}$. The right-hand panel is the left-hand panel divided by the middle panel, which can be interpreted as the marginal increase in the contribution to inequality of an income component as that component's share in disposable income rises ${ }^{17}$.

[Table 3.3. Contributions of income components to total inequality: Shorrocks decomposition]

36. For all countries except Belgium and Italy, labour income was by far the major contributor to overall inequality; indeed, except for the same two countries, labour earnings accounted for more than 100 per cent of total inequality. By contrast, again with the exception of Belgium and Italy, capital and self-employment income made a much smaller contribution. This difference reflects the fact that labour earnings were a much larger share of total income than capital and self-employment income (middle panel), although the inaccuracy of measuring capital and self-employment earnings may also be important. In most countries, capital and self-employment income was more unevenly distributed than labour income, and its marginal impact on inequality was therefore greater (right-hand panel). Because of its importance, a change in the distribution of earnings would strongly affect the distribution of disposable income.

37. Taken together, taxes and transfers diminished inequality in all countries. The contribution of transfers to inequality was negative in all but three countries but, where it had a negative impact, was relatively small compared to that of taxes. This reflects the fairly even distribution of transfers across income groups (see Table 3.1); by definition, with the Shorrocks decomposition, any income component that is equally distributed across individuals makes a contribution of zero to inequality. It is worth emphasising, however, that a small or zero contribution (in the Shorrocks sense) to inequality does not

16. Note that taxes are given a negative "share", but that negative changes in the share of taxes implies increased tax pressure.

17. Note that the sign of each entry in the right-hand panel is determined exclusively by the sign of the corresponding entry in the left-hand panel, and not by the usual arithmetic rules; a positive number in the change rows indicates an increase in the contribution to inequality, except for taxes where a positive sign indicates an increase in the equalising effect. 
imply that transfers were not redistributive in the usual sense ${ }^{18}$. On the contrary, because market incomes were in fact unevenly distributed, transfers had an equalising effect on disposable income (see Box C).

38. Table 3.3 also shows changes in the Shorrocks contributions. These are due to a combination of changes in the share of each component in disposable income (shown also in the middle panel) and the effect of changes in the intrinsic inequality of the component (right-hand panel). Thus, if a component that contributed to overall inequality became a larger share of disposable income, or if it becomes more unequally distributed over time, then the contribution of the component to total inequality would rise, all else equal. Changes in the entries in the right-hand panel are changes in the contribution to inequality purged of the effects of share shifts; in other words, those due to changes in the inequality of the component itself.

39. Because the Shorrocks decomposition is independent of any particular inequality index, these breakdowns do not show how income components have accounted for changes in indices of inequality of disposable income over time. This issue can be examined, however, by applying the Shorrocks percentage shares to an index of inequality. The results are shown in Table 3.4 for the SCV index ${ }^{19}$.

\section{[Table 3.4. Decomposition of changes in total inequality: SCV]}

40. Total inequality as measured by the SCV rose in all countries except Germany. In principle, this could have been due either to increases in the share of disposable income of components that contribute to inequality, or to a wider distribution within any component. As indicated by the third column of the table, in most countries, the major factor was the increased contribution to inequality of labour earnings, by far the largest component of disposable income (except in Belgium, Finland and Italy, where capital and self-employment income were dominant, as indicated in the sixth column, and in Sweden where transfers were dominant). In general, however, earnings did not become substantially larger as a fraction of disposable income, and in many countries the impact of the changing share was to reduce inequality (the first column of the table). The increased contribution was due instead to rising inequality within earnings (the second column of the table); in Germany, falling earnings inequality contributed to falling inequality in disposable income. In general, capital and self-employment income did not have a big impact on changes in total inequality, except in Finland and Italy, where the data indicate that this component became considerably more unevenly distributed over time.

41. Both taxes and transfers became somewhat more effective over time in equalising disposable incomes in most countries, Italy, Japan and Sweden being the major exceptions for transfers and Germany for taxes. For transfers, often the most important factor was an increase in the importance of transfers in disposable income, reflecting, in some countries, rising transfer expenditures over time, rather than an increasing shift in transfers towards those with low incomes. In several countries (Italy, Japan, Sweden and the United States), transfers became more equally spread across incomes, implying that an additional dollar had less of an equalising effect over time. Indeed, in Italy, Sweden and the United States the reduction in the equalising effect of transfers mainly reflected changes to the transfer systems themselves, rather than reductions in their overall size. The equalising effect of taxes also generally rose over time, except in Germany where it fell. Tax pressure rose in most countries, which increased the overall equalising effect, whereas the change in the equalising effect of taxes excluding the tax pressure effect varied from country to country. However, one should be cautious in interpreting these results: the SCV

18. That is, that they raised incomes at the bottom of the distribution.

19. If the component increases (reduces) inequality it has a positive (negative) sign. 
does not always move in parallel with other indices and the contributions can vary depending on the size and sign of the changes in the overall index used.

\section{Changes in well-being for groups of the population}

42. This section groups individuals according to certain characteristics of the households to which they belong. A primary objective is to identify both the groups which have gained or lost as well as some of the reasons why this has occurred. An important focus is given to work attachment, as measured by the number of household members in employment, as a determinant of the relative position of individuals, both at a given point in time and for changes over the period. A second objective is to examine changes in the structure of the population across these different groups, and to highlight their importance for aggregate movements in income distribution, particularly those relating to shifts in the degree of work attachment, using a decomposition of the Mean Log Deviation index.

43. As described in more detail in Annex 1, the data are presented on the basis of three sets of household characteristics:

- work attachment of households, distinguishing between three groups: households with two or more wage-earners, households with only one wage-earner, and households with no member in employment;

- age of the household head, distinguishing between four groups: young head (with a household head below 30 years of age); prime-age head (between 30 and 50 years of age); older working-age head (between 50 and 65 years of age); and retirement-age head (above 65 years of age $)^{20}$;

- family type: this refers to the number of adults in the household (single-adult and two-or-more-adult households) and, within each group, between households with and without children ${ }^{21}$.

Individuals are also grouped by work attachment and demographic characteristics, thus permitting a more detailed analysis for specific groups of policy interest. The data refer to the relative position of individuals, who are attributed the equivalent income of their households (see Box A). Thus, for example, a reference to earnings means equivalent household earned income from dependent employment earned by the household, as attributed to the individuals in that household and adjusted for household "economies of scale". Changes in equivalent income of each group may be affected by changes in both the total income received by the household to which they belong and household size, both of which enter into the calculation of equivalent income.

20. Data were also broken down on the basis of the age of the individual, as opposed to the age of the household head. This isolates specific groups, such as children or the elderly. Some key results are reported in Section 4.5 .

21. The term "family" is used only for expositional convenience. For most countries, the data refer to a broader concept of "household", where the persons in the household are not necessarily related by marriage or blood (see Box A). 
ECO/WKP(98)2

\subsection{Main results}

44. The main points emerging from this analysis are the following:

- Individuals in households with no wage-earners had lower-than-average incomes, as did those in households with a young head and with children (either one or two adults). Persons in households with a head of retirement age also had below-average income, although this may understate their relative position in terms of consumption possibilities, since they generally have higher stocks of assets than other age groups.

- Changes over time in the incomes of various groups relative to the overall average tended to be small compared with the differences in levels at a point in time. Such changes were, however, closely linked to changes in patterns of earnings and employment.

- Shifts in earnings among the working-age households were not fully offset by taxes and transfers. Older-worker and retirement-age households benefited the most from transfers, reflecting maturing pension schemes. Increases in inequality, as measured by the MLD, appear to be associated with a rise in the numbers of individuals living in households with no member at work.

\subsection{Levels and changes in relative incomes of sub-groups of the population}

45. Employment is the most obvious determinant of relative disposable income. Table 4.1 presents equivalent disposable incomes relative to the population average, grouped according to the degree of work attachment of the household to which individuals belong, for the end year and the total change over the period $^{22}$ To abstract, as far as possible, from trends in retirement age, the data refer to individuals in households with a head below 65 years old. Not surprisingly, in all countries, individuals in households with no-one at work had the lowest average equivalent disposable income, followed by those in households with one worker and then with two workers. The change in relative incomes over time tended to be small compared with the differences across groups at a point of time and there were no clear patterns across countries.

\section{[Table 4.1. Relative disposable income, by degree of work attachment of households]}

46. Table 4.2 shows relative income by age of the household head. In terms of levels, equivalent disposable incomes tend to rise with age of the head until retirement approaches and to decline thereafter $^{23}$. Changes in relative income by age over the past two decades were somewhat more marked than those for work attachment, with young households experiencing stability or declines, while older working-age, retirement-age and, to a lesser degree, prime-age households generally improved their

22. Averages have been calculated for the later period using the population weights of the beginning period to avoid distortions arising from changing shares of groups in the population.

23. This pattern is even more pronounced when individuals are grouped according to their age, rather than by age of household head. Current disposable income, as measured in household surveys, is however a very poor indicator of the economic resources available to the elderly in retirement, given that many accumulate wealth before retirement. 
relative position. These movements imply a steepening of the relative income/age (up to retirement age) curve in most cases ${ }^{24}$.

\section{[Table 4.2. Relative disposable income, by age of the household head]}

47. A similar analysis is presented in Table 4.3 for individuals belonging to households with one or more adults and with and without children. Although sensitive to the equivalence scale used, single-adult households with children had the lowest disposable income (with the exception of Finland), followed by single adults without children, two-adult households with children and two-adult households without children. This may reflect household age, as single-adult households without children are likely to be young or very old, and two-earner households are likely to be in peak earning years. There is little consistent pattern in changes over time across countries, although declines were more frequent among single-adult households with and without children.

\section{[Table 4.3. Relative disposable income, by family type]}

\subsection{Accounting for changes in relative income of sub-groups of the population}

48. While relative incomes often changed little over time, there were a number of common trends in income components. The contributions of earnings, capital and self-employment income, transfers and taxes to changes in relative incomes of the various household groups are shown in Figures 4.1 to 4.3. The dotted line shows the (relative) income change over the period for each group, while the elements within the bars indicate the contributions of each income component to this change. For example, the black portion of the first bar in Figure 4.1 shows how capital and self-employment earnings contributed to changes in the relative income position of households with no worker ${ }^{25}$.

49. Looking first at income sources across work-attachment categories, the dominant contribution of taxes and transfers is evident for households with no worker (Figure 4.1), often associated with offsetting capital and self-employment income. By contrast, the effect of earnings is more visible among households with one or more workers, often with larger positive contributions for double wage-earner households in Australia, Denmark, Japan and the United States, and negative contributions for households with a single wage-earner in Australia, Finland, Sweden and the United States.

\section{[Figure 4.1. Contribution of different income components to changes in relative income, by work attachment of households]}

50. Across household groups, market income and particularly earnings also appear to have contributed the most to shifts in the relative position of the various groups. In general, the contribution of

24. Since household size is correlated with the age of the household head, levels of relative income by age of the household head are especially sensitive to the equivalence scale used, although this is less the case for changes over time (see Annex 2).

25. The dotted line is the per cent change in the relative income of the specific household type (i.e. the ratio of the average disposable income of the household type relative to the population average). The contributions of various income sources for a specific group was calculated as follows: $i$ ) for a given household type, the growth rate of each component of income was calculated; ii) this growth rate was then expressed as a ratio of the growth rate of average disposable income (of the population); and iii) the resulting relative growth rate was then weighted by the importance of each income component in the disposable income of the household type. For each household type the sum of the contributions is equal to the growth rate of relative income (the dotted line). The complete formula is found in Annex 1, Section 7. 
earnings growth tended to be weak or negative for households with young and retirement-age heads, but stronger or positive for prime-age and older working-age heads, although there are important exceptions to this pattern (Figure 4.2) ${ }^{26}$. Labour-market trends were also important for households with children (Figure 4.3). In the case of single-adult households with children, earnings were the main factor for the increase in relative income of this group in the United States. Earnings had a negative impact in all other countries for this group, contributing to declines in disposable incomes in Australia, Denmark, France, Germany, Italy and Sweden. In Italy and Sweden, the fall in relative income among this group was largely employment-related, as the share of non-working households increased among single-adult households with children. The opposite trend appeared in the Netherlands and the United States and, in the latter, there was strong growth in the earnings of working single-adult households with children as well.

\section{[Figure 4.2. Contribution of different income components to changes in relative income, by age of the household head]}

\section{[Figure 4.3. Contribution of different income components to changes in relative income, by family type]}

51. Lower earnings were partially offset by income transfers, but there was considerable variation across countries and household types. With the exceptions of Australia, Finland, Germany and the Netherlands, retirement-age and, to a lesser degree, older working-age households benefited most from income transfers ${ }^{27}$. This positive contribution of public transfers mainly reflected retirement trends and therefore lower employment in these groups. These trends may not be independent in that improved retirement benefits have induced early retirement decisions; indeed, in some countries this has been an explicit policy goal. For other household categories, there were few clear patterns across countries.

\subsection{Factors affecting earnings across household types}

52. The contribution of earnings to changes in relative income of the various demographic groups can be broken down into:

- An earnings effect: within each household group, this is measured as the (weighted sum of) changes in earned income per capita for each work-attachment category (two or more workers, one worker, no worker $)^{28}$.

- An employment effect: for each household group, this is measured as the (weighted sum of) changes in its shares of the three work-attachment categories. For example, this could take

26. Similar results emerge when the data are broken down by the age of individuals, rather than the age of the head of household.

27. In both Finland and the Netherlands, the negative contribution of public transfers was compensated by a positive contribution of capital and self-employment income, possibly associated with the increased importance of occupational pension arrangements.

28. Relative earnings refer to the level of earned income per capita of each work-attachment category (two or more earners; one earners; zero earners) relative to the population average within each demographic group. The work-attachment of households generally refers to employment. In some countries, households with zero wage-earners did report positive earnings, possibly reflecting differences between the time period used for assessing income (annual income) and for defining the working status of family members (at the time the survey was made). 
the form of increased polarisation of employment opportunities for a specific group, with a larger share of persons in households with no wage-earner and in households with two or more workers.

53. The relative importance of the earnings and employment effects can be seen by comparing the experience of households with a young head with those with an older working-age head (Table 4.4). Earnings contributed to a relative decline in the incomes of households with a young head (negative values in the first column of Table 4.4, top panel) in all countries except Germany. Negative values in the second column of Table 4.4 imply that, for most countries, this was due to falls in earned income per capita for each of the different work-attachment categories among households with a young head relative to other groups. This negative effect was compounded by a negative "employment effect" in most countries, associated with higher unemployment, increased school attendance and, in some cases, a decline of the proportion of young households in households with two or more workers (Sweden) ${ }^{29}$. The major exceptions were the United States and, to a lesser extent, Japan, where both higher employment rates and an increased share of two-earner households raised earnings of households with a young head.

\section{[Table 4.4. Contribution of earnings and employment to changes in earnings: young and older-worker households]}

54. This contrasts with the experience of households with an older working-age head shown in the bottom panel of Table 4.4, where a generalised negative "employment effect" (third column, bottom panel) was associated with a positive "earnings effect" (second column, bottom panel). The negative "employment effect" reflects a generalised trend to earlier retirement and declines in the labour-force participation of older workers. The "earnings effect", however, was positive for this group. This is consistent with the view that high-earnings heads tended preferentially to remain in employment, as their opportunity cost of retirement was higher. This change in mix would raise average earnings of the group. The same effect may have partly accounted for the positive "earnings effect" for prime-age and retirement-age households in several countries (not shown).

55. There were also significant differences between single-parent and two-parent households, both with children (Table 4.5). The former experienced declines in the contribution of earned income in most countries (first column, top panel), while the opposite occurred for two-parent households (first column, bottom panel). In a majority of countries, the negative contribution of earnings for single parents reflected a combination of falls in relative earnings in each work-attachment group (second column, top panel) and shifts towards households with no member at work. In Japan, the Netherlands and the United States, however, increased employment opportunities (a positive "employment effect") led to a positive contribution from earnings to the income of single-parent households. In the United States, this positive effect was further strengthened by higher relative earnings within each work-attachment group.

\section{[Table 4.5. Contribution of earnings and employment to changes in earnings: households with children]}

\subsection{Developments for population groups of special policy interest}

56. This section examines groups that appear to be of particular policy interest in many countries in a way which cuts across the broad categories in the preceding section.

29. The data do not allow, however, the separation of the importance of changes in hours worked from changes in relative earnings of those with full-time jobs. 
57. Members of households with no workers but with heads of working age had disposable income well below average (Table 4.6). Within this group, relative incomes tended to rise with the age of the household head, reflecting mainly larger transfers, but also income from capital and self-employment. Over time, there were no clear trends except for older workers where an improvement in their relative position was more prevalent (Figure 4.4).

\section{[Table 4.6. Relative disposable incomes of non-working households]}

[Figure 4.4. Contribution of different income components to changes in relative disposable income: non-working households]

58. Most OECD countries have transfer programmes specifically targeted to households with children. Child poverty is recognised as particularly undesirable, as it may negatively affect children's life chances, and children have little or no means of supporting themselves outside the family. In most countries, equivalent disposable income of those in households with children were below average, but typically within 10 per cent of the average (Table 4.7, first column) ${ }^{30}$. There was, however, a widespread decline in children's incomes over time, but typically less than 5 per cent (Canada excepted). Also, working single-adult households with children generally had lower relative incomes than two-adult single-earner households with children, with the exception of Finland (Table 4.7, right-hand panel). This probably reflects the predominance of female heads (who earn less than male heads) in the former group.

\section{[Table 4.7. Relative disposable incomes of children, the elderly and single earners with children]}

59. While there are no consistent patterns across countries in movements in relative incomes over time, there were declines in both single and two-parent households with children in a significant number of countries. Figure 4.5, shows the contributions of income components to these changes and suggests that there were fairly widespread declines in the contribution of earnings in both household types but that this was replaced to varying degrees by transfers. Despite the higher levels of income than among singleadult households, transfers to two-adult households appear to have increased more. In the United States: earnings for single-adult households increased sharply, possibly reflecting the strength of the labour market and a narrowing between earnings of men and women, whereas earnings appear to have declined sharply for two-adult one-earner households.

[Figure 4.5. Contribution of income components to changes in relative disposable income: children and single-earner households with children]

60. Older individuals (second and third columns of Table 4.7) and retired households (middle panel of Table 4.7) also had disposable incomes below average, although their relative position improved in most countries $^{31}$. Transfers have been an important positive effect in about half of the countries (Figure 4.6). In several other countries there were increases in capital and self-employment income.

[Figure 4.6. Contribution of income components to changes in relative disposable income: the retired non-working households with head over 65]

30. Relative incomes of children are sensitive to the equivalence scale used and would be lower if no household economies of scale were assumed.

31. Canada and the Netherlands are exceptions. In the Netherlands the decline in the relative position was sharper for individuals above 75. These groups appear be more dependent on the state pension and, as these declined over the 1980s, their relative income fell. The age group between 65 and 75 appears to have increasingly benefited from private pension arrangements. 


\subsection{Relative incomes and changing work attachment and household structure: the impact on income distribution}

61. This section links the changes in relative incomes of individual groups just described and changes in population structure to overall change in income inequality described in Chapter 2 . It first looks at some of the more important shifts in population groups and work attachment and then examines the importance of these changes for the overall development of inequality.

62. Changes in the population structure and employment status across OECD countries have, in some cases, resulted in growing importance of groups with lower relative incomes. Table 4.8 shows the sharp increase in the shares of households with no earner, reflecting both increased retirement and higher unemployment among those of working age. Across household types, the most important change affecting the distribution of income was the increase in the share of single-adult households with children, because this group had incomes considerably lower than average (Table 4.3) ${ }^{32}$. There was also an increase in the share of households without children, reflecting both population ageing and delays in family formation and childbearing, possibly due to the more difficult economic situation of the young. Population ageing (Table 4.8) led to a rise in households with retirement-age heads and a fall in the share of households with younger heads, but the effects of these developments on inequality were partially offsetting because both groups had lower-than-average incomes.

\section{[Table 4.8. Population structure by work attachment and household type]}

63. The importance of movements in income between groups and changes in their shares in the population can be clarified using a decomposition of the Mean Log Deviation (MLD) index introduced in Chapter 2. This index can be separated additively into:

- A component due to differences in average incomes between groups. This "between-group" component is the sum of the relative incomes of the various groups (in log form) weighted by their share in the total population. Changes in this "between-group" component of the MLD highlight to what extent aggregate trends in income distribution have been driven by larger differences in the well-being between individuals grouped by some key characteristics.

- A component due to inequality within each individual group. This "within-group" effect is the sum of the MLD index (i.e. the degree of inequality) specific to each group, once again weighted by their population shares.

64. Table 4.9 shows the MLD and its two components for the latest period and the change on the basis of a breakdown of the population by work attachment (two-worker, one-worker and no-worker households). The change in the between-group component was positive in all countries except Denmark and Sweden, but the within-group effect was dominant, although negative for Denmark and France. The generalised widening in the earnings distribution (see Chapter 3) appears to have been reflected in greater income inequality within groups with different degrees of work attachment rather than on average incomes of these groups.

\section{[Table 4.9. Changes in inequality: between-group and within-group effects]}

32. The net impact of this change was a sharp fall in average household size, particularly so in the Netherlands. This has no necessary implications for the distribution of income, but to some extent household economies of scale were lost. 
65. Table 4.10 provides a further detail regarding the contributions of the three factors (within, between and structural effects) to the total change in the MLD over time. The results differ from those found in Table 4.9, where the effects of the changes in population shares are hidden in the between- and within-group effects. For example, a shift from one-worker to no-worker households will increase aggregate inequality by increasing the weight of low income in the total (increase in the between-group effect in Table 4.9) and because the income dispersion with non-worker households is greater than for one-worker households (increase in the within-group effect). Table 4.10 uses a shift-share analysis to distinguish between:

- "Pure" within- and between-group effects: i.e. the change in the overall MLD arising from i) changes in average income between groups; and ii) changes in the within-group MLD, in both cases with the population shares held constant.

- Structural effects: i.e. the change in the overall MLD arising from changes in the share of each group in the total population. This takes into account the change in average incomes and in the overall within-group MLD as individuals move from one household type to another.

\section{[Table 4.10. Decomposition of the changes in MLD by work attachment]}

66. While there is considerable variation in the patterns across countries, data in the first four columns of Table 4.10 confirm that the "pure" within-group effect is the dominant factor explaining the overall change in income distribution for most countries and these increases (next three columns) were widespread among all employment status groups although less prevalent among no-worker households. Structural effects (column 4 and last three columns) are largely positive indicating that the shifts in population shares have led to an overall widening in the distribution and, within this, the impact of the increase in the share of non-workers was large and positive. Finally, the negative between-group effect for non-worker households for most countries suggests that the rise in their relative incomes -- as noted in Section 4.3 -- has partially offset the impact of the increasing share of non-workers on the overall increase in inequality.

\section{Poverty and low income}

\subsection{Introduction and main results}

67. This chapter considers trends in poverty over the past two decades, both at the aggregate level and for individual groups. Section 5.2 presents different measures of poverty, and Section 5.3 describes aggregate trends using these measures. Sections 5.4 and 5.5 present detailed analyses of the changing pattern of poverty for individuals grouped by work attachment and household characteristics. This is done using two poverty indicators. Section 5.4 presents data on the share of individuals within each group that falls in the bottom quintile, based on the questionnaire. Clearly, this indicator cannot be used to assess the degree of overall poverty (it would be one-fifth by construction) but it can shed light on the groups especially vulnerable to poverty. Section 5.5 presents data on poverty rates, drawn from the Luxembourg Income Study at the level of both market and disposable income, allowing an assessment of the effectiveness of taxes and transfers in reducing poverty. The poverty threshold, is in this case, defined in a standard way as 50 per cent of median equivalent disposable income.

68. The main findings are as follows: 
- Poverty appears to have increased at an aggregate level in half of the countries considered. Some of the sharpest increases in poverty occurred in Europe, rather than in the United States. With the exception of the United States, the increase of poverty, where it occurred, was mainly concentrated in the 1980s.

- Looking at the bottom quintile, the risk of poverty and low incomes was particularly high among non-working households of working age, households with a retired head (although to a lesser degree) and, in some countries, certain categories of single-earner households. Risks of low income generally fell for non-worker households -- particularly the retired -- but increased for certain categories of working households.

- Data for five countries from the Luxembourg Income Study (LIS) point to an increase in poverty at the level of market income in four of them ${ }^{33}$. The tax and transfer system has been effective in reducing poverty in all countries, especially for households with an older head. The make-up of the poor has tended to shift over time from the old to the young, from households with no children to households with children, and from households not working to households who are working.

\subsection{Aggregate trends in poverty}

69. This section examines three measures of poverty and how they have changed over time. The first is the share of individuals with incomes falling below the poverty line (the head-count ratio). The poverty lines are here defined as 40, 50 or 60 per cent of median equivalent disposable income, with most emphasis placed on the 50 per cent poverty line. The second is the difference between the average income of the poor and the poverty line (the average income gap). The third is a composite measure, the Sen index, which combines the first two measures with an index of the dispersion of income (the Gini coefficient) among the poor. (See Annex 1, Section 5.2 for further details.)

70. Changes in the Sen index (and in the head-count ratio) over the entire period and for the period from the mid-1980s to the mid-1990s show that poverty (based on a 50 per cent threshold) increased in seven of the thirteen countries (Table 5.1). Among countries experiencing an increase in poverty, the rise was mainly concentrated in the most recent decade; poverty fell in the United States only in the most recent period, although this fall did not offset the increase in the previous decade. For the period as a whole, poverty appears to have fallen in Belgium, Denmark and France (where income dispersion probably declined), in Australia and Canada (despite broad stability in overall inequality), and in Finland (despite a widening of the income distribution).

71. The movements in the income gap suggest how average incomes have changed among the poor relative to the economy-wide median (a positive value indicates a widening in the gap and a fall in average incomes of the poor relative to the median) ${ }^{34}$. Except for Australia and the Netherlands and, to a lesser degree, Norway and the United States, this indicator follows the head count. For Australia, the decline in the headcount at the 50 per cent threshold and a rise at the 60 per cent threshold suggests a bunching of the individuals between the 50 per cent and the 60 per cent thresholds. For the Netherlands, even though the head-count ratio increased, those in poverty were better off relative to the median. At the

33. The five countries are Canada, France, Germany, the Netherlands and Sweden.

34. Note that the average income gap is defined relative to the poverty line which is, in turn, a fixed proportion of the median. 
same time, average incomes in the bottom quintile (individuals with incomes less than 65 per cent of the median in 1994) fell over the period (both in absolute and relative terms) suggesting that those below the poverty threshold fared better than other low-income groups.

\section{[Table 5.1. Trends in poverty using a relative threshold: mid-1970s to mid-1990s]}

72. In most countries, median income rose in real terms over the past 20 years, and with it the poverty threshold used in Table $5.1^{35}$. When using a "constant" threshold, defined in terms of real median income in the earliest year, poverty fell in most countries (see Table 5.2) or increased less rapidly than poverty in relative terms (Table 5.1). Australia is an exception: median equivalent income fell over the period and "constant" poverty, therefore, increased.

[Table 5.2. Trends in poverty using a constant threshold: mid-1970s to mid-1990s]

\subsection{Poverty rates and the structure of poverty (individuals in the bottom quintile)}

73. Poverty affected the various demographic groups with different intensity. This section presents data on individuals grouped by work attachment and the household characteristics used in Chapter 4, for twelve of the thirteen countries covered in the questionnaire. The poverty indicator is the share of individuals in each specific group which fall into the bottom quintile of the income distribution. The poverty "threshold" implicit in this measure varies over time and across countries. For the United States, for example, it was 52 per cent of median income in 1979 and 57 per cent in 1995. In the mid-1990s it was 72 per cent in Sweden, reflecting a narrower distribution of income than in the United States. In interpreting results, it should be remembered that, since the fraction of individuals in the bottom quintile is constant, a rise in the importance of one group in the total implies falls in other groups, and that results for certain groups are especially sensitive to assumptions about household economies of scale. Further, for some disaggregated categories the total number of poor in the sample is often small, and posing an increased risk of sampling error, irrespective of the measure used.

74. Two dimensions of poverty are presented in Table 5.3 for selected groups which are generally considered to have a high risk of poverty. The poverty rate (first column) shows "who is exposed to the risk of poverty". The structure of poverty is the proportion of individuals in the bottom quintile belonging to a given group (second column); this shows "who the poor are". These measures differ because the size of the various population sub-groups varies substantially. Thus, a group with a high poverty rate might account for only a small share of total poverty if it is only a small fraction of the total population.

\section{[Table 5.3. Poverty rates and poverty structure after taxes and transfers]}

75. Although sensitive to assumptions about economies of scale, the risk of poverty was especially high for individuals in a household with no household member at work, although this was less the case for households with a non-working head above 65 (the retired). Risks of poverty were also high in some countries for households with a single earner, especially for single-adult households with children and households with a young head.

35. Some recent reports have claimed that the CPI indices used to deflate incomes may have been biased upwards. To this degree, real incomes may have risen faster and poverty, using a poverty threshold constant in real terms, may have declined or risen more slowly than shown here. 
76. Looking at changes over time, among the higher-risk groups, the risk of poverty fell most sharply and most consistently across countries for the retirement-age households. For other groups, the declines were less prevalent particularly for non-working two-adult households with children. Among the working population, the risk of poverty increased in the majority of countries for single adults with children and for households with a young head.

77. Canada and Japan excepted, 70 per cent or more of the poor belonged to either non-working or single-earner households. With unemployment on the rise, certain groups which experienced a decline in the risk of poverty made up an increasing share of the poor: for example, non-working households, particularly those with a young head, and with children. The increase in share of one-worker single-adult households with children in the population also contributed to an increase in the share of this group among the poor, while the declining population share of one-worker two-adult households with children has had the opposite effect.

\subsection{The effect of taxes and transfers in reducing poverty in selected population groups: an analysis of five OECD countries}

78. In this section, head-count ratios are computed for five countries (Canada, France, Germany, Sweden and the United States) based on data from the Luxembourg Income Study. In both cases, the poverty threshold is 50 per cent of median disposable income. Both pre- and post-tax and transfer poverty rates are examined, thus permitting an analysis of the effect of taxes and transfers on poverty. Apart from overall poverty rates, this section focuses on the experience of several population groups: these are defined in terms of the age of the household head; presence of children in the household; and whether the household had employed members.

79. Poverty and its evolution depend on both market incomes and taxes and transfers, with transfers being particularly important at the bottom end of the income scale. However, these two factors are not independent. Changes in the distribution of market incomes affect poverty rates, leading to changes in tax-transfer programmes. Conversely, tax-transfer programmes can affect the distribution of market incomes, notably by affecting the choice of how much to work. Nevertheless, information on the role of the tax-transfer system in shaping poverty can be obtained by comparing poverty in terms of market incomes (before taxes and transfers) with that in terms of disposable incomes (after taxes and transfers).

80. This comparison is made in two ways: a comparison of poverty rates before and after taxes and transfers shows how the risk of poverty has been affected; and a comparison of the structure of poverty shows how tax-transfer systems have changed the composition of the poor. As explained above, the difference between these two measures reflects the varying demographic sizes of the groups.

81. In the mid-1990s, the incidence of market-income poverty -- measured as the number of individuals with equivalent market disposable incomes less than 50 per cent of median disposable income -- differed sharply across groups (Table 5.4). Obviously, those not employed had the highest poverty rates, with single-adult, non-working households being especially notable. Households with a head above 65 also had relatively high poverty rates, in large part because most of them were also retired, non-working households. Households with a young head (less than 30 years old) had poverty rates that exceeded the total poverty rate in Canada, Sweden and the United States, but were below it in France and Germany. This may reflect the life-cycle effect -- young households generally have young workers with little experience and who therefore received relatively low labour income. High minimum wages in France (and the apprenticeship system in Germany) may have moderated this factor in those countries. 


\section{[Table 5.4. Poverty rates before taxes and transfers]}

82. All countries experienced a rise in aggregate poverty rates at the level of market income, although the rise in Canada was negligible. The increase was widespread though individuals in old households experienced a reduction in market-related poverty rates in all countries except Germany, where the rate was broadly unchanged ${ }^{36}$. In Canada, Germany and the United States, households without children also experienced declining poverty rates, reflecting in part the fact that many of them were also old households.

83. The structure of poverty differed substantially from its incidence, reflecting the demographic importance of each group (Table 5.5). To take an extreme example, non-working single-adult households with children had among the highest poverty rates, but the percentage of all those in poverty drawn from this group was relatively low because it was a relatively small group -- in the mid-1990s, between 1 and 2.2 per cent of the total population in the five countries (Table 5.6).

\section{[Table 5.5. Structure of poverty before taxes and transfers]}

[Table 5.6. Population structure]

84. Examining the changes in the structure of poverty, those from older working-age and retirement-age households formed a smaller fraction of the poor in the mid-1990s than earlier, except in France (retirement-age) and Germany (older-worker) where their importance was broadly unchanged. Those from young and prime-age households accounted for a somewhat larger fraction of the poor, although which age group contributed the most varied across countries. And households with children became a substantially larger fraction of the poor in Canada and Sweden, and a slightly larger fraction in France and the United States. Otherwise, the structure of poverty did not change in a consistent manner across countries.

85. Tables 5.7 and 5.8 present, respectively, poverty rates and the structure of poverty for the same groups as in Tables 5.4 and 5.5, using the same poverty line (50 per cent of median equivalent disposable income). Incomes, however, are equivalent disposable incomes -- that is, after taxes and transfers -- rather than market incomes. A comparison of the two sets of tables provides information about the extent to which tax-transfer systems have mitigated poverty in terms of market incomes, and how such effects have evolved over time. As already mentioned, care must be taken in interpreting such a comparison, because market incomes react to tax-transfer systems. That is, Tables 5.7 and 5.8 do not necessarily represent what poverty rates and structures (in terms of disposable income) would be in the absence of tax-transfer systems (and likewise Tables 5.4 and 5.5 do not necessarily represent poverty rates and structures of market income in the absence of taxes and transfers).

\section{[Table 5.7. Poverty rates after taxes and transfers] [Table 5.8. Structure of poverty after taxes and transfers]}

86. The effect of taxes and transfers has been to reduce poverty substantially in all five countries, by amounts ranging from more than 25 percentage points in France and Sweden to around 5 percentage points in the United States in the mid-1990s (comparing Tables 5.5 and 5.7). The most marked change was the reduction of poverty rates of those in households with heads older than 65 years from the highest of all groups before taxes and transfers to, in some countries, among the lowest after taxes and transfers.

36. Additional decompositions suggest that capital income is becoming increasingly concentrated among the elderly. 
By contrast, in terms of disposable income, individuals in households with young heads had the highest poverty rates in four of the five countries (France excepted), and the positive impact of taxes and transfers in reducing poverty was much less important for this group. This situation reflects the impact of large and growing social security programmes in all countries, which have indeed proved successful in their goal of dramatically reducing poverty among the old.

87. As might be expected, poverty rates among non-working households were also sharply reduced by taxes and transfers. However, non-working households with heads younger than 65 (which excludes most, though not all, pension recipients) still had among the highest poverty rates. Again, among nonworking households, the poverty rate was especially high among single-adult households with children (except in Sweden), though tax-transfer system reduced poverty in this group as well. Among all households with children, tax-transfer systems worked to reduce poverty rates, although in Canada and the United States this group had a lower poverty rate than the total population in terms of market income, and a higher rate in terms of disposable income.

88. Turning to the structure of poverty, in all countries those in households with retirement-age heads formed a much smaller fraction of the poor after taxes and transfers than before (Table 5.8 compared with Table 5.5). By contrast, both those in households with heads below 65 years old (particularly non-working households) and (except in Sweden) those in households with children represented a larger fraction of the poor after tax and transfers than before. That is, in terms of the structure of poverty, the tax-transfer system shifted poverty from the old to the young and, to some extent, households with children. There was an increase in the share of poor among workers as well.

89. Looking over time, poverty rose at the level of market incomes (Table 5.4), but the tax-transfer systems succeeded in reducing or roughly holding constant poverty in terms of disposable incomes in four of the five countries (not the United States) (Table 5.7). After-tax-and-transfer poverty rates for the elderly fell particularly sharply. At the same time, in all five countries poverty rates rose for many groups -- particularly those in households headed by the young and in households with children ${ }^{37}$.

90. The structure of poverty has changed over time as well. Those in households with a head over 65 formed a declining fraction of those in poverty, both before taxes and transfers (except in France) and, especially, after taxes and transfers. By contrast, households with working-age heads formed a rising fraction of the poor whether they worked or not (except for France and the United States where nonworkers fell) and, again, these results held for poverty both before and after taxes and transfers. These patterns cannot in general be accounted for by changes in population structure (Table 5.6) except for, to some extent, the rising share of the poor accounted for by those in households with heads aged 30 to 50 (the baby boom).

91. The incidence and structure of poverty in the mid-1990s suggests directions that reforms might take. While social policy has typically pursued a variety of objectives, poverty relief is one of them. Expanding transfers would probably further reduce poverty rates generally. However, there may be limits to this process. Table 5.9 compares transfers per capita and total poverty rates for Canada, Sweden and the United States. While countries with higher public transfers reduced poverty rates, the reduction per dollar tended to fall as expenditures rose. Moreover, despite the substantial increase in public transfers to households since the mid-1970s, in all countries, notably in Sweden, poverty rates fell only in Canada.

\section{[Table 5.9. Reduction of poverty due to taxes and transfers]}

37. Recall, however, that the poverty concept here is a relative one, and that therefore the absolute living standards of those in poverty may have risen over time. 


\section{ECO/WKP(98)2}

92. Without further analysis, which is beyond the scope of this paper, it is impossible to say why this is so. In Sweden, for example, public transfers tended to be widely spread across social groups and much money therefore went to persons not in poverty. While this greatly increased the costs of the programmes, universalistic welfare programmes have helped to reduce marginal effective tax rates and the attendant risk of "poverty traps". Moreover, because the benefits of transfer programmes were widely spread over the population, they enjoyed a broad base of political support. However, the expansion of transfer programmes have had diminishing effects on poverty rates because those who remained in poverty were increasingly hard to reach. This may have been because it was difficult to design programmes targeted to them, or because of concerns that more generous transfers to certain groups -- those of working age, for example -- might reduce work effort.

93. There is arguably room for a refocusing of transfers. In particular, the position of the old has improved dramatically due to both higher (though still relatively low) market incomes and larger transfers. In some countries, pension and other retirement plans have led to a decline in retirement ages, and delaying the age at which people become eligible for pensions will probably be an important component of reforms to put pension plans on a sustainable footing. Finally, in countries such as Sweden, with large, broadly-based programmes, it may be possible to reduce overall outlays without having a large adverse effect on poverty at the margin. 
Table 2.1. Trends in inequality indices ${ }^{1}$

ECO/WKP(98)2

Equivalence scale elasticity $=0.5$

\begin{tabular}{|c|c|c|c|c|c|c|c|c|c|c|}
\hline & \multicolumn{10}{|c|}{$\begin{array}{l}\text { Mid-1970s to mid-1990s } \\
\text { Inequality indicators }\end{array}$} \\
\hline & \multicolumn{2}{|c|}{ Gini levels } & \multicolumn{2}{|c|}{\begin{tabular}{|c|} 
Gini \\
\end{tabular}} & \multicolumn{2}{|c|}{ SCV } & \multicolumn{2}{|c|}{ MLD } & \multicolumn{2}{|c|}{\begin{tabular}{|c|} 
Atkinson \\
\end{tabular}} \\
\hline & Initial level & Final level & Relative chan & Absolute change & Relative chang & Absolute change & Relative chang & Absolute change & Relative change & Absolute change \\
\hline Australia, 1975/76-1993/94 & 29.1 & 30.6 & 5.2 & 1.5 & 14.7 & 4.8 & 13.1 & 2.1 & 11.6 & 0.8 \\
\hline Belgium & .. & .. & .. & .. & .. & .. & .. & .. & .. & .. \\
\hline Canada, 1975-1994 & 28.3 & 28.4 & 0.2 & 0.1 & 7.8 & 2.2 & -5.8 & -0.9 & .. & .. \\
\hline Denmark & .. & .. & .. & .. & .. & .. & .. & .. & .. & .. \\
\hline Finland & .. & .. & .. & .. & .. & .. & .. & .. & .. & .. \\
\hline France & .. & .. & .. & .. & .. & .. & .. & .. & .. & .. \\
\hline Germany & .. & .. & .. & .. & .. & .. & .. & .. & .. & .. \\
\hline Italy & .. & .. & .. & .. & .. & .. & .. & .. & .. & .. \\
\hline Japan & .. & .. & .. &.. & . &.. &.. & 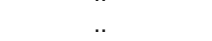 &.. &.. \\
\hline Netherlands, 1977-1994 & 22.6 & 25.3 & 11.8 & 2.7 & 20.2 & 4.0 & 29.8 & 2.7 & 25.4 & 1.1 \\
\hline Norway & .. & 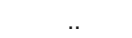 & & .. & & & .. & & 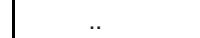 & \\
\hline Sweden, 1975-1995 & 23.2 & 23.0 & -1.0 & -0.2 & 36.9 & 5.8 & 2.1 & 0.2 & 3.2 & 0.2 \\
\hline \multirow[t]{4}{*}{ United States, 1974-1995 } & 31.3 & 34.4 & 10.0 & 3.1 & 25.4 & 8.9 & 20.3 & 3.7 & 18.6 & 1.6 \\
\hline & \multicolumn{10}{|c|}{$\begin{array}{l}\text { Mid-1980s to mid-1990s } \\
\text { Inequality indicators }\end{array}$} \\
\hline & \multicolumn{2}{|c|}{ Gini levels } & \multicolumn{2}{|c|}{ Gini } & \multicolumn{2}{|c|}{ SCV } & \multicolumn{2}{|c|}{ MLD } & \multicolumn{2}{|c|}{ Atkinson } \\
\hline & Initial level & Final level & Relative chan & Absolute change & Relative chang & Absolute change & Relative chang & Absolute change & Relative change & Absolute change \\
\hline Australia, 1984-1993/94 & 31.2 & 30.6 & -1.9 & -0.6 & 4.5 & 1.6 & 1.4 & 0.3 & -0.8 & -0.1 \\
\hline Belgium, 1983-1995 & 25.9 & 27.2 & 4.7 & 1.2 & 28.2 & 9.1 & 2.8 & 0.4 & 7.1 & 0.4 \\
\hline Canada, 1985-1994 & 28.9 & 28.4 & -1.9 & -0.6 & -17.5 & -6.6 & -6.8 & -1.0 & .. & .. \\
\hline Denmark, 1983-1994 & 22.9 & 21.7 & -4.9 & -1.1 & 2.0 & 0.4 & -14.3 & -1.5 & -11.1 & -0.5 \\
\hline Finland, 1986-1995 & 21.2 & 23.1 & 9.1 & 1.9 & 47.7 & 7.8 & 14.8 & 1.2 & 20.0 & 0.7 \\
\hline France, 1979-1990 & 29.6 & 29.1 & -1.7 & -0.5 & 2.1 & 1.3 & -13.6 & -4.7 & -3.0 & -0.2 \\
\hline Germany, 1984-1994 & 26.5 & 28.2 & 6.4 & 1.7 & -6.3 & -2.2 & 13.0 & 1.6 & 29.9 & 2.0 \\
\hline Italy, 1984-1993 & 30.6 & 34.5 & 12.7 & 3.9 & 44.7 & 18.0 & 41.2 & 7.0 & 32.7 & 2.6 \\
\hline Japan, 1984-1994 & 25.2 & 26.5 & 4.9 & 1.2 & 21.7 & 5.3 & 13.5 & 1.5 & 10.9 & 0.6 \\
\hline Netherlands, 1985-1994 & 23.4 & 25.3 & 8.2 & 1.9 & 6.0 & 1.4 & 21.3 & 2.0 & 17.9 & 0.8 \\
\hline Norway, 1986-1995 & 23.4 & 25.6 & 9.4 & 2.2 & 8.1 & 2.3 & 31.1 & 3.1 & .. & .. \\
\hline Sweden, 1983-1995 & 21.6 & 23.0 & 6.5 & 1.4 & 58.9 & 8.0 & 23.0 & 2.1 & 20.6 & 0.8 \\
\hline United States, 1985-1995 & 34.0 & 34.4 & 1.1 & 0.4 & 2.9 & 1.2 & 2.4 & 0.5 & 2.0 & 0.2 \\
\hline
\end{tabular}

1. Indices have been multiplied by 100 . Absolute change is the difference in the value of the index. Source: OECD. 


\section{Table 2.2. Overall trends in income distribution: summary results from national studies}

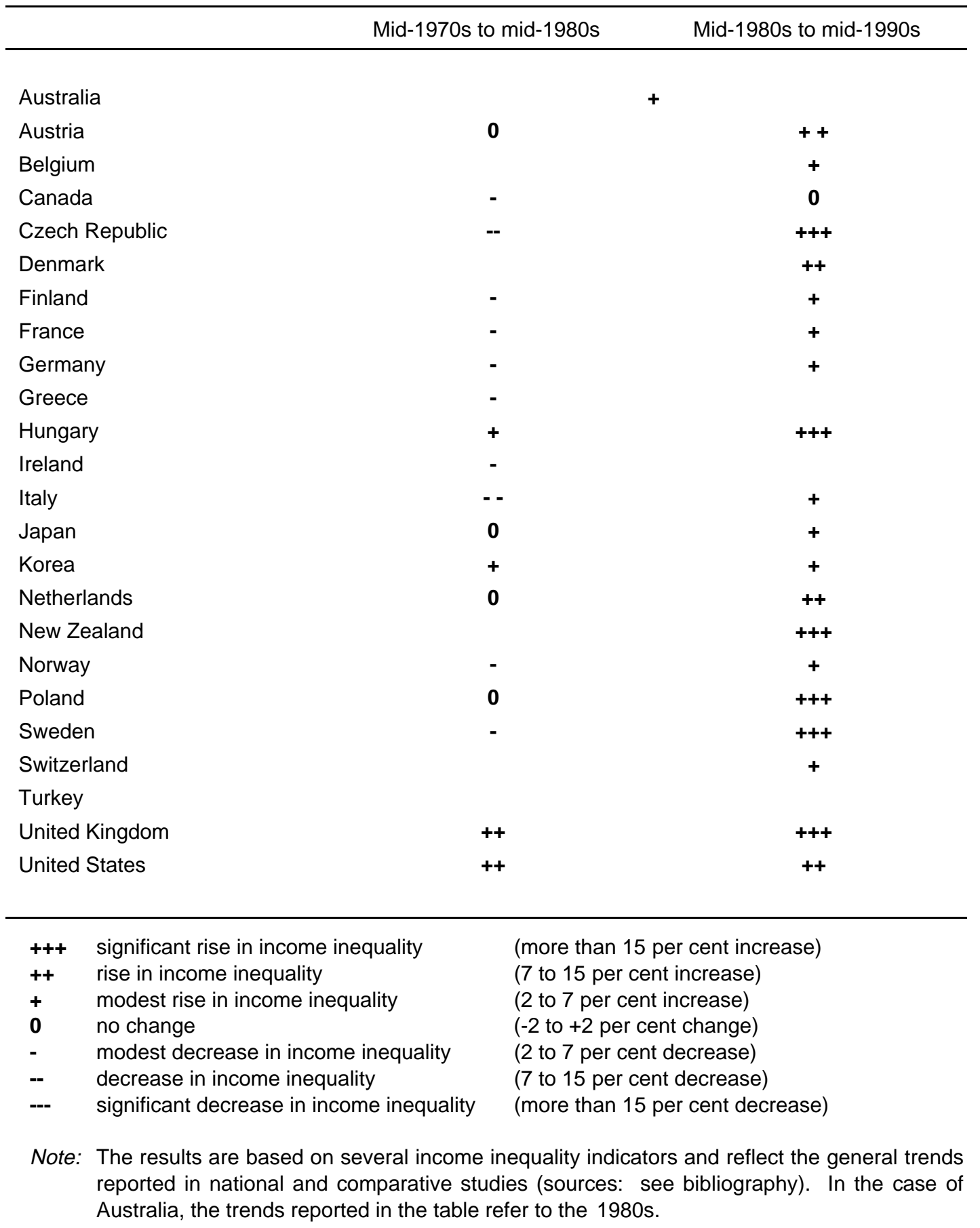




\section{Table 3.1. Allocation of income components across decile groups}

Equivalence scale elasticity $=0.5$

Per cent, and changes in percentage points

\begin{tabular}{|c|c|c|c|c|c|c|c|c|c|c|c|c|c|c|c|c|c|c|}
\hline & \multicolumn{3}{|c|}{ Earnings } & \multicolumn{3}{|c|}{$\begin{array}{l}\text { Capital and self- } \\
\text { employment income }\end{array}$} & \multicolumn{3}{|c|}{ Market income } & \multicolumn{3}{|c|}{$\begin{array}{c}\text { General government } \\
\text { transfers } \\
\end{array}$} & \multicolumn{3}{|c|}{ Taxes } & \multicolumn{3}{|c|}{ Total disposable income } \\
\hline & $\begin{array}{c}\text { three } \\
\text { bottom } \\
\text { deciles }\end{array}$ & $\begin{array}{c}\text { four } \\
\text { middle } \\
\text { deciles }\end{array}$ & $\begin{array}{c}\text { three } \\
\text { top } \\
\text { deciles }\end{array}$ & $\begin{array}{l}\text { three } \\
\text { bottom } \\
\text { deciles }\end{array}$ & $\begin{array}{c}\text { four } \\
\text { middle } \\
\text { deciles }\end{array}$ & $\begin{array}{c}\text { three } \\
\text { top } \\
\text { deciles }\end{array}$ & $\begin{array}{c}\text { three } \\
\text { bottom } \\
\text { deciles }\end{array}$ & $\begin{array}{c}\text { four } \\
\text { middle } \\
\text { deciles }\end{array}$ & $\begin{array}{c}\text { three } \\
\text { top } \\
\text { deciles }\end{array}$ & $\begin{array}{l}\text { three } \\
\text { bottom } \\
\text { deciles }\end{array}$ & $\begin{array}{c}\text { four } \\
\text { middle } \\
\text { deciles }\end{array}$ & $\begin{array}{c}\text { three } \\
\text { top } \\
\text { deciles }\end{array}$ & $\begin{array}{c}\text { three } \\
\text { bottom } \\
\text { deciles }\end{array}$ & $\begin{array}{c}\text { four } \\
\text { middle } \\
\text { deciles }\end{array}$ & $\begin{array}{c}\text { three } \\
\text { top } \\
\text { deciles }\end{array}$ & \begin{tabular}{|c|} 
three \\
bottom \\
deciles \\
\end{tabular} & $\begin{array}{c}\text { four } \\
\text { middle } \\
\text { deciles }\end{array}$ & $\begin{array}{c}\text { three } \\
\text { top } \\
\text { deciles }\end{array}$ \\
\hline Australia, 1993/94 & 3.5 & 33.5 & 63.0 & 10.6 & 33.9 & 55.5 & 4.7 & 33.6 & 61.7 & 58.0 & 34.6 & 7.4 & 1.9 & 27.8 & 70.4 & 13.8 & 35.1 & 51.1 \\
\hline Changes, 1975-1994 & -5.8 & -4.2 & 10.1 & -8.5 & 3.4 & 5.2 & -6.5 & -2.8 & 9.2 & 1.1 & 5.2 & -6.3 & -7.9 & -6.0 & 13.9 & -0.4 & -1.0 & 1.4 \\
\hline Belgium, 1995 & 5.9 & 36.5 & 57.6 & 5.8 & 16.3 & 77.9 & 5.9 & 31.8 & 62.4 & 33.7 & 43.1 & 23.3 & 2.8 & 30.1 & 67.2 & 15.7 & 36.0 & 48.3 \\
\hline Changes, 1983-1995 & 0.0 & 0.2 & -0.3 & -3.1 & -6.3 & 9.5 & -0.6 & -1.6 & 2.3 & 0.4 & 0.7 & -1.2 & -1.3 & 0.7 & 0.6 & 0.3 & -1.6 & 1.3 \\
\hline Canada, 1994 & 5.6 & 32.9 & 61.5 & 9.0 & 36.9 & 54.1 & 6.0 & 33.4 & 60.6 & 41.7 & 41.0 & 17.3 & 2.9 & 29.2 & 67.9 & 14.0 & 35.9 & 50.1 \\
\hline Changes, 1975 - 1994 & -0.5 & -3.5 & 4.1 & -7.2 & 2.7 & 4.5 & -1.0 & -2.9 & 3.8 & -7.6 & 7.2 & 0.4 & -0.7 & -2.0 & 2.7 & 1.2 & -0.9 & -0.4 \\
\hline Denmark, 1994 & 6.7 & 38.7 & 54.6 & 14.4 & 30.8 & 54.8 & 7.8 & 37.6 & 54.6 & 45.8 & 37.5 & 16.7 & 12.7 & 36.5 & 50.8 & 17.6 & 38.2 & 44.2 \\
\hline Changes, 1983 - 1994 & -1.0 & -0.9 & 1.9 & -5.8 & -3.9 & 9.6 & -2.0 & -1.2 & 3.2 & 3.8 & -1.1 & -2.7 & 2.1 & -3.0 & 0.9 & 0.8 & -0.2 & -0.6 \\
\hline Finland, 1995 & 6.3 & 36.1 & 57.6 & 20.0 & 32.3 & 47.8 & 10.2 & 35.0 & 54.8 & 39.8 & 41.4 & 18.7 & 9.5 & 32.9 & 57.6 & 17.5 & 37.2 & 45.3 \\
\hline Changes, 1986 - 1995 & -3.4 & -2.0 & 5.4 & -3.2 & -1.4 & 4.5 & -1.8 & -2.3 & 4.1 & 2.4 & 4.4 & -6.8 & 0.3 & -1.1 & 0.8 & -0.6 & -1.2 & 1.7 \\
\hline France, 1990 & .. & .. & .. & .. & .. & .. & .. & .. & .. & .. & .. & .. & .. & .. & .. & .. & .. & .. \\
\hline Changes, 1979-1990 & .. & .. & .. & .. & .. & .. & .. & .. & .. & .. & .. & .. & .. & .. & .. & .. & .. & .. \\
\hline
\end{tabular}


ECO/WKP(98)2

Table 3.1 (continued)

\begin{tabular}{|c|c|c|c|c|c|c|c|c|c|c|c|c|c|c|c|c|c|c|}
\hline & \multicolumn{3}{|c|}{ Earnings } & \multicolumn{3}{|c|}{$\begin{array}{l}\text { Capital and self- } \\
\text { employment income }\end{array}$} & \multicolumn{3}{|c|}{ Market income } & \multicolumn{3}{|c|}{$\begin{array}{c}\text { General government } \\
\text { transfers }\end{array}$} & \multicolumn{3}{|c|}{ Taxes } & \multicolumn{3}{|c|}{ Total disposable income } \\
\hline & $\begin{array}{c}\text { three } \\
\text { bottom } \\
\text { deciles }\end{array}$ & $\begin{array}{c}\text { four } \\
\text { middle } \\
\text { deciles }\end{array}$ & $\begin{array}{c}\text { three } \\
\text { top } \\
\text { deciles }\end{array}$ & $\begin{array}{c}\text { three } \\
\text { bottom } \\
\text { deciles }\end{array}$ & $\begin{array}{c}\text { four } \\
\text { middle } \\
\text { deciles }\end{array}$ & $\begin{array}{c}\text { three } \\
\text { top } \\
\text { deciles }\end{array}$ & $\begin{array}{c}\text { three } \\
\text { bottom } \\
\text { deciles }\end{array}$ & $\begin{array}{c}\text { four } \\
\text { middle } \\
\text { deciles }\end{array}$ & $\begin{array}{c}\text { three } \\
\text { top } \\
\text { deciles }\end{array}$ & $\begin{array}{l}\text { three } \\
\text { bottom } \\
\text { deciles }\end{array}$ & $\begin{array}{c}\text { four } \\
\text { middle } \\
\text { deciles }\end{array}$ & $\begin{array}{c}\text { three } \\
\text { top } \\
\text { deciles }\end{array}$ & $\begin{array}{c}\text { three } \\
\text { bottom } \\
\text { deciles }\end{array}$ & $\begin{array}{c}\text { four } \\
\text { middle } \\
\text { deciles }\end{array}$ & $\begin{array}{c}\text { three } \\
\text { top } \\
\text { deciles }\end{array}$ & $\begin{array}{l}\text { three } \\
\text { bottom } \\
\text { deciles }\end{array}$ & $\begin{array}{c}\text { four } \\
\text { middle } \\
\text { deciles }\end{array}$ & $\begin{array}{c}\text { three } \\
\text { top } \\
\text { deciles }\end{array}$ \\
\hline Germany, 1994 & 7.5 & 34.6 & 57.8 & 11.0 & 31.3 & 57.7 & 8.0 & 34.2 & 57.8 & 38.6 & 40.1 & 21.3 & 5.3 & 31.7 & 62.9 & 14.8 & 36.1 & 49.1 \\
\hline Changes, 1984 - 1994 & -0.2 & -0.8 & 1.0 & -1.5 & 0.7 & 0.8 & -0.2 & -0.8 & 1.0 & -5.0 & 4.9 & 0.1 & -0.5 & 0.4 & 0.1 & -1.1 & -0.1 & 1.2 \\
\hline Italy, 1993 & 9.3 & 35.4 & 55.3 & 5.6 & 20.0 & 74.5 & 8.1 & 30.6 & 61.3 & 20.8 & 44.7 & 34.5 & 5.8 & 29.8 & 64.4 & 12.1 & 34.4 & 53.5 \\
\hline Changes, 1984 - 1993 & -3.1 & -2.2 & 5.3 & -2.2 & -2.5 & 4.6 & -2.8 & -2.3 & 5.1 & -5.8 & 0.8 & 5.1 & -4.8 & -2.3 & 7.1 & -1.9 & -0.7 & 2.6 \\
\hline Japan, 1994 & 13.0 & 36.5 & 50.5 & 17.8 & 27.5 & 54.7 & 13.7 & 35.1 & 51.2 & 27.5 & 37.5 & 35.0 & 11.3 & 29.7 & 59.0 & 15.7 & 36.5 & 47.8 \\
\hline Changes, 1984-1994 & 1.1 & -1.1 & -0.1 & -5.5 & -3.8 & 9.4 & -1.2 & -0.8 & 2.0 & -0.5 & 4.8 & -4.2 & -1.3 & -1.2 & 2.4 & -0.6 & -0.2 & 0.8 \\
\hline Netherlands, 1994 & 8.3 & 37.6 & 54.2 & 8.8 & 30.3 & 61.0 & 8.4 & 36.3 & 55.4 & 43.6 & 35.7 & 20.7 & 10.7 & 34.5 & 54.7 & 16.2 & 36.8 & 47.0 \\
\hline Changes, 1977 - 1994 & -5.7 & 0.2 & 5.5 & -0.1 & 5.0 & -4.9 & -4.7 & 1.1 & 3.6 & 10.0 & -2.5 & -7.5 & -2.2 & 0.7 & 1.5 & -1.6 & 0.4 & 1.2 \\
\hline Norway, 1995 & 8.7 & 40.8 & 50.5 & 9.5 & 22.8 & 67.7 & 8.8 & 37.0 & 54.2 & 47.7 & 35.3 & 17.0 & 8.3 & 35.4 & 56.3 & 16.0 & 37.2 & 46.8 \\
\hline Changes, 1986-1995 & -3.1 & -0.2 & 3.4 & -0.8 & -2.6 & 3.4 & -2.6 & -0.8 & 3.5 & 2.3 & -0.9 & -1.4 & -1.8 & -2.4 & 4.2 & -1.0 & -0.4 & 1.4 \\
\hline Sweden, 1995 & 7.2 & 35.5 & 57.2 & 17.3 & 28.8 & 53.9 & 8.0 & 35.0 & 57.0 & 31.4 & 41.4 & 27.2 & 10.7 & 34.8 & 54.4 & 17.2 & 37.9 & 44.9 \\
\hline Changes, 1975 - 1995 & -0.2 & -1.8 & 2.1 & -2.1 & -6.6 & 8.7 & -0.5 & -2.2 & 2.7 & -8.3 & 5.9 & 2.4 & 3.5 & 1.2 & -4.7 & 0.3 & -0.1 & $\begin{array}{c}- \\
-0.2\end{array}$ \\
\hline United States, 1995 & 7.6 & 33.9 & 58.5 & 7.5 & 26.8 & 65.7 & 7.6 & 32.8 & 59.6 & 37.2 & 38.2 & 24.6 & 5.2 & 26.5 & 68.2 & 11.5 & 35.0 & 53.5 \\
\hline Changes, 1974 - 1995 & -1.1 & -3.3 & 4.4 & -1.6 & 1.0 & 0.6 & -1.2 & -2.6 & 3.8 & -6.8 & 3.8 & 3.0 & 0.3 & -3.7 & 3.5 & -1.2 & -1.4 & 2.6 \\
\hline
\end{tabular}

Note: See Annex 1, Section 6 for the methodology.

Source OECD. 
Table 3.2. Aggregate inequality indicators before and after taxes and transfers

ECO/WKP(98)2

Equivalence scale elasticity $=0.5$

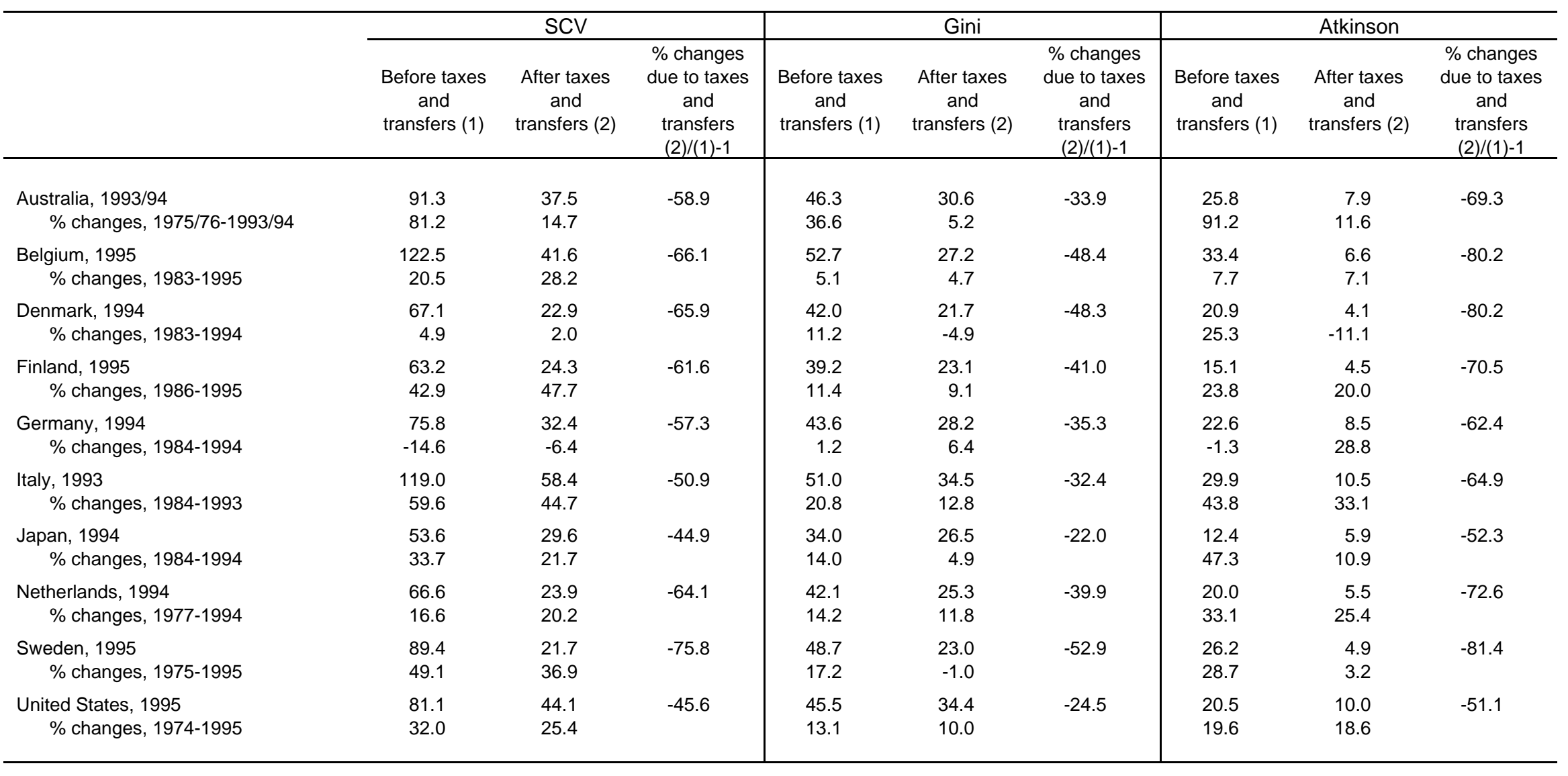

Source: OECD. 
Table 3.3. Contribution of income components to total inequality: Shorrocks decomposition

Equivalence scale elasticity $=0.5$

\begin{tabular}{|c|c|c|c|c|c|c|c|c|c|c|c|c|c|}
\hline \multicolumn{14}{|c|}{ Per cent, and changes in percentage points } \\
\hline & \multicolumn{5}{|c|}{ Percentage contribution to total inequality of disposable income (1) } & \multicolumn{4}{|c|}{ Percentage shares (2) } & \multicolumn{4}{|c|}{ Relative inequality indicator $(1) /(2)$} \\
\hline & Earnings & $\begin{array}{c}\text { Capital and self- } \\
\text { employment }\end{array}$ & Transfers & Taxes & $\begin{array}{c}\text { Transfers and } \\
\text { taxes } \\
\end{array}$ & Earnings & $\begin{array}{c}\text { Capital and self- } \\
\text { employment }\end{array}$ & Transfers & Taxes & Earnings & $\begin{array}{c}\text { Capital and self- } \\
\text { employment }\end{array}$ & Transfers & Taxes \\
\hline Australia, 1975/76 & 85.2 & 40.3 & -5.5 & -20.1 & -25.5 & 82.0 & 19.4 & 6.3 & -7.7 & 1.04 & 2.07 & -0.87 & 2.62 \\
\hline Australia, 1993/94 & 123.8 & 39.6 & -13.5 & -49.8 & -63.4 & 88.7 & 18.8 & 15.7 & -23.2 & 1.40 & 2.11 & -0.86 & 2.15 \\
\hline Changes, 1975-1994 & 38.6 & -0.7 & -8.1 & -29.8 & -37.9 & 6.7 & -0.6 & 9.4 & -15.5 & 0.36 & 0.03 & 0.01 & -0.47 \\
\hline Belgium, 1983 & 79.6 & 81.8 & -3.0 & -58.5 & -61.4 & 82.4 & 22.0 & 30.5 & -34.9 & 0.97 & 3.72 & -0.10 & 1.67 \\
\hline Belgium, 1995 & 66.4 & 94.4 & -3.4 & -57.4 & -60.8 & 81.1 & 24.8 & 31.4 & -37.3 & 0.82 & 3.80 & -0.11 & 1.54 \\
\hline Changes, 1983-1995 & -13.2 & 12.6 & -0.4 & 1.0 & 0.6 & -1.3 & 2.8 & 0.9 & -2.4 & -0.15 & 0.08 & -0.01 & -0.14 \\
\hline Denmark, 1983 & 120.3 & 56.2 & -11.4 & -65.1 & -76.5 & 103.7 & 20.2 & 23.2 & -47.1 & 1.16 & 2.78 & -0.49 & 1.38 \\
\hline Denmark, 1994 & 134.2 & 49.3 & -19.3 & -64.3 & -83.5 & 105.3 & 16.5 & 33.1 & -54.8 & 1.27 & 3.00 & -0.58 & 1.17 \\
\hline Changes, 1975-1994 & 13.9 & -6.9 & -7.9 & 0.8 & -7.0 & 1.6 & -3.8 & 9.9 & -7.7 & 0.11 & 0.22 & -0.09 & -0.21 \\
\hline Finland, 1986 & 137.2 & 33.4 & -5.0 & -65.6 & -70.6 & 95.7 & 19.8 & 19.6 & -35.2 & 1.43 & 1.69 & -0.25 & 1.87 \\
\hline Finland, 1995 & 101.8 & 66.2 & -11.3 & -56.7 & -68.0 & 78.8 & 31.3 & 23.7 & -33.7 & 1.29 & 2.12 & -0.48 & 1.68 \\
\hline Changes, 1975-1995 & -35.4 & 32.8 & -6.3 & 8.9 & 2.6 & -16.9 & 11.5 & 4.1 & 1.4 & -0.14 & 0.43 & -0.22 & -0.19 \\
\hline Germany, 1984 & 135.5 & 15.0 & 6.4 & -56.9 & -50.5 & 100.7 & 10.4 & 19.9 & -31.0 & 1.35 & 1.44 & 0.32 & 1.83 \\
\hline Germany, 1994 & 115.9 & 29.9 & 0.6 & -46.4 & -45.8 & 94.6 & 15.2 & 19.8 & -29.6 & 1.22 & 1.96 & 0.03 & 1.56 \\
\hline Changes, 1975-1994 & -19.6 & 14.9 & -5.8 & 10.6 & 4.8 & -6.1 & 4.8 & -0.1 & 1.4 & -0.12 & 0.52 & -0.29 & -0.27 \\
\hline Italy, 1984 & 51.1 & 87.6 & 0.3 & -39.0 & -38.7 & 76.2 & 34.1 & 18.4 & -28.7 & 0.67 & 2.57 & 0.01 & 1.36 \\
\hline Italy, 1993 & 41.4 & 95.4 & 4.3 & -41.1 & -36.8 & 72.1 & 32.3 & 25.4 & -29.8 & 0.57 & 2.96 & 0.17 & 1.38 \\
\hline Changes, 1975-1994 & -9.7 & 7.8 & 4.1 & -2.2 & 1.9 & -4.1 & -1.8 & 7.0 & -1.1 & -0.10 & 0.39 & 0.16 & 0.02 \\
\hline Japan, 1984 & 94.1 & 41.2 & 2.6 & -37.9 & -35.3 & 82.5 & 30.8 & 6.7 & -20.0 & 1.14 & 1.34 & 0.38 & 1.89 \\
\hline Japan, 1994 & 94.8 & 41.8 & 4.3 & -40.9 & -36.6 & 93.0 & 16.8 & 10.8 & -20.6 & 1.02 & 2.49 & 0.40 & 1.99 \\
\hline Changes, 1984-1994 & 0.7 & 0.6 & 1.7 & -3.0 & -1.3 & 10.5 & -14.0 & 4.1 & -0.5 & -0.12 & 1.15 & 0.01 & 0.10 \\
\hline Netherlands, 1977 & 111.5 & 68.2 & -3.6 & -76.0 & -79.6 & 102.0 & 22.2 & 22.4 & -46.6 & 1.09 & 3.07 & -0.16 & 1.63 \\
\hline Netherlands, 1994 & 131.1 & 45.4 & -12.5 & -63.9 & -76.4 & 95.3 & 20.8 & 24.9 & -41.0 & 1.38 & 2.18 & -0.50 & 1.56 \\
\hline Changes, 1975-1994 & 19.6 & -22.8 & -8.9 & 12.1 & 3.2 & -6.7 & -1.4 & 2.4 & 5.6 & 0.28 & -0.89 & -0.34 & -0.07 \\
\hline Norway, 1986 &.. &.. &.. &.. &.. &.. &.. &.. &.. &.. &.. &.. & .. \\
\hline Norway, 1995 & .. & .. & .. & .. & .. & .. & .. & .. & .. & .. & .. & .. & .. \\
\hline Changes 1975-1994 &.. & .. &.. &.. & .. & .. &.. & .. &.. &.. &.. &.. &.. \\
\hline Sweden, 1975 & 173.5 & 23.3 & -14.0 & -82.8 & -96.8 & 97.9 & 9.8 & 25.5 & -33.1 & 1.77 & 2.37 & -0.55 & 2.50 \\
\hline Sweden, 1995 & 138.3 & 26.5 & 4.7 & -69.5 & -64.8 & 90.1 & 7.8 & 43.9 & -41.8 & 1.53 & 3.39 & 0.11 & 1.66 \\
\hline Changes, 1975-1994 & -35.3 & 3.2 & 18.7 & 13.4 & 32.1 & -7.8 & -2.0 & 18.5 & -8.7 & -0.24 & 1.01 & 0.66 & -0.84 \\
\hline United States, 1974 & 102.6 & 40.3 & -3.3 & -39.5 & -42.9 & 95.0 & 18.7 & 8.7 & -22.3 & 1.08 & 2.16 & -0.38 & 1.77 \\
\hline United States, 1995 & 109.4 & 36.4 & -1.4 & -44.4 & -45.8 & 97.1 & 18.8 & 11.0 & -26.9 & 1.13 & 1.94 & -0.13 & 1.65 \\
\hline Changes, $1975-1994$ & 6.8 & -3.8 & 1.9 & -4.8 & -2.9 & 2.1 & 0.1 & 2.3 & -4.5 & 0.05 & -0.22 & 0.25 & -0.12 \\
\hline
\end{tabular}

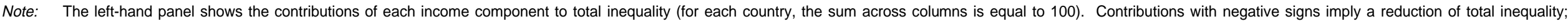
negative changes in contributions (third row) indicate a stronger equalising effect (or a weaker de-equalising effect). The central panel shows shares of income components in disposable income. The shares of taxes appear with a negative sign, and a negative change implies an increase in tax burden. The right-hand panel shows contributions of each component to inequality divided by its share in total income and express a "pure" equalising effect of each component. In general, a negative sign indicates that the component (e.g. transfers) is reducing inequality, and a negative change increases this equalising effect. However, in the case of taxes a positive sign implies a reduction of inequality and a positive change increases the equalising effect.

Source: OECD. 
Table 3.4. Decomposition of changes in total inequality: SCV

$\mathrm{ECO} / \mathrm{WKP}(98) 2$

Equivalence scale elasticity $=0.5$

Absolute change ${ }^{1}$

\begin{tabular}{|c|c|c|c|c|c|c|c|c|c|c|c|c|c|c|c|}
\hline & \multicolumn{3}{|c|}{ Earnings } & \multicolumn{3}{|c|}{$\begin{array}{l}\text { Capital and self-employment } \\
\text { income }\end{array}$} & \multicolumn{3}{|c|}{ Transfers } & \multicolumn{3}{|c|}{ Taxes } & \multicolumn{3}{|c|}{ Total change in SCV } \\
\hline & \multicolumn{2}{|c|}{ Part due to change in: } & \multirow[b]{2}{*}{$\begin{array}{c}\text { Total } \\
(1)+(2)\end{array}$} & \multicolumn{2}{|c|}{ Part due to change in: } & \multirow[b]{2}{*}{$\begin{array}{l}\text { Total } \\
(3)+(4)\end{array}$} & \multicolumn{2}{|c|}{ Part due to change in: } & \multirow[b]{2}{*}{$\begin{array}{l}\text { Total } \\
(5)+(6)\end{array}$} & \multicolumn{2}{|c|}{ Part due to change in: } & \multirow[b]{2}{*}{$\begin{array}{l}\text { Total } \\
(7)+(8)\end{array}$} & \multicolumn{2}{|c|}{ Part due to change in: } & \multirow[b]{2}{*}{ Tota } \\
\hline & $\begin{array}{c}\text { Shares }^{2} \\
\text { (1) }\end{array}$ & $\begin{array}{l}\text { Component } \\
\text { inequality }^{3} \\
\text { (2) }\end{array}$ & & $\begin{array}{l}\text { Shares }^{2} \\
\text { (3) }\end{array}$ & $\begin{array}{c}\text { Component } \\
\text { inequality }^{3} \\
\text { (4) }\end{array}$ & & $\begin{array}{c}\text { Shares }^{2} \\
(5)\end{array}$ & $\begin{array}{c}\text { Component } \\
\text { inequality }{ }^{3} \\
(6)\end{array}$ & & $\begin{array}{c}\text { Shares }^{2} \\
(7)\end{array}$ & $\begin{array}{c}\text { Component } \\
\text { inequality }^{3} \\
\text { (8) }\end{array}$ & & Shares $^{2}$ & $\begin{array}{l}\text { Component } \\
\text { inequality }^{3}\end{array}$ & \\
\hline Australia, 1975/76-1993/94 & 2.9 & 15.6 & 18.5 & -0.5 & 2.1 & 1.6 & -2.9 & -0.4 & -3.3 & -12.9 & 0.8 & -12.1 & -13.3 & 18.1 & 4.8 \\
\hline Belgium, 1983-1995 & -0.4 & 2.2 & 1.8 & 4.0 & 8.8 & 12.7 & 0.0 & -0.4 & -0.5 & -1.4 & -3.5 & -4.9 & 2.1 & 7.1 & 9.1 \\
\hline Denmark, 1983-1994 & 0.4 & 3.3 & 3.7 & -2.5 & 1.1 & -1.3 & -1.2 & -0.6 & -1.9 & -2.2 & 2.1 & -0.1 & -5.5 & 5.9 & 0.4 \\
\hline Finland, 1986-1995 & -4.7 & 6.8 & 2.2 & 4.5 & 6.1 & 10.6 & -0.3 & -1.6 & -1.9 & 0.5 & -3.5 & -3.0 & 0.1 & 7.8 & 7.8 \\
\hline Germany, 1984-1994 & -2.6 & -6.7 & -9.3 & 2.7 & 1.8 & 4.5 & 0.0 & -2.0 & -2.0 & 0.8 & 3.9 & 4.7 & 0.9 & -3.1 & -2.2 \\
\hline Italy, 1984-1993 & -1.2 & 4.8 & 3.6 & -2.6 & 22.9 & 20.4 & 0.4 & 2.1 & 2.4 & -0.8 & -7.6 & -8.3 & -4.2 & 22.2 & 18.0 \\
\hline Japan, 1984-1994 & 3.0 & 2.1 & 5.2 & -7.4 & 9.8 & 2.4 & 0.4 & 0.2 & 0.6 & -0.3 & -2.6 & -2.9 & -4.3 & 9.5 & 5.3 \\
\hline Netherlands, 1977-1994 & -1.8 & 11.0 & 9.2 & -0.8 & -1.9 & -2.7 & -0.2 & -2.1 & -2.3 & 2.0 & -2.1 & -0.2 & -0.8 & 4.9 & 4.0 \\
\hline Norway, 1986-1995 & .. & .. & .. & .. & .. & .. & .. & .. & .. & .. & .. & .. & .. & .. & .. \\
\hline Sweden, 1975-1995 & -2.4 & 4.9 & 2.5 & -1.1 & 3.2 & 2.0 & -0.6 & 3.8 & 3.2 & -3.3 & 1.3 & -1.9 & -7.4 & 13.2 & 5.8 \\
\hline United States, 1974-1995 & 0.9 & 11.2 & 12.2 & 0.1 & 1.8 & 1.9 & -0.2 & 0.8 & 0.5 & -3.1 & -2.6 & -5.7 & -2.3 & 11.2 & 8.9 \\
\hline
\end{tabular}

1. Absolute change is the difference in the value of the SCV index.

2. Change in SCV due to changes in the share of each component in total income. Where the sign is negative, inequality is reduced.

3. Change in SCV arising from widening or narrowing in the distribution within each component.

Note: This table combines information from Table 2.1 (inequality indices) and Table 3.3. To obtain the contributions of each component (columns marked "Total") to the overall SCV change (last column), the SCV index for each year was first multiplied by the contributions in the left-hand panel of Table 3.3 and the difference between the two years was calculated for each income source. (Note that it is possible to have a positive change between two years in the contribution of a component in Table 3.3 (e.g. a weaker de-equalising effect) and a negative contribution to the overall change in the SCV in this table (e.g. taxes in Finland). A numerical example to illustrate this is shown in Annex 1, Section 6). For the further breakdown into that part arising from the part due to "changes in shares" and part due to "changes in component inequality", the SCV contribution of each component was broken into two parts in each period: $\mathrm{SCV}_{i}=\mathrm{SH}_{\mathrm{i}}^{*}\left(\mathrm{SCV} / \mathrm{SH}_{i}\right)$ where SCV is the SCV contribution of the ith component, $\mathrm{SH}_{i}$ is its share in total income (see Table 3.3, middle panel). The second term is analogous to that found in the right-hand panel of Table 4.3. A shift share calculation -- i.e. the change in the contribution from the change in first term when the second is held constant and vice versa -- was then applied.

Source: OECD 
Table 4.1. Relative disposable income, by degree of work attachment of households

Equivalence scale elasticity $=0.5$

Population in households with a working-age head

\begin{tabular}{|c|c|c|c|c|}
\hline & & No worker & One worker & Two workers \\
\hline \multirow[t]{3}{*}{ Australia } & Level 1993/94 & 45.4 & 79.9 & 121.3 \\
\hline & $\%$ change, $1975 / 76-1993 / 94$ & 8.2 & 3.0 & -1.8 \\
\hline & Percentage point change & 3.4 & 2.4 & -2.2 \\
\hline \multirow[t]{3}{*}{ Belgium } & Level 1995 & .. &.. & .. \\
\hline & $\%$ change, 1983-1995 & .. & .. & .. \\
\hline & Percentage point change &.. & .. & .. \\
\hline \multirow[t]{3}{*}{ Denmark } & Level 1994 & 67.0 & 84.8 & 111.9 \\
\hline & $\%$ change, $1983-1994$ & 2.9 & 1.4 & -0.7 \\
\hline & Percentage point change & 1.9 & 1.2 & -0.8 \\
\hline \multirow[t]{3}{*}{ Finland } & Level 1995 & 58.4 & 82.7 & 106.7 \\
\hline & $\%$ change, $1986-1995$ & -6.2 & 2.5 & -0.4 \\
\hline & Percentage point change & -3.8 & 2.0 & -0.5 \\
\hline \multirow[t]{3}{*}{ France } & Level 1990 & 74.8 & 92.0 & 116.0 \\
\hline & $\%$ change, 1979-1990 & -0.3 & 0.5 & -0.6 \\
\hline & Percentage point change & -0.2 & 0.5 & -0.7 \\
\hline \multirow[t]{3}{*}{ Germany } & Level 1994 & 55.9 & 89.3 & 122.3 \\
\hline & $\%$ change, $1984-1994$ & -14.5 & -1.3 & 3.0 \\
\hline & Percentage point change & -9.5 & -1.2 & 3.6 \\
\hline \multirow[t]{3}{*}{ Italy } & Level 1993 & 51.0 & 77.4 & 131.2 \\
\hline & $\%$ change, $1984-1993$ & -2.5 & -6.6 & 5.1 \\
\hline & Percentage point change & -1.3 & -5.5 & 6.3 \\
\hline \multirow[t]{3}{*}{ Japan } & Level 1994 & 62.7 & 88.7 & 110.0 \\
\hline & \% change, 1984-1994 & 9.2 & -5.3 & 3.5 \\
\hline & Percentage point change & 5.3 & -5.0 & 3.8 \\
\hline \multirow[t]{3}{*}{ Netherlands } & Level 1994 & 62.0 & 89.7 & 119.3 \\
\hline & $\%$ change, $1977-1994$ & -15.0 & 0.1 & 1.5 \\
\hline & Percentage point change & -10.9 & 0.1 & 1.7 \\
\hline \multirow[t]{3}{*}{ Norway } & Level 1995 & 49.4 & 85.7 & 115.4 \\
\hline & $\%$ change, $1986-1995$ & 5.2 & -0.2 & -0.1 \\
\hline & Percentage point change & 2.4 & -0.2 & -0.1 \\
\hline \multirow[t]{3}{*}{ Sweden } & Level 1995 & 58.2 & 80.8 & 115.1 \\
\hline & $\%$ change, $1975-1995$ & 20.6 & -7.2 & 2.7 \\
\hline & Percentage point change & 9.9 & -6.3 & 3.0 \\
\hline \multirow[t]{3}{*}{ United States } & Level 1995 & 39.6 & 82.2 & 116.7 \\
\hline & $\%$ change, 1974-1995 & 3.3 & -5.7 & 2.7 \\
\hline & Percentage point change & 1.3 & -5.0 & 3.1 \\
\hline
\end{tabular}

Note: Relative disposable income is the equivalent disposable income of the household group as a per cent of the mean income of total population. Two workers refers to two or more workers. See Annex 1, Section 7.2 for method.

Source: OECD. 
Table 4.2. Relative disposable income, by age of household head

Equivalence scale elasticity $=0.5$

\begin{tabular}{|c|c|c|c|c|c|}
\hline & & $\begin{array}{c}\text { Young } \\
\text { Household }\end{array}$ & $\begin{array}{l}\text { Prime Age } \\
\text { Household }\end{array}$ & $\begin{array}{c}\text { Older Age } \\
\text { Household }\end{array}$ & $\begin{array}{c}\text { Retired } \\
\text { Household }\end{array}$ \\
\hline \multirow[t]{3}{*}{ Australia } & Level 1993/94 & 101.1 & 101.4 & 110.9 & 68.2 \\
\hline & $\%$ change, $1975 / 76-1993 / 94$ & -4.2 & 1.4 & 2.9 & -7.7 \\
\hline & Percentage point change & -4.4 & 1.4 & 3.1 & -5.7 \\
\hline \multirow[t]{3}{*}{ Belgium } & Level 1995 & .. & .. & .. & .. \\
\hline & $\%$ change, 1983-1995 & .. & .. & .. & .. \\
\hline & Percentage point change & .. & .. & .. &.. \\
\hline \multirow[t]{3}{*}{ Denmark } & Level 1994 & 89.6 & 105.9 & 117.3 & 73.4 \\
\hline & $\%$ change, $1983-1994$ & -10.8 & -1.4 & 10.0 & 6.8 \\
\hline & Percentage point change & -10.9 & -1.5 & 10.7 & 4.7 \\
\hline \multirow[t]{3}{*}{ Finland } & Level 1995 & 80.3 & 106.8 & 114.5 & 78.1 \\
\hline & $\%$ change, 1986-1995 & -8.7 & 0.3 & 6.0 & 1.4 \\
\hline & Percentage point change & -7.6 & 0.3 & 6.4 & 1.1 \\
\hline \multirow[t]{3}{*}{ France } & Level 1990 & 78.7 & 101.7 & 110.1 & 95.0 \\
\hline & $\%$ change, $1979-1990$ & -10.2 & 0.8 & 2.1 & 0.8 \\
\hline & Percentage point change & -8.9 & 0.8 & 2.3 & 0.8 \\
\hline \multirow[t]{3}{*}{ Germany } & Level 1994 & 78.5 & 100.9 & 113.0 & 89.3 \\
\hline & \% change, 1984-1994 & -2.4 & -1.5 & 0.5 & 5.1 \\
\hline & Percentage point change & -1.9 & -1.5 & 0.6 & 4.3 \\
\hline \multirow[t]{3}{*}{ Italy } & Level 1993 & 92.1 & 98.1 & 109.9 & 84.7 \\
\hline & \% change, 1984-1993 & -5.0 & 1.6 & -2.4 & 3.5 \\
\hline & Percentage point change & -4.8 & 1.5 & -2.7 & 2.9 \\
\hline \multirow[t]{3}{*}{ Japan } & Level 1994 & 75.9 & 94.2 & 120.7 & 93.1 \\
\hline & $\%$ change, 1984-1994 & -7.4 & -0.9 & 3.1 & -0.9 \\
\hline & Percentage point change & -6.0 & -0.9 & 3.6 & -0.8 \\
\hline \multirow[t]{3}{*}{ Netherlands } & Level 1994 & 85.2 & 100.8 & 114.0 & 87.5 \\
\hline & \% change, 1977-1994 & -6.4 & 5.2 & -1.9 & -9.2 \\
\hline & Percentage point change & -5.9 & 5.0 & -2.2 & -8.9 \\
\hline \multirow[t]{3}{*}{ Norway } & Level 1995 & 78.0 & 107.3 & 117.3 & 73.7 \\
\hline & \% change, 1986-1995 & -12.8 & 0.5 & 4.1 & 5.7 \\
\hline & Percentage point change & -11.5 & 0.6 & 4.6 & 4.0 \\
\hline \multirow[t]{3}{*}{ Sweden } & Level 1995 & 73.3 & 104.2 & 125.8 & 89.3 \\
\hline & $\%$ change, $1975-1995$ & -17.7 & -4.8 & 10.7 & 22.7 \\
\hline & Percentage point change & -15.8 & -5.3 & 12.2 & 16.5 \\
\hline \multirow[t]{3}{*}{ United States } & Level 1995 & 75.0 & 101.5 & 120.0 & 91.9 \\
\hline & \% change, 1974-1995 & -11.2 & 0.9 & 1.5 & 7.5 \\
\hline & Percentage point change & -9.5 & 0.9 & 1.8 & 6.4 \\
\hline
\end{tabular}

Note: $\quad$ See note to Table 4.1. Young, prime age, older age and retired refer, respectively, to households with heads below 30 , between 30 and below 50 , between 50 and 65 and above 65 years old. See Annex 1, Section 7.2 for method.

Source: OECD. 
Table 4.3. Relative disposable income, by family type

Equivalence scale elasticity $=0.5$

\begin{tabular}{|c|c|c|c|c|c|}
\hline & & $\begin{array}{l}\text { Single adult, } \\
\text { with children }\end{array}$ & $\begin{array}{l}\text { Single adult, no } \\
\text { children }\end{array}$ & $\begin{array}{l}\text { Two adults, with } \\
\text { children }\end{array}$ & $\begin{array}{c}\text { Two adults, no } \\
\text { children }\end{array}$ \\
\hline \multirow[t]{3}{*}{ Australia } & Level 1993/94 & 58.5 & 78.6 & 95.7 & 119.8 \\
\hline & $\%$ change, $1975 / 76-1993 / 94$ & -12.0 & -0.7 & 0.4 & -0.1 \\
\hline & Percentage point change & -8.0 & -0.6 & 0.4 & -0.1 \\
\hline \multirow[t]{3}{*}{ Belgium } & Level 1995 & .73 .7 & 74.2 & 115.3 & 107.8 \\
\hline & $\%$ change, 1983-1995 &.. &.. &.. & .. \\
\hline & Percentage point change & .. & .. & .. & .. \\
\hline \multirow[t]{3}{*}{ Denmark } & Level 1994 & 61.9 & 71.1 & 104.4 & 110.9 \\
\hline & $\%$ change, $1983-1994$ & -4.2 & 0.4 & -2.1 & 3.3 \\
\hline & Percentage point change & -2.7 & 0.3 & -2.2 & 3.5 \\
\hline \multirow[t]{3}{*}{ Finland } & Level 1995 & 77.9 & 71.5 & 103.1 & 108.6 \\
\hline & $\%$ change, 1986-1995 & 1.5 & -0.7 & 0.7 & -1.0 \\
\hline & Percentage point change & 1.2 & -0.5 & 0.7 & -1.0 \\
\hline \multirow[t]{3}{*}{ France } & Level 1990 & 70.3 & 84.4 & 101.2 & 108.0 \\
\hline & $\%$ change, $1979-1990$ & -10.1 & -1.5 & 1.5 & -1.9 \\
\hline & Percentage point change & -7.9 & -1.3 & 1.5 & -2.1 \\
\hline \multirow[t]{3}{*}{ Germany } & Level 1994 & 58.9 & 85.0 & 97.4 & 110.3 \\
\hline & $\%$ change, $1984-1994$ & 4.7 & 3.2 & -0.9 & 0.0 \\
\hline & Percentage point change & 2.7 & 2.7 & -0.9 & 0.0 \\
\hline \multirow[t]{3}{*}{ Italy } & Level 1993 & 54.1 & 71.1 & 93.6 & 112.7 \\
\hline & $\%$ change, 1984-1993 & -7.9 & -5.6 & 0.3 & 0.1 \\
\hline & Percentage point change & -4.6 & -4.3 & 0.3 & 0.1 \\
\hline \multirow[t]{3}{*}{ Japan } & Level 1994 & 57.4 & 82.4 & 94.2 & 121.5 \\
\hline & $\%$ change, 1984-1994 & -2.1 & -5.7 & -0.6 & 2.2 \\
\hline & Percentage point change & -1.2 & -5.0 & -0.5 & 2.6 \\
\hline \multirow[t]{3}{*}{ Netherlands } & Level 1994 & 58.6 & 80.0 & 95.0 & 118.1 \\
\hline & $\%$ change, 1977-1994 & -5.7 & -11.5 & 0.8 & 1.1 \\
\hline & Percentage point change & -3.5 & -10.4 & 0.8 & 1.3 \\
\hline \multirow[t]{3}{*}{ Norway } & Level 1995 & 69.9 & 69.3 & 103.8 & 111.5 \\
\hline & $\%$ change, $1986-1995$ & 1.7 & -3.8 & 0.0 & 0.9 \\
\hline & Percentage point change & 1.1 & -2.7 & 0.0 & 1.0 \\
\hline \multirow[t]{3}{*}{ Sweden } & Level 1995 & 73.9 & 74.5 & 103.7 & 121.7 \\
\hline & $\%$ change, $1975-1995$ & -13.5 & -1.7 & -2.5 & 7.0 \\
\hline & Percentage point change & -11.6 & -1.3 & -2.7 & 8.0 \\
\hline \multirow[t]{3}{*}{ United States } & Level 1995 & 49.9 & 88.4 & 94.9 & 122.4 \\
\hline & $\%$ change, $1974-1995$ & 12.6 & 8.5 & -0.9 & -0.7 \\
\hline & Percentage point change & 5.6 & 7.0 & -0.9 & -0.9 \\
\hline
\end{tabular}

Note: See note to Table 4.1. Two-adult households refers to two-or-more-adult households. See Annex 1, Section 7.2 for method.

Source: OECD. 
ECO/WKP(98)2

Table 4.4. Contribution of earnings and employment to changes in earnings: young and older-worker households

Equivalence scale elasticity $=0.5$

Households with a young and older working-age head

\begin{tabular}{|c|c|c|c|}
\hline & \multirow{2}{*}{$\begin{array}{c}\text { Change in earned income per capita } \\
\text { for each group relative to the } \\
\text { population average } \\
\text { (1) }\end{array}$} & \multicolumn{2}{|c|}{ Contribution to total change due to: } \\
\hline & & $\begin{array}{c}\text { Earnings effect } \\
\text { (2) }\end{array}$ & $\begin{array}{c}\text { Employment effect } \\
\text { (3) }\end{array}$ \\
\hline & & Young adult heads & \\
\hline Australia, 1975-94 & -1.3 & 4.2 & -5.6 \\
\hline \multicolumn{4}{|l|}{ Belgium, 1983-95 } \\
\hline Denmark, 1983-95 & -12.0 & -7.0 & -5.0 \\
\hline Finland, 1986-95 & -14.6 & -7.0 & -7.6 \\
\hline France, 1979-90 & -12.9 & -9.7 & -3.2 \\
\hline Germany, 1984-94 & 3.9 & 6.9 & -2.9 \\
\hline Italy, $1984-93^{4}$ & -18.1 & -14.7 & -3.4 \\
\hline Japan, 1984-94 & -15.6 & -15.7 & 0.1 \\
\hline Netherlands, 1977-94 & -9.6 & -1.5 & -8.1 \\
\hline Norway, 1986-95 & -17.1 & -2.9 & -14.3 \\
\hline Sweden, 1975-95 & -20.9 & -9.4 & -11.4 \\
\hline \multirow[t]{2}{*}{ United States, 1974-95 } & -14.6 & -15.7 & 1.1 \\
\hline & & Older working-age hea & \\
\hline Australia, 1975-94 & -9.3 & 0.9 & -10.2 \\
\hline \multicolumn{4}{|l|}{ Belgium, 1983-95 } \\
\hline Denmark, 1983-95 & 12.1 & 7.5 & 4.5 \\
\hline Finland, 1986-95 & 16.0 & 20.6 & -4.6 \\
\hline France, 1979-90 & 0.0 & 4.4 & -4.4 \\
\hline Germany, 1984-94 & 7.3 & 7.8 & -0.5 \\
\hline Italy, 1984-93 & -3.3 & 6.9 & -10.2 \\
\hline Japan, 198-94 & 14.6 & 15.3 & -0.7 \\
\hline Netherlands, 1977-94 & -10.2 & 9.0 & -19.2 \\
\hline Norway, 1986-95 & 5.8 & 11.7 & -5.9 \\
\hline Sweden, 1975-95 & 20.8 & 21.3 & -0.5 \\
\hline United States, 1974-95 & 0.9 & 3.7 & -2.8 \\
\hline
\end{tabular}

. Change in earned income per capita of each group is relative to earned income per capita for the whole population.

2. Change in relative earned income arising from a change in the relative position of earnings of each work-attachment group ("Earnings effect").

3. Change in relative earned income due to changes in the share of individuals belonging to the different work-attachment groups ("Employment effect").

4. Data for Italy, for this group, should be treated with caution.

Note: $\quad$ See Annex 1, Section 7.2 for method.

Source: OECD. 


\section{ECO/WKP(98)2}

Table 4.5. Contribution of earnings and employment to changes in earnings: households with children

Equivalence scale elasticity $=0.5$

Households with children

\begin{tabular}{|c|c|c|c|}
\hline & \multirow{2}{*}{$\begin{array}{l}\text { Change in earned income per capita } \\
\text { for each group relative to the } \\
\text { population average } \\
\text { (1) }\end{array}$} & \multicolumn{2}{|c|}{ Contribution to total change due to: } \\
\hline & & $\begin{array}{l}\text { Earnings effect } \\
\text { (2) }\end{array}$ & $\begin{array}{c}\text { Employment effect } \\
\text { (3) }\end{array}$ \\
\hline & & Single-parent household & \\
\hline \multirow{2}{*}{\multicolumn{4}{|c|}{ Belgium, 1983-95 }} \\
\hline & & & \\
\hline Denmark, 1983-95 & -10.2 & -5.9 & -4.4 \\
\hline Finland, 1986-95 & -11.3 & 1.3 & -12.6 \\
\hline France, $1979-90$ & -6.7 & -4.8 & -1.9 \\
\hline Germany, 1984-94 & -1.9 & -2.2 & 0.3 \\
\hline Italy, 1984-93 & -7.9 & 13.6 & -21.4 \\
\hline Japan, 1984-94 & 3.1 & 0.8 & 2.3 \\
\hline Netherlands, $1977-94$ & 5.0 & 0.0 & 5.0 \\
\hline Norway, 1986-95 & 3.5 & 6.2 & -2.7 \\
\hline Sweden, 1975-95 & -4.8 & $\begin{array}{l}0.2 \\
-2.0\end{array}$ & -2.8 \\
\hline \multirow{2}{*}{ United States, 1974-95 } & 9.2 & 4.3 & 4.9 \\
\hline & & Two-parent household & \\
\hline Australia, 1975-94 & 3.8 & 6.2 & -2.4 \\
\hline Belgium, 1983-95 & & & \\
\hline Denmark, 1983-95 & 3.4 & 0.0 & 3.4 \\
\hline Finland, 1986-95 & 8.5 & 7.5 & 1.0 \\
\hline France, $1979-90$ & 5.8 & -2.2 & 8.0 \\
\hline Germany, 1984-94 & 0.5 & 1.2 & -0.7 \\
\hline $\begin{array}{l}\text { Italy, 1984-93 } \\
\text { Int }\end{array}$ & 9.3 & 10.4 & $\begin{array}{l}-0.1 \\
-1.1\end{array}$ \\
\hline Japan, 1984-94 & 1.1 & 1.0 & 0.1 \\
\hline Netherlands, 1977-94 & 6.1 & 2.9 & 3.2 \\
\hline Norway, 1986-95 & 9.9 & 7.4 & 2.5 \\
\hline Sweden, 1975-95 & 8.6 & 8.1 & 0.5 \\
\hline United States, 1974-95 & 1.7 & -1.7 & 3.4 \\
\hline
\end{tabular}

1. Change in earned income per capita of each group is relative to earned income per capita for the whole population.

2. Change in relative earned income arising from a change in the relative position of earnings of each work-attachment group ("Earnings effect").

3. Change in relative earned income due to changes in the share of individuals belonging to the different work-attachment groups ("Employment effect").

Note: $\quad$ See Annex 1, Section 7.2 for method.

Source: OECD. 
Table 4.6. Relative disposable income of non-working households ${ }^{1}$

Equivalence scale elasticity $=0.5$

Per cent, and changes in percentage points

\begin{tabular}{|c|c|c|c|c|c|}
\hline & & \multicolumn{4}{|c|}{ By age of household head } \\
\hline & & Young head & $\begin{array}{c}\text { Prime-age } \\
\text { head }\end{array}$ & $\begin{array}{l}\text { Older working- } \\
\text { age head }\end{array}$ & $\begin{array}{l}\text { Working- } \\
\text { age head }\end{array}$ \\
\hline \multirow[t]{2}{*}{ Australia } & Level, 1993/94 & 44.5 & 46.6 & 53.3 & 46.2 \\
\hline & Changes, 1975/76-1993/94 & 6.3 & 8.1 & 4.7 & 4.3 \\
\hline \multirow[t]{2}{*}{ Belgium } & Level, 1995 & .. & .. & .. & .. \\
\hline & Changes, 1983-1995 & .. & .. & .. & .. \\
\hline \multirow[t]{2}{*}{ Denmark } & Level, 1994 & 51.9 & 67.6 & 80.4 & 67.0 \\
\hline & Changes, 1983-1994 & 6.2 & -2.0 & 6.5 & 1.9 \\
\hline \multirow[t]{2}{*}{ Finland } & Level, 1995 & 45.4 & 59.9 & 70.1 & 59.3 \\
\hline & Changes, 1986-1995 & 5.4 & 1.0 & 1.2 & -2.9 \\
\hline \multirow[t]{2}{*}{ France } & Level, 1990 & 39.6 & 50.5 & 83.5 & 73.8 \\
\hline & Changes, $1979-1990$ & -4.7 & -11.4 & 3.5 & -1.2 \\
\hline \multirow[t]{2}{*}{ Germany } & Level, 1994 & 39.3 & 42.6 & 74.6 & 56.7 \\
\hline & Changes, 1984-1994 & -3.3 & -8.9 & -7.1 & -8.6 \\
\hline \multirow[t]{2}{*}{ Italy } & Level, 1993 & 33.8 & 30.9 & 60.2 & 51.5 \\
\hline & Changes, 1984-1993 & .. & 7.0 & 1.9 & -0.7 \\
\hline \multirow[t]{2}{*}{ Japan } & Level, 1994 & 38.8 & 56.2 & 64.8 & 62.6 \\
\hline & Changes, 1984-1994 & -9.4 & 11.6 & 4.0 & 5.2 \\
\hline \multirow[t]{2}{*}{ Netherlands } & Level, 1994 & 42.0 & 53.8 & 81.0 & 62.1 \\
\hline & Changes, 1977-1994 & -11.6 & -11.8 & -3.3 & -10.8 \\
\hline \multirow[t]{2}{*}{ Norway } & Level, 1995 & 35.9 & 59.2 & 68.6 & 50.7 \\
\hline & Changes, 1986-1995 & 2.4 & 6.4 & 6.7 & 3.6 \\
\hline \multirow[t]{2}{*}{ Sweden } & Level, 1995 & 38.1 & 61.8 & 83.7 & 59.6 \\
\hline & Changes, 1975-1995 & 13.9 & 8.8 & 16.1 & 11.3 \\
\hline \multirow[t]{2}{*}{ United States } & Level, 1995 & 21.8 & 29.9 & 59.0 & 39.0 \\
\hline & Changes, 1974-1995 & -3.4 & -2.9 & 5.6 & 0.7 \\
\hline
\end{tabular}

1. See note to Table 4.1.

Source: OECD. 


\section{Table 4.7. Relative disposable income of children, the elderly and single earners with children ${ }^{1}$}

Equivalence scale elasticity $=0.5$

Per cent, and changes in percentage points

\begin{tabular}{|c|c|c|c|c|c|c|c|}
\hline & \multicolumn{3}{|c|}{ By age of individuals } & \multirow{2}{*}{$\begin{array}{c}\text { By age of } \\
\text { household head } \\
\text { Over } 65 \\
\text { not working } \\
\end{array}$} & \multicolumn{2}{|c|}{$\begin{array}{c}\text { Single-earner households } \\
\text { with children }\end{array}$} \\
\hline & & $\begin{array}{c}\text { Age } 0- \\
17\end{array}$ & Age 65-7 & Age $75+$ & & $\begin{array}{l}\text { Single } \\
\text { parent }\end{array}$ & $\begin{array}{c}\text { Two } \\
\text { parents }\end{array}$ \\
\hline \multirow{2}{*}{ Australia } & Level, 1993/94 & 84.8 & \multicolumn{2}{|c|}{66.1} & 59.2 & 72.9 & 74.8 \\
\hline & Changes, 1975/76-1993/94 & -4.7 & \multicolumn{2}{|c|}{-5.8} & 6.8 & -10.1 & 0.5 \\
\hline \multirow[t]{2}{*}{ Belgium } & Level, 1995 & 104.9 & 82.6 & 70.7 & .. & 74.4 & 97.5 \\
\hline & Changes, 1983-1995 &.. &.. &.. & .. &.. &.. \\
\hline \multirow{2}{*}{ Denmark } & Level, 1994 & 96.7 & 78.3 & 64.3 & 69.6 & 66.6 & 90.5 \\
\hline & Changes, 1983-1994 & -2.9 & 4.4 & 4.7 & 5.0 & -2.7 & 4.2 \\
\hline \multirow[t]{2}{*}{ Finland } & Level, 1995 & 100.4 & 81.2 & 74.3 & 75.2 & 84.3 & 81.3 \\
\hline & Changes, 1986-1995 & 2.3 & 1.0 & 0.4 & 1.6 & 6.2 & 2.9 \\
\hline \multirow[t]{2}{*}{ France } & Level, 1990 & 92.1 & 99.4 & 89.0 & 92.0 & 76.7 & 89.6 \\
\hline & Changes, $1979-90$ & -0.4 & 3.9 & 2.0 & 5.8 & -4.6 & -0.5 \\
\hline \multirow[t]{2}{*}{ Germany } & Level, 1994 & 91.5 & 93.3 & 78.0 & 83.2 & 74.8 & 88.9 \\
\hline & Changes, 1984-1994 & -1.9 & 8.3 & -2.6 & 4.5 & 5.0 & 1.0 \\
\hline \multirow[t]{2}{*}{ Italy } & Level, 1993 & 89.3 & 85.7 & 82.1 & 71.4 & 68.4 & 70.5 \\
\hline & Changes, 1984-1993 & -0.9 & 3.3 & 4.1 & 5.5 & 1.8 & -6.4 \\
\hline \multirow[t]{2}{*}{ Japan } & Level, 1994 & 88.2 & 92.5 & 98.0 & 82.1 & 53.2 & 83.7 \\
\hline & Changes, 1984-1994 & -3.7 & -0.2 & -0.7 & 5.6 & -10.9 & -6.1 \\
\hline \multirow[t]{2}{*}{ Netherlands } & Level, 1994 & 88.9 & 89.8 & 78.8 & 82.7 & 74.7 & 84.2 \\
\hline & Changes, 1977-1994 & -1.1 & -1.8 & -13.5 & -2.7 & -3.7 & -1.4 \\
\hline \multirow[t]{2}{*}{ Norway } & Level, 1995 & 97.4 & 84.2 & 61.1 & 65.6 & 81.9 & 85.2 \\
\hline & Changes, 1986-1995 & 0.9 & 6.6 & 1.0 & 3.4 & -0.5 & 0.4 \\
\hline \multirow[t]{2}{*}{ Sweden } & Level, 1995 & 97.9 & 95.4 & 77.5 & 86.1 & 78.5 & 82.1 \\
\hline & Changes, 1975-1995 & -3.9 & 15.6 & 16.8 & 15.9 & -9.5 & -4.9 \\
\hline \multirow[t]{2}{*}{ United States } & Level, 1995 & 83.7 & 98.4 & 81.7 & 75.6 & 59.5 & 73.4 \\
\hline & Changes, 1974-1995 & -2.1 & 8.5 & 3.8 & 9.5 & 5.7 & -12.2 \\
\hline
\end{tabular}

1. See note to Table 4.1.

Source: OECD. 
Table 4.8. Population structure by work attachment and household type

$\mathrm{ECO} / \mathrm{WKP}(98) 2$

Per cent, and changes in percentage points

\begin{tabular}{|c|c|c|c|c|c|c|c|c|c|c|c|c|c|c|}
\hline & \multirow{2}{*}{\multicolumn{3}{|c|}{$\begin{array}{c}\text { Working-age population }^{1} \\
\text { By work attachment }\end{array}$}} & \multicolumn{11}{|c|}{ Total population } \\
\hline & & & & \multicolumn{3}{|c|}{ By work attachment } & \multicolumn{4}{|c|}{ By age of head } & \multicolumn{4}{|c|}{ By family type } \\
\hline & $\begin{array}{l}\text { Two } \\
\text { workers }\end{array}$ & $\begin{array}{l}\text { One } \\
\text { worker }\end{array}$ & $\begin{array}{l}\text { No } \\
\text { worker }\end{array}$ & $\begin{array}{l}\text { Two } \\
\text { workers }\end{array}$ & $\begin{array}{l}\text { One } \\
\text { worker }\end{array}$ & $\begin{array}{l}\text { No } \\
\text { worker }\end{array}$ & $\begin{array}{l}\text { Young } \\
\text { head }\end{array}$ & $\begin{array}{l}\text { Prime- } \\
\text { age } \\
\text { head }\end{array}$ & $\begin{array}{c}\text { Older } \\
\text { working- } \\
\text { age head }\end{array}$ & $\begin{array}{l}\text { Retirement } \\
\text { age head }\end{array}$ & $\begin{array}{l}\text { Single } \\
\text { adult with } \\
\text { children }\end{array}$ & $\begin{array}{l}\text { Single } \\
\text { adult, no } \\
\text { children }\end{array}$ & $\begin{array}{l}\text { Two adults } \\
\text { with } \\
\text { children }\end{array}$ & $\begin{array}{l}\text { Two } \\
\text { adults, no } \\
\text { children } \\
\end{array}$ \\
\hline $\begin{array}{l}\text { Australia, 1993/94 } \\
\quad \text { Changes, 1975-1993 }\end{array}$ & $\begin{array}{r}55.6 \\
2.0\end{array}$ & $\begin{array}{r}30.8 \\
-9.6\end{array}$ & $\begin{array}{r}13.6 \\
7.6\end{array}$ & $\begin{array}{l}49.3 \\
-0.3\end{array}$ & $\begin{array}{r}28.7 \\
-10.3\end{array}$ & $\begin{array}{l}22.0 \\
10.6\end{array}$ & $\begin{array}{l}13.3 \\
-5.3\end{array}$ & $\begin{array}{r}53.7 \\
0.9\end{array}$ & $\begin{array}{r}19.9 \\
0.8\end{array}$ & $\begin{array}{r}13.1 \\
3.6\end{array}$ & $\begin{array}{l}5.3 \\
2.6\end{array}$ & $\begin{array}{l}8.3 \\
3.4\end{array}$ & $\begin{array}{r}46.9 \\
-19.0\end{array}$ & $\begin{array}{l}39.5 \\
13.2\end{array}$ \\
\hline $\begin{array}{l}\text { Belgium, } 1995 \\
\quad \text { Changes, 1983-1995 }\end{array}$ & $\begin{array}{l}. . \\
. .\end{array}$ & $\begin{array}{l}. . \\
. .\end{array}$ & $\begin{array}{l}. . \\
. .\end{array}$ & $\begin{array}{l}. . \\
. .\end{array}$ & $\begin{array}{l}. . \\
. .\end{array}$ & $\begin{array}{l}. . \\
. .\end{array}$ & $\begin{array}{l}. . \\
. .\end{array}$ & $\begin{array}{l}. . \\
. .\end{array}$ & $\begin{array}{l}. . \\
. .\end{array}$ & $\begin{array}{l}. . \\
. .\end{array}$ & $\begin{array}{l}4.5 \\
. .\end{array}$ & $\begin{array}{c}27.8 \\
. .\end{array}$ & $\begin{array}{c}40.7 \\
. .\end{array}$ & $\begin{array}{c}27.0 \\
. .\end{array}$ \\
\hline $\begin{array}{l}\text { Denmark, } 1994 \\
\text { Changes, 1983-1994 }\end{array}$ & $\begin{array}{r}62.4 \\
0.2\end{array}$ & $\begin{array}{r}27.9 \\
-0.9\end{array}$ & $\begin{array}{l}9.7 \\
0.7\end{array}$ & $\begin{array}{r}52.4 \\
-0.3\end{array}$ & $\begin{array}{r}24.6 \\
-1.1\end{array}$ & $\begin{array}{r}23.0 \\
1.4\end{array}$ & $\begin{array}{l}16.7 \\
-1.3\end{array}$ & $\begin{array}{r}48.1 \\
0.0\end{array}$ & $\begin{array}{r}19.0 \\
0.6\end{array}$ & $\begin{array}{r}16.2 \\
0.6\end{array}$ & $\begin{array}{l}4.9 \\
0.6\end{array}$ & $\begin{array}{r}17.2 \\
3.0\end{array}$ & $\begin{array}{l}40.7 \\
-7.7\end{array}$ & $\begin{array}{r}37.3 \\
4.1\end{array}$ \\
\hline $\begin{array}{l}\text { Finland, } 1995 \\
\text { Changes, 1986-1995 }\end{array}$ & $\begin{array}{r}72.3 \\
-2.5\end{array}$ & $\begin{array}{r}20.8 \\
-1.6\end{array}$ & $\begin{array}{l}6.9 \\
4.1\end{array}$ & $\begin{array}{l}62.1 \\
-4.3\end{array}$ & $\begin{array}{l}19.1 \\
-1.8\end{array}$ & $\begin{array}{r}18.7 \\
5.9\end{array}$ & $\begin{array}{l}13.2 \\
-4.8\end{array}$ & $\begin{array}{r}53.8 \\
0.5\end{array}$ & $\begin{array}{r}18.2 \\
1.4\end{array}$ & $\begin{array}{r}14.7 \\
2.7\end{array}$ & $\begin{array}{l}5.5 \\
2.0\end{array}$ & $\begin{array}{r}16.7 \\
3.5\end{array}$ & $\begin{array}{r}45.2 \\
-4.9\end{array}$ & $\begin{array}{l}32.7 \\
-0.6\end{array}$ \\
\hline $\begin{array}{l}\text { France, } 1990 \\
\quad \text { Changes, 1979-1990 }\end{array}$ & $\begin{array}{r}44.2 \\
7.4\end{array}$ & $\begin{array}{r}46.8 \\
-10.2\end{array}$ & $\begin{array}{l}9.0 \\
2.8\end{array}$ & $\begin{array}{r}37.8 \\
6.2\end{array}$ & $\begin{array}{r}41.1 \\
-9.2\end{array}$ & $\begin{array}{r}21.1 \\
3.0\end{array}$ & $\begin{array}{l}10.5 \\
-1.1\end{array}$ & $\begin{array}{r}52.7 \\
2.5\end{array}$ & $\begin{array}{r}22.1 \\
-1.3\end{array}$ & $\begin{array}{l}14.7 \\
-0.1\end{array}$ & $\begin{array}{l}6.3 \\
2.1\end{array}$ & $\begin{array}{r}10.5 \\
1.7\end{array}$ & $\begin{array}{r}59.7 \\
-4.0\end{array}$ & $\begin{array}{r}23.4 \\
0.2\end{array}$ \\
\hline $\begin{array}{l}\text { Germany, } 1994 \\
\quad \text { Changes, 1984-1994 }\end{array}$ & $\begin{array}{r}39.6 \\
-3.0\end{array}$ & $\begin{array}{r}48.9 \\
1.4\end{array}$ & $\begin{array}{r}11.5 \\
1.5\end{array}$ & $\begin{array}{l}32.7 \\
-3.6\end{array}$ & $\begin{array}{r}41.2 \\
-0.2\end{array}$ & $\begin{array}{r}26.1 \\
3.8\end{array}$ & $\begin{array}{l}9.8 \\
0.4\end{array}$ & $\begin{array}{l}45.7 \\
-1.6\end{array}$ & $\begin{array}{r}25.1 \\
-1.2\end{array}$ & $\begin{array}{r}19.4 \\
2.4\end{array}$ & $\begin{array}{l}3.0 \\
1.4\end{array}$ & $\begin{array}{r}16.7 \\
2.9\end{array}$ & $\begin{array}{r}41.9 \\
-3.7\end{array}$ & $\begin{array}{r}38.5 \\
-0.4\end{array}$ \\
\hline $\begin{array}{l}\text { Italy, } 1993 \\
\quad \text { Changes, 1984-1993 }\end{array}$ & $\begin{array}{r}44.8 \\
0.2\end{array}$ & $\begin{array}{l}45.2 \\
-4.8\end{array}$ & $\begin{array}{r}10.0 \\
4.6\end{array}$ & $\begin{array}{r}38.4 \\
-1.6\end{array}$ & $\begin{array}{l}40.8 \\
-5.6\end{array}$ & $\begin{array}{r}20.7 \\
7.1\end{array}$ & $\begin{array}{l}4.5 \\
0.2\end{array}$ & $\begin{array}{r}46.5 \\
-1.1\end{array}$ & $\begin{array}{l}31.3 \\
-2.8\end{array}$ & $\begin{array}{r}17.6 \\
3.6\end{array}$ & $\begin{array}{l}1.2 \\
0.6\end{array}$ & $\begin{array}{l}5.3 \\
1.1\end{array}$ & $\begin{array}{r}49.6 \\
-6.1\end{array}$ & $\begin{array}{r}43.9 \\
4.4\end{array}$ \\
\hline $\begin{array}{l}\text { Japan, } 1994 \\
\quad \text { Changes, 1984-1994 }\end{array}$ & $\begin{array}{r}56.5 \\
1.4\end{array}$ & $\begin{array}{r}41.4 \\
-1.8\end{array}$ & $\begin{array}{l}2.1 \\
0.4\end{array}$ & $\begin{array}{l}51.7 \\
-1.8\end{array}$ & $\begin{array}{l}38.9 \\
-2.9\end{array}$ & $\begin{array}{l}9.4 \\
4.6\end{array}$ & $\begin{array}{r}5.0 \\
-1.2\end{array}$ & $\begin{array}{r}52.5 \\
-7.2\end{array}$ & $\begin{array}{r}30.3 \\
3.7\end{array}$ & $\begin{array}{r}12.2 \\
4.7\end{array}$ & $\begin{array}{r}0.5 \\
-0.2\end{array}$ & $\begin{array}{l}6.6 \\
1.3\end{array}$ & $\begin{array}{r}57.0 \\
-12.5\end{array}$ & $\begin{array}{l}35.8 \\
11.4\end{array}$ \\
\hline $\begin{array}{l}\text { Netherlands, } 1994 \\
\quad \text { Changes, 1977-1994 }\end{array}$ & $\begin{array}{r}48.1 \\
7.0\end{array}$ & $\begin{array}{r}37.2 \\
-14.8\end{array}$ & $\begin{array}{r}14.7 \\
7.8\end{array}$ & $\begin{array}{r}41.2 \\
4.7\end{array}$ & $\begin{array}{r}33.1 \\
-13.9\end{array}$ & $\begin{array}{r}25.6 \\
9.3\end{array}$ & $\begin{array}{l}11.5 \\
-1.0\end{array}$ & $\begin{array}{r}52.9 \\
3.4\end{array}$ & $\begin{array}{r}20.6 \\
-3.4\end{array}$ & $\begin{array}{r}14.9 \\
1.1\end{array}$ & $\begin{array}{l}3.6 \\
2.1\end{array}$ & $\begin{array}{r}15.1 \\
7.4\end{array}$ & $\begin{array}{r}42.8 \\
-18.4\end{array}$ & $\begin{array}{r}38.3 \\
8.8\end{array}$ \\
\hline $\begin{array}{l}\text { Norway, } 1995 \\
\text { Changes, 1986-1995 }\end{array}$ & $\begin{array}{r}53.9 \\
-2.3\end{array}$ & $\begin{array}{r}34.7 \\
-2.4\end{array}$ & $\begin{array}{r}11.4 \\
4.7\end{array}$ & $\begin{array}{r}46.1 \\
-2.8\end{array}$ & $\begin{array}{r}30.7 \\
-2.7\end{array}$ & $\begin{array}{r}23.1 \\
5.3\end{array}$ & $\begin{array}{r}14.8 \\
-0.4\end{array}$ & $\begin{array}{r}53.1 \\
1.4\end{array}$ & $\begin{array}{r}17.2 \\
-1.6\end{array}$ & $\begin{array}{r}14.8 \\
0.4\end{array}$ & $\begin{array}{l}7.0 \\
2.3\end{array}$ & $\begin{array}{r}18.1 \\
4.4\end{array}$ & $\begin{array}{r}44.3 \\
-4.0\end{array}$ & $\begin{array}{r}30.1 \\
-2.7\end{array}$ \\
\hline $\begin{array}{l}\text { Sweden, } 1995 \\
\text { Changes, 1975-1995 }\end{array}$ & $\begin{array}{l}54.7 \\
-4.6\end{array}$ & $\begin{array}{r}37.3 \\
1.4\end{array}$ & $\begin{array}{l}8.1 \\
3.2\end{array}$ & $\begin{array}{r}45.1 \\
-4.0\end{array}$ & $\begin{array}{r}31.9 \\
0.9\end{array}$ & $\begin{array}{r}23.0 \\
3.1\end{array}$ & $\begin{array}{l}17.8 \\
-2.1\end{array}$ & $\begin{array}{r}46.0 \\
3.9\end{array}$ & $\begin{array}{l}18.6 \\
-2.2\end{array}$ & $\begin{array}{r}17.6 \\
0.4\end{array}$ & $\begin{array}{l}7.7 \\
2.2\end{array}$ & $\begin{array}{r}29.0 \\
5.5\end{array}$ & $\begin{array}{l}36.2 \\
-8.1\end{array}$ & $\begin{array}{r}27.0 \\
0.3\end{array}$ \\
\hline $\begin{array}{l}\text { United States, } 1995 \\
\quad \text { Changes, 1974-1995 }\end{array}$ & $\begin{array}{r}63.6 \\
5.9\end{array}$ & $\begin{array}{r}30.2 \\
-7.0\end{array}$ & $\begin{array}{l}6.2 \\
1.2\end{array}$ & $\begin{array}{r}56.8 \\
4.0\end{array}$ & $\begin{array}{r}29.4 \\
-7.1\end{array}$ & $\begin{array}{r}13.9 \\
3.1\end{array}$ & $\begin{array}{l}13.4 \\
-3.9\end{array}$ & $\begin{array}{r}53.4 \\
6.0\end{array}$ & $\begin{array}{r}18.9 \\
-4.0\end{array}$ & $\begin{array}{r}14.2 \\
1.9\end{array}$ & $\begin{array}{l}6.8 \\
1.4\end{array}$ & $\begin{array}{l}9.4 \\
2.7\end{array}$ & $\begin{array}{r}50.0 \\
-9.0\end{array}$ & $\begin{array}{r}33.7 \\
4.9\end{array}$ \\
\hline
\end{tabular}

1. Persons living in households with head less than 65 .

Source: OECD. 
Table 4.9. Changes in inequality: between-group and within-group effects

Equivalence elasticity $=0.5$

Levels and absolute changes

\begin{tabular}{|c|c|c|c|}
\hline & Total MLD & MLD Between group & MLD Within group \\
\hline Australia, level in 1993/94 & 17.8 & 7.4 & 10.4 \\
\hline changes, 1975/76-1993/94 & 2.1 & 1.3 & 0.8 \\
\hline share of total change & $100.0 \%$ & $63.1 \%$ & $36.9 \%$ \\
\hline Belgium, level in 1995 & 14.0 & .. & .. \\
\hline changes, 1983-1995 & 0.4 & .. & .. \\
\hline share of total change &.. & .. & .. \\
\hline Denmark, level in 1994 & 8.8 & 2.7 & 6.1 \\
\hline changes, 1983-1994 & -1.5 & -0.1 & -1.3 \\
\hline share of total change & $100.0 \%$ & $9.5 \%$ & $90.5 \%$ \\
\hline Finland, level in 1995 & 9.0 & 2.1 & 6.9 \\
\hline changes, 1986-1995 & 1.2 & 0.5 & 0.7 \\
\hline share of total change & $100.0 \%$ & $39.6 \%$ & $60.4 \%$ \\
\hline France, level in 1990 & 29.5 & 4.2 & 25.3 \\
\hline changes, 1979-1990 & -4.7 & 0.1 & -4.7 \\
\hline share of total change & $100.0 \%$ & $-1.5 \%$ & $101.5 \%$ \\
\hline Germany, level in 1994 & 13.5 & 3.3 & 10.2 \\
\hline changes, 1984-1994 & 1.6 & 0.9 & 0.6 \\
\hline share of total change & $100.0 \%$ & $60.3 \%$ & $39.7 \%$ \\
\hline Italy, level in 1993 & 24.0 & 6.8 & 17.2 \\
\hline changes, 1984-1993 & 7.0 & 2.3 & 4.7 \\
\hline share of total change & $100.0 \%$ & $33.5 \%$ & $66.5 \%$ \\
\hline Japan, level in 1994 & 12.6 & 1.5 & 11.1 \\
\hline changes, 1984-1994 & 1.5 & 0.5 & 1.0 \\
\hline share of total change & $100.0 \%$ & $31.3 \%$ & $68.7 \%$ \\
\hline Netherlands, level in 1994 & 11.6 & 3.1 & 8.4 \\
\hline changes, 1977-1994 & 2.7 & 1.11 .6 & 1.0 \\
\hline share of total change & $100.0 \%$ & $61.3 \%$ & $38.7 \%$ \\
\hline Norway, level in 1995 & 13.1 & 4.6 & 8.5 \\
\hline changes, 1986-1995 & 3.1 & 0.7 & 2.4 \\
\hline share of total change & $100.0 \%$ & $24.1 \%$ & $75.9 \%$ \\
\hline Sweden, level in 1995 & 11.0 & 3.3 & 7.7 \\
\hline changes, 1975-1995 & 0.2 & 0.1 & 0.1 \\
\hline share of total change & $100.0 \%$ & $39.0 \%$ & $61.0 \%$ \\
\hline United States, level in 1995 & 21.9 & 4.5 & 17.4 \\
\hline changes, 1974-1995 & 3.7 & 1.0 & 2.7 \\
\hline share of total change & $100.0 \%$ & $28.3 \%$ & $71.7 \%$ \\
\hline
\end{tabular}

Note: $\quad$ See Annex 1, Section 7.3 for the methodology.

Source: OECD. 


\section{Table 4.10. Decomposition of the changes in MLD by work attachment}

Equivalence scale elasticity $=0.5$ Absolute changes

\begin{tabular}{|c|c|c|c|c|c|c|c|c|c|c|c|c|c|}
\hline & \multicolumn{4}{|c|}{ Total change } & \multicolumn{9}{|c|}{ MLD decomposition due to: } \\
\hline & \multirow[b]{2}{*}{ Total } & \multirow[b]{2}{*}{ Within } & \multirow[b]{2}{*}{ Between } & \multirow[b]{2}{*}{ Structural } & \multicolumn{3}{|c|}{ Within-group inequality } & \multicolumn{3}{|c|}{ Between-group inequality } & \multicolumn{3}{|c|}{ Structural effect } \\
\hline & & & & & 2 workers & 1 worker & No worker & 2 workers & 1 worker & No worker & 2 workers & 1 worker & No worker \\
\hline Australia, 1975/76-1993/94 & 2.1 & 0.5 & -2.0 & 3.6 & 0.4 & 0.7 & -0.7 & 1.5 & -1.2 & -2.3 & -3.3 & -7.6 & 14.5 \\
\hline Belgium, 1983-1995 & 0.4 & .. & .. & .. & .. & .. & .. & .. & .. & .. & .. & .. & .. \\
\hline Denmark, 1983-1994 & -1.5 & -1.1 & -0.6 & 0.2 & -0.1 & 0.0 & -0.9 & 0.8 & -0.2 & -1.2 & -0.2 & -0.3 & 0.6 \\
\hline Finland, 1986-1995 & 1.2 & 1.0 & 0.2 & 0.0 & 1.4 & -0.3 & -0.1 & 0.1 & -0.6 & 0.6 & -1.5 & -1.1 & 2.6 \\
\hline France, 1979-1990 & -4.7 & -1.4 & -1.8 & -1.4 & 1.9 & -0.9 & -2.4 & 2.1 & 3.4 & -7.3 & 0.1 & -11.3 & 9.9 \\
\hline Germany, 1984-1994 & 1.6 & 1.0 & 0.4 & 0.2 & -0.1 & 0.7 & 0.4 & -0.7 & 0.6 & 0.5 & -0.2 & -0.8 & 1.2 \\
\hline Italy, 1984-1993 & 7.0 & 5.0 & 1.1 & 0.9 & 1.9 & 2.0 & 1.1 & -2.5 & 4.0 & -0.4 & -0.9 & -4.3 & 6.1 \\
\hline Japan, 1984-1994 & 1.5 & 0.7 & -0.1 & 0.9 & 0.4 & 0.4 & -0.1 & -1.6 & 2.2 & -0.7 & -0.5 & -0.9 & 2.3 \\
\hline Netherlands, 1977-1994 & 2.7 & 1.6 & 1.1 & 0.0 & 0.4 & 0.8 & 0.4 & -0.8 & -0.5 & 2.4 & -0.8 & -2.7 & 3.5 \\
\hline Norway, 1986-1995 & 3.1 & 2.6 & -0.2 & 0.7 & 0.3 & 1.1 & 1.2 & 0.5 & -0.5 & -0.2 & -1.0 & -1.4 & 3.1 \\
\hline Sweden, 1975-1995 & 0.2 & 0.3 & -0.3 & 0.2 & 0.1 & 0.4 & -0.2 & 0.0 & 0.9 & -1.2 & -0.1 & -0.1 & 0.4 \\
\hline United States, 1974-1995 & 3.7 & 3.7 & -0.6 & 0.6 & 0.8 & 1.8 & 1.0 & -0.9 & 1.8 & -1.5 & 0.2 & -2.2 & 2.6 \\
\hline
\end{tabular}

Note: See Annex 1, Section 7.3 for the methodology.

Source: OECD. 
Table 5.1. Trends in poverty using a relative threshold, mid-1970s to mid-1990s ${ }^{1}$

Equivalence scale elasticity $=0.5$

Changes in percentage points, unless otherwise indicated

\begin{tabular}{|c|c|c|c|c|c|c|}
\hline & \multicolumn{6}{|c|}{ Mid-1970s to mid-1990s } \\
\hline & $\begin{array}{c}40 \% \\
\text { median }\end{array}$ & \multicolumn{4}{|c|}{$50 \%$ median income } & \multirow{3}{*}{$\begin{array}{c}60 \% \\
\text { median } \\
\text { income } \\
\begin{array}{c}\text { Head-count } \\
\text { ratio }\end{array} \\
\end{array}$} \\
\hline & \multirow{2}{*}{$\begin{array}{c}\text { Head-count } \\
\text { ratio }\end{array}$} & \multirow{2}{*}{$\begin{array}{c}\text { Head-count } \\
\text { ratio }\end{array}$} & \multirow{2}{*}{$\begin{array}{c}\text { Income gap } \\
\text { ratio }\end{array}$} & \multicolumn{2}{|c|}{ Change in Sen index ${ }^{2}$} & \\
\hline & & & & Per cent & Absolute & \\
\hline Australia, 1975/76-93/94 & -1.6 & -2.4 & 2.1 & -8.2 & -0.4 & 1.6 \\
\hline Belgium & .. & .. & .. & .. & .. & .. \\
\hline Canada, 1975-94 & -1.4 & -2.3 & -3.0 & -28.8 & -1.4 & -2.5 \\
\hline Denmark & .. & .. & .. &.. & .. &.. \\
\hline Finland & .. & .. & .. & .. & .. & .. \\
\hline France & .. & .. & .. & .. & .. & .. \\
\hline Germany & .. & .. & .. & .. & .. & .. \\
\hline Italy & .. & .. & .. & .. & .. & .. \\
\hline Japan & .. & .. & .. & .. &.. & .. \\
\hline Netherlands, 1977-94 & 1.8 & 3.7 & -2.2 & 132.2 & 1.6 & 7.7 \\
\hline Norway & .. &.. &.. & .. & .. &.. \\
\hline Sweden, 1975-95 & 1.4 & -0.2 & 10.4 & 17.2 & 0.5 & -2.2 \\
\hline \multirow[t]{5}{*}{ United States, 1974-95 } & 0.9 & 1.6 & -0.3 & 9.5 & 0.7 & 2.7 \\
\hline & \multicolumn{6}{|c|}{ Mid-1980s to mid-1990s } \\
\hline & $\begin{array}{c}40 \% \\
\text { median } \\
\text { income }\end{array}$ & \multicolumn{4}{|c|}{$50 \%$ median income } & $\begin{array}{c}60 \% \\
\text { median } \\
\text { income }\end{array}$ \\
\hline & Head-count & Head-count & Income gap & \multicolumn{2}{|c|}{ Change in Sen index ${ }^{2}$} & Head-count \\
\hline & ratio & ratio & ratio & Per cent & Absolute & ratio \\
\hline Australia, 1984-1993/94 & 0.0 & -2.7 & 5.0 & -4.2 & -0.2 & -1.4 \\
\hline Belgium, 1983-1995 & -1.4 & -2.8 & 1.1 & -27.1 & -1.3 & -2.3 \\
\hline Canada, 1985-1994 & -0.8 & -0.8 & -1.4 & -12.8 & -0.5 & -1.5 \\
\hline Denmark, 1993-1994 & -1.0 & -2.0 & -0.8 & -31.3 & -0.9 & -3.0 \\
\hline Finland, 1986-1995 & -0.3 & -0.2 & -4.2 & -20.4 & -0.4 & 0.0 \\
\hline France, 1979-1990 & -1.1 & -1.5 & -4.9 & -31.3 & -1.1 & -0.9 \\
\hline Germany, 1984-1994 & 1.8 & 2.9 & 2.5 & 20.8 & 0.4 & 3.8 \\
\hline Italy, 1984-1993 & 2.7 & 3.9 & 5.6 & 66.0 & 2.9 & 4.9 \\
\hline Japan, 1984-1994 & 0.6 & 0.8 & 2.5 & 23.1 & 0.6 & 1.0 \\
\hline Netherlands, 1985-1994 & 1.3 & 3.0 & -3.6 & 79.4 & 1.1 & 6.2 \\
\hline Norway, 1986-1995 & 1.4 & 1.1 & .. & 55.4 & 0.6 & 1.7 \\
\hline Sweden, 1983-1995 & 0.9 & 0.4 & 7.9 & 23.7 & 0.8 & 0.4 \\
\hline United States, 1985-95 & -1.2 & -1.2 & 0.2 & -4.9 & -0.4 & -0.1 \\
\hline
\end{tabular}

1. "Relative threshold" poverty lines are fixed in terms of real median income in each period.

2. Absolute change is the difference in the value of the index.

Source: OECD. 
Table 5.2. Trends in poverty using a constant threshold: mid-1970s to mid-1990s ${ }^{1}$

Equivalence scale elasticity $=0.5$

Changes in percentage points, unless otherwise indicated

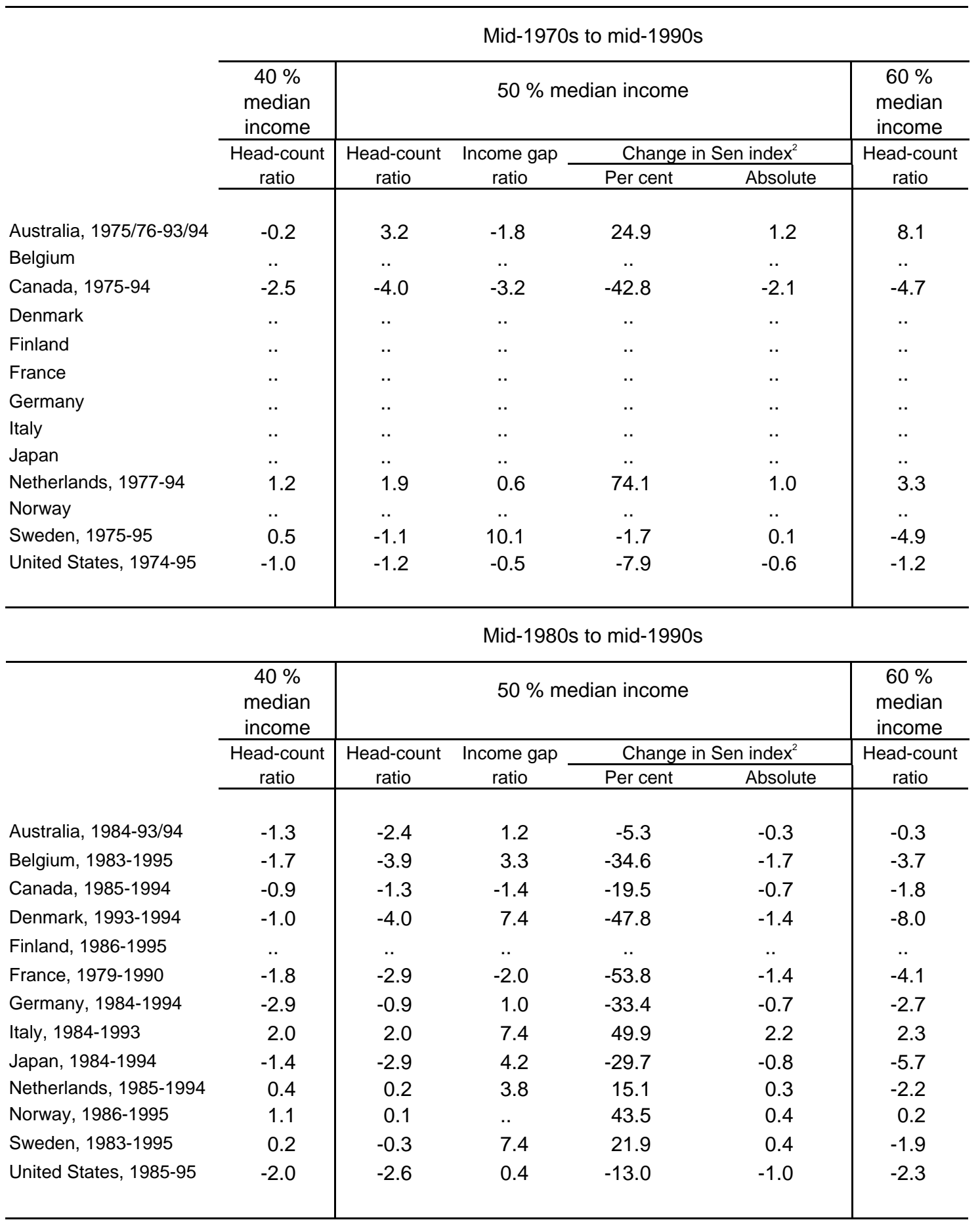

1. "Constant threshold" poverty lines are fixed in terms of real median income in the earliest period.

2. Absolute change is the difference in the value of the index.

Source: OECD. 
Table 5.3. Poverty rates and poverty structure after taxes and transfers ${ }^{1,2}$

Equivalence scale elasticity $=0.5$

Per cent, and changes in percentage points

\begin{tabular}{|c|c|c|c|c|c|c|c|c|c|c|c|c|c|c|c|c|}
\hline & \multicolumn{10}{|c|}{ Households with no workers } & \multicolumn{6}{|c|}{ One-worker households } \\
\hline & \multicolumn{2}{|c|}{$\begin{array}{c}\text { All non-working } \\
\text { households }\end{array}$} & \multicolumn{2}{|c|}{ Young head } & \multicolumn{2}{|c|}{$\begin{array}{c}\text { Retirement-age } \\
\text { head }^{3}\end{array}$} & \multicolumn{2}{|c|}{$\begin{array}{c}\text { Single adult } \\
\text { children }\end{array}$} & \multicolumn{2}{|c|}{ Two adults children } & \multicolumn{2}{|c|}{$\begin{array}{c}\text { All one-worker } \\
\text { household }\end{array}$} & \multicolumn{2}{|c|}{$\begin{array}{c}\text { Single adult } \\
\text { children }\end{array}$} & \multicolumn{2}{|c|}{ Young adult head } \\
\hline & rate & share & rate & share & rate & share & rate & share & rate & share & rate & share & rate & share & rate & share \\
\hline $\begin{array}{l}\text { Australia, proportion in 1993/94 } \\
\text { Changes, 1975/76-1993/94 }\end{array}$ & $\begin{array}{r}61.1 \\
-14.9\end{array}$ & $\begin{array}{l}67.2 \\
23.9\end{array}$ & $\begin{array}{r}83.7 \\
-8.7\end{array}$ & $\begin{array}{l}8.8 \\
5.6\end{array}$ & $\begin{array}{r}50.7 \\
-20.9\end{array}$ & $\begin{array}{r}25.9 \\
4.4\end{array}$ & $\begin{array}{r}86.8 \\
-7.4\end{array}$ & $\begin{array}{r}12.2 \\
7.4\end{array}$ & $\begin{array}{l}69.5 \\
-8.7\end{array}$ & $\begin{array}{r}14.6 \\
5.6\end{array}$ & $\begin{array}{l}14.0 \\
-7.4\end{array}$ & $\begin{array}{r}20.1 \\
-21.5\end{array}$ & $\begin{array}{r}25.8 \\
8.4\end{array}$ & $\begin{array}{l}3.2 \\
1.7\end{array}$ & $\begin{array}{l}15.3 \\
-3.6\end{array}$ & $\begin{array}{r}3.2 \\
-5.6\end{array}$ \\
\hline $\begin{array}{l}\text { Belgium, proportion in } 1995 \\
\text { Changes, 1983-1995 }\end{array}$ & $\begin{array}{l}. . \\
. .\end{array}$ & $\begin{array}{l}. . \\
. .\end{array}$ & $\begin{array}{l}. . \\
. .\end{array}$ & $\begin{array}{l}. . \\
. .\end{array}$ & $\begin{array}{l}. . \\
. .\end{array}$ & $\begin{array}{l}. . \\
. .\end{array}$ & $\begin{array}{l}74.4 \\
. .\end{array}$ & $\begin{array}{l}2.5 \\
. .\end{array}$ & $\begin{array}{c}64.4 \\
. .\end{array}$ & $\begin{array}{l}5.3 \\
. .\end{array}$ & $\begin{array}{l}. . \\
. .\end{array}$ & $\begin{array}{l}. . \\
. .\end{array}$ & $\begin{array}{l}29.7 \\
. .\end{array}$ & $\begin{array}{l}5.6 \\
. .\end{array}$ & $\begin{array}{l}. . \\
. .\end{array}$ & $\begin{array}{l}. . \\
. .\end{array}$ \\
\hline $\begin{array}{c}\text { Denmark, proportion in } 1994 \\
\text { Changes, 1983-1994 }\end{array}$ & $\begin{array}{r}55.1 \\
-3.7\end{array}$ & $\begin{array}{r}63.2 \\
-0.1\end{array}$ & $\begin{array}{r}78.0 \\
-3.0\end{array}$ & $\begin{array}{l}4.9 \\
1.4\end{array}$ & $\begin{array}{r}58.3 \\
-4.7\end{array}$ & $\begin{array}{r}43.2 \\
-0.8\end{array}$ & $\begin{array}{r}92.7 \\
5.2\end{array}$ & $\begin{array}{l}6.3 \\
2.3\end{array}$ & $\begin{array}{r}54.6 \\
5.7\end{array}$ & $\begin{array}{r}4.8 \\
-1.2\end{array}$ & $\begin{array}{r}24.2 \\
0.9\end{array}$ & $\begin{array}{r}29.7 \\
-0.2\end{array}$ & $\begin{array}{l}56.1 \\
10.5\end{array}$ & $\begin{array}{r}10.0 \\
2.2\end{array}$ & $\begin{array}{l}46.3 \\
11.0\end{array}$ & $\begin{array}{r}13.0 \\
3.2\end{array}$ \\
\hline $\begin{array}{r}\text { Finland, proportion in } 1995 \\
\text { Changes, 1986-1995 }\end{array}$ & $\begin{array}{r}52.1 \\
-6.5\end{array}$ & $\begin{array}{l}48.7 \\
11.2\end{array}$ & $\begin{array}{r}89.3 \\
-1.5\end{array}$ & $\begin{array}{l}5.4 \\
4.4\end{array}$ & $\begin{array}{r}46.8 \\
-10.1\end{array}$ & $\begin{array}{r}29.9 \\
0.7\end{array}$ & $\begin{array}{r}62.1 \\
-11.5\end{array}$ & $\begin{array}{l}4.3 \\
3.2\end{array}$ & $\begin{array}{l}52.7 \\
16.9\end{array}$ & $\begin{array}{l}1.6 \\
1.2\end{array}$ & $\begin{array}{r}26.8 \\
-5.8\end{array}$ & $\begin{array}{r}25.6 \\
-8.4\end{array}$ & $\begin{array}{r}23.3 \\
-11.7\end{array}$ & $\begin{array}{r}4.8 \\
-0.8\end{array}$ & $\begin{array}{r}49.6 \\
0.5\end{array}$ & $\begin{array}{r}10.4 \\
-4.3\end{array}$ \\
\hline $\begin{array}{r}\text { France, proportion in } 1990 \\
\text { Changes, 1979-1990 }\end{array}$ & $\begin{array}{r}30.9 \\
-3.9\end{array}$ & $\begin{array}{r}32.7 \\
1.0\end{array}$ & $\begin{array}{l}88.9 \\
12.8\end{array}$ & $\begin{array}{l}2.3 \\
1.8\end{array}$ & $\begin{array}{r}24.9 \\
-6.8\end{array}$ & $\begin{array}{l}16.8 \\
-3.7\end{array}$ & $\begin{array}{l}76.4 \\
12.8\end{array}$ & $\begin{array}{l}5.7 \\
3.0\end{array}$ & $\begin{array}{r}37.1 \\
-7.5\end{array}$ & $\begin{array}{r}4.4 \\
-0.5\end{array}$ & $\begin{array}{r}27.1 \\
4.1\end{array}$ & $\begin{array}{r}55.7 \\
-2.2\end{array}$ & $\begin{array}{r}36.4 \\
8.1\end{array}$ & $\begin{array}{l}8.7 \\
4.0\end{array}$ & $\begin{array}{l}39.7 \\
11.1\end{array}$ & $\begin{array}{l}9.5 \\
1.7\end{array}$ \\
\hline $\begin{array}{c}\text { Germany, proportion in } 1994 \\
\text { Changes, 1984-1994 }\end{array}$ & $\begin{array}{r}39.5 \\
-3.9\end{array}$ & $\begin{array}{r}51.5 \\
3.1\end{array}$ & $\begin{array}{r}84.9 \\
-0.3\end{array}$ & $\begin{array}{l}7.6 \\
1.3\end{array}$ & $\begin{array}{r}26.0 \\
-10.4\end{array}$ & $\begin{array}{r}21.8 \\
-3.6\end{array}$ & $\begin{array}{r}81.8 \\
-9.7\end{array}$ & $\begin{array}{l}5.3 \\
2.1\end{array}$ & $\begin{array}{l}78.7 \\
22.1\end{array}$ & $\begin{array}{l}9.8 \\
2.8\end{array}$ & $\begin{array}{r}20.2 \\
-0.1\end{array}$ & $\begin{array}{r}41.7 \\
-0.4\end{array}$ & $\begin{array}{r}51.0 \\
2.4\end{array}$ & $\begin{array}{l}4.3 \\
2.2\end{array}$ & $\begin{array}{r}35.1 \\
0.9\end{array}$ & $\begin{array}{l}9.0 \\
0.6\end{array}$ \\
\hline $\begin{array}{l}\text { Italy, proportion in } 1993 \\
\text { Changes, } 1984-1993\end{array}$ & $\begin{array}{r}37.5 \\
-11.2\end{array}$ & $\begin{array}{r}38.9 \\
5.7\end{array}$ & $\begin{array}{r}80.2 \\
-19.8\end{array}$ & $\begin{array}{l}1.2 \\
1.2\end{array}$ & $\begin{array}{r}29.0 \\
-17.7\end{array}$ & $\begin{array}{r}18.1 \\
-2.9\end{array}$ & $\begin{array}{r}79.7 \\
-14.8\end{array}$ & $\begin{array}{l}2.0 \\
1.5\end{array}$ & $\begin{array}{r}75.8 \\
1.6\end{array}$ & $\begin{array}{l}8.7 \\
5.4\end{array}$ & $\begin{array}{r}24.3 \\
-0.9\end{array}$ & $\begin{array}{r}49.6 \\
-8.9\end{array}$ & $\begin{array}{l}40.0 \\
13.4\end{array}$ & $\begin{array}{l}1.4 \\
0.7\end{array}$ & $\begin{array}{r}26.4 \\
-3.3\end{array}$ & $\begin{array}{r}3.3 \\
-0.9\end{array}$ \\
\hline $\begin{array}{l}\text { Japan, proportion in } 1994 \\
\text { Changes, } 1984-1994\end{array}$ & $\begin{array}{r}42.5 \\
-13.4\end{array}$ & $\begin{array}{r}20.1 \\
6.7\end{array}$ & $\begin{array}{l}87.6 \\
13.9\end{array}$ & $\begin{array}{l}0.2 \\
0.0\end{array}$ & $\begin{array}{r}39.4 \\
-11.8\end{array}$ & $\begin{array}{r}15.0 \\
6.6\end{array}$ & $\begin{array}{r}70.6 \\
-23.8\end{array}$ & $\begin{array}{r}0.3 \\
-0.4\end{array}$ & $\begin{array}{r}70.3 \\
6.7\end{array}$ & $\begin{array}{r}0.7 \\
-0.1\end{array}$ & $\begin{array}{r}23.0 \\
2.8\end{array}$ & $\begin{array}{r}44.8 \\
2.5\end{array}$ & $\begin{array}{l}67.1 \\
14.9\end{array}$ & $\begin{array}{l}1.6 \\
0.1\end{array}$ & $\begin{array}{r}38.9 \\
7.8\end{array}$ & $\begin{array}{l}7.4 \\
0.0\end{array}$ \\
\hline $\begin{array}{l}\text { Netherlands, proportion in } 1994 \\
\text { Changes, 1977-1994 }\end{array}$ & $\begin{array}{r}47.1 \\
4.1\end{array}$ & $\begin{array}{l}60.3 \\
25.3\end{array}$ & $\begin{array}{l}91.7 \\
10.3\end{array}$ & $\begin{array}{l}9.2 \\
6.3\end{array}$ & $\begin{array}{l}33.1 \\
-6.3\end{array}$ & $\begin{array}{r}21.7 \\
1.2\end{array}$ & $\begin{array}{l}89.7 \\
13.3\end{array}$ & $\begin{array}{r}10.8 \\
6.6\end{array}$ & $\begin{array}{l}81.4 \\
25.4\end{array}$ & $\begin{array}{r}11.0 \\
5.4\end{array}$ & $\begin{array}{l}18.9 \\
-5.1\end{array}$ & $\begin{array}{r}31.3 \\
-25.1\end{array}$ & $\begin{array}{r}39.4 \\
-0.3\end{array}$ & $\begin{array}{l}2.4 \\
1.6\end{array}$ & $\begin{array}{r}41.8 \\
4.9\end{array}$ & $\begin{array}{l}10.0 \\
-2.7\end{array}$ \\
\hline $\begin{array}{r}\text { Norway, proportion in } 1995 \\
\text { Changes, } 1986-1995\end{array}$ & $\begin{array}{r}63.0 \\
-6.9\end{array}$ & $\begin{array}{l}54.5 \\
16.2\end{array}$ & $\begin{array}{r}94.6 \\
-1.3\end{array}$ & $\begin{array}{r}17.0 \\
7.4\end{array}$ & $\begin{array}{r}55.0 \\
-10.2\end{array}$ & $\begin{array}{r}36.9 \\
-2.6\end{array}$ & $\begin{array}{r}83.7 \\
-11.9\end{array}$ & $\begin{array}{r}11.7 \\
3.5\end{array}$ & $\begin{array}{l}76.7 \\
12.6\end{array}$ & $\begin{array}{l}5.0 \\
3.1\end{array}$ & $\begin{array}{l}16.7 \\
-3.8\end{array}$ & $\begin{array}{r}29.0 \\
-11.0\end{array}$ & $\begin{array}{r}18.5 \\
-8.7\end{array}$ & $\begin{array}{r}3.9 \\
-0.2\end{array}$ & $\begin{array}{r}31.9 \\
1.3\end{array}$ & $\begin{array}{r}9.7 \\
-0.1\end{array}$ \\
\hline $\begin{array}{r}\text { Sweden, proportion in } 1995 \\
\text { Changes, 1975-1995 }\end{array}$ & $\begin{array}{r}38.3 \\
-18.6\end{array}$ & $\begin{array}{r}44.1 \\
-12.7\end{array}$ & $\begin{array}{r}93.3 \\
5.8\end{array}$ & $\begin{array}{r}10.1 \\
4.7\end{array}$ & $\begin{array}{r}29.8 \\
-26.6\end{array}$ & $\begin{array}{r}24.4 \\
-20.5\end{array}$ & $\begin{array}{l}66.5 \\
19.5\end{array}$ & $\begin{array}{l}3.4 \\
2.3\end{array}$ & $\begin{array}{r}58.7 \\
-21.5\end{array}$ & $\begin{array}{l}3.4 \\
2.1\end{array}$ & $\begin{array}{r}29.0 \\
8.0\end{array}$ & $\begin{array}{l}46.2 \\
13.8\end{array}$ & $\begin{array}{l}30.4 \\
17.0\end{array}$ & $\begin{array}{r}10.2 \\
6.8\end{array}$ & $\begin{array}{l}52.9 \\
19.3\end{array}$ & $\begin{array}{l}26.9 \\
10.6\end{array}$ \\
\hline $\begin{array}{l}\text { United States, proportion in } 1995 \\
\quad \text { Changes, 1974-1995 }\end{array}$ & $\begin{array}{r}50.0 \\
-11.7\end{array}$ & $\begin{array}{r}34.7 \\
1.4\end{array}$ & $\begin{array}{r}93.9 \\
-2.0\end{array}$ & $\begin{array}{l}4.8 \\
0.7\end{array}$ & $\begin{array}{r}33.4 \\
-15.5\end{array}$ & $\begin{array}{r}14.3 \\
-1.3\end{array}$ & $\begin{array}{r}94.6 \\
2.1\end{array}$ & $\begin{array}{r}8.9 \\
-0.4\end{array}$ & $\begin{array}{r}81.9 \\
-2.4\end{array}$ & $\begin{array}{l}5.8 \\
0.7\end{array}$ & $\begin{array}{r}29.3 \\
6.1\end{array}$ & $\begin{array}{r}43.1 \\
0.7\end{array}$ & $\begin{array}{r}45.5 \\
-10.8\end{array}$ & $\begin{array}{r}11.3 \\
1.8\end{array}$ & $\begin{array}{l}51.9 \\
19.1\end{array}$ & $\begin{array}{l}11.1 \\
-0.5\end{array}$ \\
\hline
\end{tabular}

1. Data are presented for selected groups only and shares do not sum to 100

2. Rate is the share of individuals belonging to a specific household who are in the bottom quintile. The share is the proportion of individuals in the bottom quintile belonging to a given group (e.g. in 1993/94, 61.1 per cent of Australians in non-working households were in the bottom quintile; these represented 67.2 per cent of the total number of individuals of the bottom quintile).

3. Mainly retired households.

Source: OECD. 


\section{Table 5.4. Poverty rates ${ }^{1}$ before taxes and transfers}

Equivalence scale elasticity $=0.5$

Per cent of poor ${ }^{2}$ individuals in each group, and changes in percentage points

\begin{tabular}{|c|c|c|c|c|c|c|c|c|c|c|c|c|c|}
\hline & \multirow{3}{*}{ Total } & \multicolumn{4}{|c|}{ By age of the household's head } & \multicolumn{4}{|c|}{ By family type } & \multicolumn{4}{|c|}{ By work attachment } \\
\hline & & \multirow{2}{*}{ Head below 30} & \multirow{2}{*}{$\begin{array}{l}\text { Head between } \\
30 \text { and } 50\end{array}$} & \multirow{2}{*}{$\begin{array}{l}\text { Head between } \\
50 \text { and } 65\end{array}$} & \multirow{2}{*}{ Head above 65} & \multicolumn{2}{|c|}{ Single-adult households } & \multicolumn{2}{|c|}{ Two-adult households ${ }^{2}$} & \multicolumn{2}{|c|}{ Non-working households } & \multicolumn{2}{|c|}{ Working households } \\
\hline & & & & & & Head below 65 & Head above 65 & Head below 65 & Head above 65 & Head below 65 & Head above 65 & Head below 65 & Head above 65 \\
\hline \multirow{2}{*}{$\begin{array}{l}\text { Canada, } 1991 \\
\quad \text { Changes, } 1975-1991\end{array}$} & 22.9 & 27.9 & 15.5 & 18.5 & 57.4 & 46.3 & 75.6 & 14.1 & 50.6 & 72.5 & 69.2 & 12.5 & 19.4 \\
\hline & 0.3 & 12.4 & 2.8 & -0.9 & -10.2 & 10.9 & -7.6 & 2.6 & -9.5 & -12.1 & -15.8 & 0.9 & -12.4 \\
\hline \multirow{2}{*}{$\begin{array}{l}\text { France, } 1989 \\
\quad \text { Changes, 1984-1989 }\end{array}$} & 34.5 & 24.1 & 20.7 & 40.1 & 84.6 & 41.0 & 95.8 & 23.8 & 79.6 & 71.9 & 92.1 & 15.1 & 29.1 \\
\hline & 1.6 & 6.2 & 2.3 & -5.2 & -2.8 & 3.0 & -0.1 & -0.1 & -4.1 & -1.0 & 3.7 & 4.0 & -2.3 \\
\hline \multirow{2}{*}{$\begin{array}{l}\text { Germany, } 1989 \\
\quad \text { Changes, 1978-1989 }\end{array}$} & 22.1 & 14.2 & 5.2 & 17.9 & 70.7 & 28.0 & 84.7 & 6.4 & 61.7 & 66.2 & 78.7 & 4.2 & 18.0 \\
\hline & 1.9 & 4.5 & 1.7 & 0.9 & 0.9 & -6.7 & 1.8 & 0.5 & -1.4 & 24.1 & 2.3 & 1.0 & -1.5 \\
\hline \multirow{2}{*}{$\begin{array}{l}\text { Sweden, } 1992 \\
\quad \text { Changes, 1975-1992 }\end{array}$} & 33.9 & 37.9 & 14.5 & 21.7 & 90.7 & 40.8 & 97.2 & 12.7 & 85.4 & 90.1 & 95.4 & 13.1 & 30.4 \\
\hline & 7.9 & 22.2 & 7.6 & 4.1 & -8.4 & 12.6 & -15.7 & 6.6 & -3.6 & 27.7 & -7.5 & 6.7 & -9.1 \\
\hline \multirow{5}{*}{$\begin{array}{l}\text { United States, } 1994 \\
\quad \text { Changes, 1974-1994 } \\
\end{array}$} & 25.3 & 31.5 & 17.4 & 18.5 & 58.1 & 45.1 & 76.9 & 15.9 & 50.9 & 71.1 & 68.2 & 14.8 & 24.1 \\
\hline & 4.5 & 11.9 & 4.8 & 1.2 & -6.7 & -7.1 & -4.4 & 4.7 & -7.9 & 10.1 & -8.0 & 4.5 & -1.7 \\
\hline & \multirow{3}{*}{ Total } & \multicolumn{4}{|c|}{ Non-working households } & \multicolumn{4}{|c|}{ Working households } & \multirow{2}{*}{\multicolumn{4}{|c|}{ Total households }} \\
\hline & & \multicolumn{2}{|c|}{ With children } & \multicolumn{2}{|c|}{ No children } & \multicolumn{2}{|c|}{ With children } & \multicolumn{2}{|c|}{ No children } & & & & \\
\hline & & Single adult & $\begin{array}{l}\text { Two adults } \\
\text { or more }\end{array}$ & Single adult & $\begin{array}{l}\text { Two adults } \\
\text { or more }\end{array}$ & Single adult & $\begin{array}{l}\text { Two adults } \\
\text { or more }\end{array}$ & Single adult & $\begin{array}{l}\text { Two adults } \\
\text { or more }\end{array}$ & With cr & hildren & No ch & hildren \\
\hline Canada, 1991 & 22.9 & 96.4 & 67.9 & 75.4 & 62.7 & 44.3 & 12.6 & 20.6 & 8.5 & 19 & 9.7 & & 6.4 \\
\hline Changes, 1975-1991 & 0.3 & -0.4 & -28.7 & -11.9 & -17.3 & -1.3 & 1.1 & -1.8 & -1.6 & & $t .9$ & & 3.8 \\
\hline France, 1989 & 34.5 & 95.9 & 62.1 & 89.7 & 83.5 & 25.9 & 18.7 & 3.2 & 9.3 & 25 & 5.9 & & 4.8 \\
\hline Changes, 1984-1989 & 1.6 & 0.6 & -7.9 & -1.7 & 5.7 & 6.0 & 4.9 & -0.8 & 3.8 & & 2.8 & & 0.2 \\
\hline Germany, 1989 & 22.1 & 78.9 & 39.1 & 80.6 & 72.8 & 14.9 & 3.1 & 9.2 & 4.8 & & .5 & & 2.9 \\
\hline Changes, 1978-1989 & 1.9 & 1.4 & 14.5 & -0.4 & 5.4 & -2.7 & 1.0 & 0.9 & 0.1 & & .8 & & 7.7 \\
\hline Sweden, 1992 & 33.9 & 93.2 & 88.3 & 95.7 & 92.0 & 27.6 & 9.6 & 26.5 & 9.9 & 16 & 3.3 & & 8.1 \\
\hline Changes, 1975-1992 & 7.9 & 2.6 & 60.8 & -3.9 & 3.8 & 12.2 & 5.5 & 12.4 & 3.4 & & 3.9 & & 4.2 \\
\hline United States, 1994 & 25.3 & 95.1 & 70.8 & 74.1 & 59.8 & 48.0 & 15.4 & 12.9 & 8.8 & 24 & 4.0 & & 7.0 \\
\hline Changes, 1974-1994 & 4.5 & -1.2 & 22.9 & -5.8 & -6.9 & -5.6 & 5.7 & -0.8 & 1.9 & & .9 & & 0.6 \\
\hline
\end{tabular}

Poverty rate by group is the number of "poor" individuals in a group as a per cent of the total number of individuals in that group.

2. "Poor" are individuals with equivalent income below 50 per cent of median equivalent disposable income.

Source: Luxembourg Income Study. 


\section{Table 5.5. Structure of poverty ${ }^{1}$ before taxes and transfers}

Equivalence scale elasticity $=0.5$

Per cent of all poor ${ }^{2}$ individuals belonging to each group, and changes in percentage points

\begin{tabular}{|c|c|c|c|c|c|c|c|c|c|c|c|c|c|}
\hline \multirow{4}{*}{ Canada, 1991 - } & \multirow{4}{*}{$\begin{array}{c}\text { Total } \\
100\end{array}$} & \multicolumn{4}{|c|}{ By age of the household's head } & \multicolumn{4}{|c|}{ By family type } & \multicolumn{4}{|c|}{ By work attachment } \\
\hline & & \multirow{2}{*}{ Head below 30} & \multirow{2}{*}{$\begin{array}{l}\text { Head between } \\
30 \text { and } 50\end{array}$} & \multirow{2}{*}{$\begin{array}{l}\text { Head between } \\
50 \text { and } 65\end{array}$} & \multirow{2}{*}{ Head above 65} & \multicolumn{2}{|c|}{ Single-adult households } & \multicolumn{2}{|c|}{ Two-adult households ${ }^{2}$} & \multicolumn{2}{|c|}{ Non-working households } & \multicolumn{2}{|c|}{ Working households } \\
\hline & & & & & & Head below 65 & Head above 65 & Head below 65 & Head above 65 & Head below 65 & Head above 65 & Head below 65 & Head above 65 \\
\hline & & $\begin{array}{r}19.6 \\
2.9\end{array}$ & $\begin{array}{l}36.2 \\
14.0\end{array}$ & $\begin{array}{l}15.6 \\
-3.6\end{array}$ & $\begin{array}{r}28.7 \\
-13.3\end{array}$ & $\begin{array}{r}24.5 \\
3.2\end{array}$ & $\begin{array}{l}10.3 \\
-6.3\end{array}$ & $\begin{array}{l}46.8 \\
10.1\end{array}$ & $\begin{array}{r}18.4 \\
-6.9\end{array}$ & $\begin{array}{l}27.9 \\
12.2\end{array}$ & $\begin{array}{r}26.4 \\
-9.1\end{array}$ & $\begin{array}{r}43.4 \\
1.1\end{array}$ & $\begin{array}{r}2.3 \\
-4.2\end{array}$ \\
\hline $\begin{array}{l}\text { France, } 1989 \\
\quad \text { Changes, 1984-1989 }\end{array}$ & 100 & $\begin{array}{l}9.4 \\
0.7\end{array}$ & $\begin{array}{r}30.4 \\
2.8\end{array}$ & $\begin{array}{l}25.1 \\
-6.1\end{array}$ & $\begin{array}{r}35.1 \\
2.6\end{array}$ & $\begin{array}{r}10.8 \\
2.1\end{array}$ & $\begin{array}{r}12.2 \\
1.4\end{array}$ & $\begin{array}{r}54.1 \\
-4.7\end{array}$ & $\begin{array}{r}22.9 \\
1.2\end{array}$ & $\begin{array}{l}34.7 \\
-9.8\end{array}$ & $\begin{array}{r}33.7 \\
1.3\end{array}$ & $\begin{array}{r}30.2 \\
7.2\end{array}$ & $\begin{array}{l}1.4 \\
1.2\end{array}$ \\
\hline $\begin{array}{l}\text { Germany, } 1989 \\
\quad \text { Changes, } 1978-1989\end{array}$ & 100 & $\begin{array}{l}7.2 \\
3.9\end{array}$ & $\begin{array}{r}10.3 \\
1.7\end{array}$ & $\begin{array}{r}21.2 \\
0.1\end{array}$ & $\begin{array}{r}61.3 \\
-5.8\end{array}$ & $\begin{array}{r}16.3 \\
4.2\end{array}$ & $\begin{array}{r}28.8 \\
1.7\end{array}$ & $\begin{array}{r}22.5 \\
1.5\end{array}$ & $\begin{array}{r}32.5 \\
-7.5\end{array}$ & $\begin{array}{r}25.2 \\
1.5\end{array}$ & $\begin{array}{r}59.2 \\
-5.7\end{array}$ & $\begin{array}{r}13.5 \\
4.3\end{array}$ & $\begin{array}{r}2.0 \\
-0.1\end{array}$ \\
\hline $\begin{array}{l}\text { Sweden, } 1992 \\
\quad \text { Changes, 1975-1992 }\end{array}$ & 100 & $\begin{array}{r}22.4 \\
9.1\end{array}$ & $\begin{array}{r}19.6 \\
8.7\end{array}$ & $\begin{array}{l}10.5 \\
-3.4\end{array}$ & $\begin{array}{r}47.5 \\
-14.3\end{array}$ & $\begin{array}{r}32.0 \\
8.2\end{array}$ & $\begin{array}{r}22.7 \\
-6.8\end{array}$ & $\begin{array}{r}20.6 \\
6.1\end{array}$ & $\begin{array}{r}24.7 \\
-7.5\end{array}$ & $\begin{array}{r}21.6 \\
2.4\end{array}$ & $\begin{array}{r}46.3 \\
-13.9\end{array}$ & $\begin{array}{l}30.9 \\
11.9\end{array}$ & $\begin{array}{r}1.2 \\
-0.4\end{array}$ \\
\hline \multirow[t]{4}{*}{$\begin{array}{l}\text { United States, } 1994 \\
\text { Changes, 1974-1994 } \\
\end{array}$} & 100 & $\begin{array}{r}19.4 \\
0.0 \\
\end{array}$ & $\begin{array}{r}36.2 \\
8.1\end{array}$ & $\begin{array}{l}13.3 \\
-4.9 \\
\end{array}$ & $\begin{array}{l}31.0 \\
-3.2 \\
\end{array}$ & $\begin{array}{r}22.5 \\
-0.1 \\
\end{array}$ & $\begin{array}{l}11.3 \\
-0.1 \\
\end{array}$ & $\begin{array}{r}46.5 \\
3.4 \\
\end{array}$ & $\begin{array}{r}19.8 \\
-3.2 \\
\end{array}$ & $\begin{array}{r}23.4 \\
-2.8 \\
\end{array}$ & $\begin{array}{r}28.1 \\
-3.1 \\
\end{array}$ & $\begin{array}{r}45.6 \\
6.0 \\
\end{array}$ & $\begin{array}{r}3.0 \\
-0.1 \\
\end{array}$ \\
\hline & \multirow{3}{*}{ Total } & \multicolumn{4}{|c|}{ Non-working households } & \multicolumn{4}{|c|}{ Working households } & \multirow{2}{*}{\multicolumn{4}{|c|}{ Total households }} \\
\hline & & \multicolumn{2}{|c|}{ With children } & \multicolumn{2}{|c|}{ No children } & \multicolumn{2}{|c|}{ With children } & \multicolumn{2}{|c|}{ No children } & & & & \\
\hline & & Single adult & $\begin{array}{l}\text { Two adults } \\
\text { or more }\end{array}$ & Single adult & $\begin{array}{l}\text { Two adults } \\
\text { or more }\end{array}$ & Single adult & $\begin{array}{l}\text { Two adults } \\
\text { or more }\end{array}$ & Single adult & $\begin{array}{l}\text { Two adults } \\
\text { or more }\end{array}$ & With c & hildren & \multicolumn{2}{|c|}{ No children } \\
\hline $\begin{array}{l}\text { Canada, } 1991 \\
\quad \text { Changes, 1975-1991 }\end{array}$ & 100 & $\begin{array}{l}8.0 \\
4.6\end{array}$ & $\begin{array}{l}7.7 \\
4.7\end{array}$ & $\begin{array}{l}16.8 \\
-4.8\end{array}$ & $\begin{array}{r}21.7 \\
-1.4\end{array}$ & $\begin{array}{l}4.7 \\
2.4\end{array}$ & $\begin{array}{r}25.4 \\
1.8\end{array}$ & $\begin{array}{r}5.2 \\
-5.3\end{array}$ & $\begin{array}{r}10.4 \\
-2.0\end{array}$ & $\begin{array}{l}45 \\
13\end{array}$ & 5.8 & $\begin{array}{r}54 \\
-13\end{array}$ & $\begin{array}{l}4.2 \\
3.6\end{array}$ \\
\hline $\begin{array}{l}\text { France, } 1989 \\
\quad \text { Changes, 1984-1989 }\end{array}$ & 100 & $\begin{array}{l}3.3 \\
1.3\end{array}$ & $\begin{array}{l}11.9 \\
-4.7\end{array}$ & $\begin{array}{r}18.0 \\
1.8\end{array}$ & $\begin{array}{r}35.2 \\
-6.8\end{array}$ & $\begin{array}{l}1.4 \\
0.5\end{array}$ & $\begin{array}{r}24.4 \\
5.6\end{array}$ & $\begin{array}{r}0.3 \\
-0.1\end{array}$ & $\begin{array}{l}5.5 \\
2.4\end{array}$ & $\begin{array}{r}41 \\
2\end{array}$ & $\begin{array}{l}1.1 \\
2.7\end{array}$ & & $\begin{array}{l}3.9 \\
2.7\end{array}$ \\
\hline $\begin{array}{l}\text { Germany, } 1989 \\
\quad \text { Changes, 1978-1989 }\end{array}$ & 100 & $\begin{array}{l}3.6 \\
0.5\end{array}$ & $\begin{array}{r}2.3 \\
-5.0\end{array}$ & $\begin{array}{r}37.3 \\
3.6\end{array}$ & $\begin{array}{r}41.3 \\
-3.4\end{array}$ & $\begin{array}{l}1.0 \\
0.0\end{array}$ & $\begin{array}{l}5.1 \\
0.0\end{array}$ & $\begin{array}{l}3.2 \\
1.9\end{array}$ & $\begin{array}{l}6.2 \\
2.4\end{array}$ & $\begin{array}{l}12 \\
-4\end{array}$ & $\begin{array}{l}2.0 \\
1.5\end{array}$ & & $\begin{array}{l}3.0 \\
4.5\end{array}$ \\
\hline $\begin{array}{l}\text { Sweden, } 1992 \\
\quad \text { Changes, 1975-1992 }\end{array}$ & 100 & $\begin{array}{l}3.3 \\
0.2\end{array}$ & $\begin{array}{l}3.4 \\
1.6\end{array}$ & $\begin{array}{r}34.8 \\
-5.8\end{array}$ & $\begin{array}{r}26.4 \\
-7.5\end{array}$ & $\begin{array}{l}4.5 \\
2.1\end{array}$ & $\begin{array}{r}10.4 \\
3.6\end{array}$ & $\begin{array}{r}12.1 \\
5.0\end{array}$ & $\begin{array}{l}5.2 \\
0.9\end{array}$ & $\begin{array}{r}21 \\
7\end{array}$ & $\begin{array}{l}1.6 \\
7.5\end{array}$ & & $\begin{array}{l}8.4 \\
7.5\end{array}$ \\
\hline $\begin{array}{l}\text { United States, } 1994 \\
\quad \text { Changes, 1974-1994 } \\
\end{array}$ & 100 & $\begin{array}{r}8.3 \\
-1.5 \\
\end{array}$ & $\begin{array}{r}8.7 \\
-1.2 \\
\end{array}$ & $\begin{array}{r}14.4 \\
0.1 \\
\end{array}$ & $\begin{array}{l}20.1 \\
-3.3 \\
\end{array}$ & $\begin{array}{l}8.7 \\
0.7 \\
\end{array}$ & $\begin{array}{r}29.0 \\
3.3 \\
\end{array}$ & $\begin{array}{l}2.3 \\
0.4 \\
\end{array}$ & $\begin{array}{l}8.5 \\
1.5 \\
\end{array}$ & $\begin{array}{r}54 \\
1 \\
\end{array}$ & $\begin{array}{l}4.7 \\
.4\end{array}$ & & $\begin{array}{l}5.3 \\
1.4\end{array}$ \\
\hline
\end{tabular}

1. The structure of poverty is the number of "poor" individuals in each group as a per cent of all "poor" individuals.

2. "Poor" are individuals with equivalent income below 50 per cent of median equivalent disposable income.

Source: Luxembourg Income Study. 


\section{Table 5.6. Population structure}

ECO/WKP(98)2

Equivalence scale elasticity $=0.5$

Per cent of total population in each group, and changes in percentage points

\begin{tabular}{|c|c|c|c|c|c|c|c|c|c|c|c|c|c|}
\hline & \multirow{3}{*}{ Total } & \multicolumn{4}{|c|}{ By age of the household's head } & \multicolumn{4}{|c|}{ By family type } & \multicolumn{4}{|c|}{ By work attachment } \\
\hline & & \multirow{2}{*}{ Head below 30} & \multirow{2}{*}{$\begin{array}{l}\text { Head between } \\
30 \text { and } 50\end{array}$} & \multirow{2}{*}{$\begin{array}{l}\text { Head between } \\
50 \text { and } 65\end{array}$} & \multirow{2}{*}{ Head above 65} & \multicolumn{2}{|c|}{ Single-adult households } & \multicolumn{2}{|c|}{ Two-adult households } & \multicolumn{2}{|c|}{ Non-working households } & \multicolumn{2}{|c|}{ Working households } \\
\hline & & & & & & Head below 65 & Head above 65 & Head below 65 & Head above 65 & Head below 65 & 5 Head above 65 & Head below 65 & Head above 65 \\
\hline $\begin{array}{l}\text { Canada, } 1991 \\
\quad \text { Changes, } 1975-1991\end{array}$ & 100 & $\begin{array}{r}16.0 \\
-8.3\end{array}$ & $\begin{array}{l}53.2 \\
14.0\end{array}$ & $\begin{array}{r}19.2 \\
-3.0\end{array}$ & $\begin{array}{r}11.4 \\
-2.6\end{array}$ & $\begin{array}{r}12.1 \\
-1.5\end{array}$ & $\begin{array}{r}3.1 \\
-1.4\end{array}$ & $\begin{array}{r}76.3 \\
4.2\end{array}$ & $\begin{array}{r}8.3 \\
-1.2\end{array}$ & $\begin{array}{l}8.8 \\
4.6\end{array}$ & $\begin{array}{r}8.7 \\
-0.7\end{array}$ & $\begin{array}{r}79.6 \\
-1.9\end{array}$ & $\begin{array}{r}2.7 \\
-1.9\end{array}$ \\
\hline $\begin{array}{l}\text { France, } 1989 \\
\quad \text { Changes, 1984-1989 }\end{array}$ & 100 & $\begin{array}{r}13.4 \\
-2.6\end{array}$ & $\begin{array}{r}50.6 \\
1.6\end{array}$ & $\begin{array}{r}21.6 \\
-1.0\end{array}$ & $\begin{array}{r}14.3 \\
2.1\end{array}$ & $\begin{array}{l}9.1 \\
1.6\end{array}$ & $\begin{array}{l}4.4 \\
0.7\end{array}$ & $\begin{array}{l}76.5 \\
-3.6\end{array}$ & $\begin{array}{l}9.9 \\
1.4\end{array}$ & $\begin{array}{r}16.6 \\
-3.4\end{array}$ & $\begin{array}{r}12.6 \\
0.6\end{array}$ & $\begin{array}{r}69.0 \\
1.4\end{array}$ & $\begin{array}{l}1.7 \\
1.5\end{array}$ \\
\hline $\begin{array}{l}\text { Germany, } 1989 \\
\quad \text { Changes, 1978-1989 }\end{array}$ & 100 & $\begin{array}{r}11.1 \\
4.4\end{array}$ & $\begin{array}{r}43.4 \\
-5.3\end{array}$ & $\begin{array}{r}26.2 \\
1.0\end{array}$ & $\begin{array}{r}19.1 \\
-0.3\end{array}$ & $\begin{array}{r}12.8 \\
5.8\end{array}$ & $\begin{array}{l}7.5 \\
0.9\end{array}$ & $\begin{array}{r}67.9 \\
-5.7\end{array}$ & $\begin{array}{r}11.6 \\
-1.2\end{array}$ & $\begin{array}{r}8.4 \\
-3.0\end{array}$ & $\begin{array}{r}16.6 \\
-0.6\end{array}$ & $\begin{array}{r}72.3 \\
3.1\end{array}$ & $\begin{array}{l}2.5 \\
0.3\end{array}$ \\
\hline $\begin{array}{l}\text { Sweden, } 1992 \\
\quad \text { Changes, 1975-1992 }\end{array}$ & 100 & $\begin{array}{r}20.0 \\
-2.0\end{array}$ & $\begin{array}{r}45.8 \\
4.3\end{array}$ & $\begin{array}{r}16.3 \\
-4.2\end{array}$ & $\begin{array}{r}17.7 \\
1.5\end{array}$ & $\begin{array}{r}26.5 \\
4.6\end{array}$ & $\begin{array}{l}7.9 \\
1.1\end{array}$ & $\begin{array}{r}55.6 \\
-6.5\end{array}$ & $\begin{array}{l}9.8 \\
0.4\end{array}$ & $\begin{array}{l}8.1 \\
0.1\end{array}$ & $\begin{array}{r}16.4 \\
1.2\end{array}$ & $\begin{array}{r}74.0 \\
-2.0\end{array}$ & $\begin{array}{l}1.3 \\
0.3\end{array}$ \\
\hline \multirow[t]{4}{*}{ Changes, 1974-1994 } & 100 & $\begin{array}{r}15.6 \\
-5.0\end{array}$ & $\begin{array}{r}52.6 \\
6.2\end{array}$ & $\begin{array}{r}18.2 \\
-3.7\end{array}$ & $\begin{array}{r}13.5 \\
2.5\end{array}$ & $\begin{array}{r}12.6 \\
3.6\end{array}$ & $\begin{array}{l}3.7 \\
0.8\end{array}$ & $\begin{array}{l}73.8 \\
-6.1\end{array}$ & $\begin{array}{l}9.8 \\
1.7\end{array}$ & $\begin{array}{r}8.3 \\
-0.6\end{array}$ & $\begin{array}{r}10.4 \\
1.9\end{array}$ & $\begin{array}{l}78.1 \\
-1.9\end{array}$ & $\begin{array}{l}3.1 \\
0.6\end{array}$ \\
\hline & & \multicolumn{4}{|c|}{ Non working households } & \multicolumn{4}{|c|}{ Working households } & \multirow{2}{*}{\multicolumn{4}{|c|}{ Total households }} \\
\hline & \multirow[t]{2}{*}{ Total } & \multicolumn{2}{|c|}{ With children } & \multicolumn{2}{|c|}{ No children } & \multicolumn{2}{|c|}{ With children } & \multicolumn{2}{|c|}{ No children } & & & & \\
\hline & & Single adult & $\begin{array}{c}\text { Two adults } \\
\text { or more }\end{array}$ & Single adult & $\begin{array}{l}\text { Two adults } \\
\text { or more }\end{array}$ & Single adult & $\begin{array}{l}\text { Two adults } \\
\text { or more }\end{array}$ & Single adult & $\begin{array}{l}\text { Two adults } \\
\text { or more }\end{array}$ & With $\mathrm{cl}$ & children & \multicolumn{2}{|c|}{ No children } \\
\hline $\begin{array}{l}\text { Canada, } 1991 \\
\quad \text { Changes, } 1975-1991\end{array}$ & 100 & $\begin{array}{l}1.9 \\
1.1\end{array}$ & $\begin{array}{l}2.6 \\
1.9\end{array}$ & $\begin{array}{r}5.1 \\
-0.5\end{array}$ & $\begin{array}{l}7.9 \\
1.4\end{array}$ & $\begin{array}{l}2.4 \\
1.3\end{array}$ & $\begin{array}{r}46.1 \\
-0.4\end{array}$ & $\begin{array}{r}5.8 \\
-4.8\end{array}$ & $\begin{array}{r}28.0 \\
0.1\end{array}$ & & $\begin{array}{l}3.0 \\
3.9\end{array}$ & & $\begin{array}{l}6.8 \\
3.8\end{array}$ \\
\hline $\begin{array}{l}\text { France, } 1989 \\
\quad \text { Changes, 1984-1989 }\end{array}$ & 100 & $\begin{array}{l}1.2 \\
0.5\end{array}$ & $\begin{array}{r}6.6 \\
-1.2\end{array}$ & $\begin{array}{l}6.9 \\
1.1\end{array}$ & $\begin{array}{r}14.5 \\
-3.2\end{array}$ & $\begin{array}{l}1.9 \\
0.4\end{array}$ & $\begin{array}{r}44.9 \\
0.4\end{array}$ & $\begin{array}{l}3.5 \\
0.3\end{array}$ & $\begin{array}{r}20.4 \\
1.8\end{array}$ & & $\begin{array}{l}4.6 \\
0.1\end{array}$ & & $\begin{array}{l}5.3 \\
0.0\end{array}$ \\
\hline $\begin{array}{l}\text { Germany, } 1989 \\
\quad \text { Changes, 1978-1989 }\end{array}$ & 100 & $\begin{array}{l}1.0 \\
0.2\end{array}$ & $\begin{array}{r}1.3 \\
-4.7\end{array}$ & $\begin{array}{r}10.2 \\
1.8\end{array}$ & $\begin{array}{r}12.5 \\
-0.9\end{array}$ & $\begin{array}{l}1.5 \\
0.3\end{array}$ & $\begin{array}{r}37.0 \\
-13.4\end{array}$ & $\begin{array}{l}7.6 \\
4.4\end{array}$ & $\begin{array}{l}28.7 \\
12.1\end{array}$ & $\begin{array}{r}40 \\
-17\end{array}$ & $\begin{array}{l}0.8 \\
7.6\end{array}$ & & $\begin{array}{l}9.0 \\
7.4\end{array}$ \\
\hline $\begin{array}{l}\text { Sweden, } 1992 \\
\quad \text { Changes, 1975-1992 }\end{array}$ & 100 & $\begin{array}{l}1.2 \\
0.3\end{array}$ & $\begin{array}{r}1.3 \\
-0.4\end{array}$ & $\begin{array}{r}12.3 \\
1.7\end{array}$ & $\begin{array}{r}9.7 \\
-0.3\end{array}$ & $\begin{array}{l}5.5 \\
1.4\end{array}$ & $\begin{array}{r}36.7 \\
-6.0\end{array}$ & $\begin{array}{r}15.4 \\
2.3\end{array}$ & $\begin{array}{r}17.7 \\
0.6\end{array}$ & & $\begin{array}{l}4.7 \\
4.7\end{array}$ & & $\begin{array}{l}5.1 \\
4.3\end{array}$ \\
\hline $\begin{array}{l}\text { United States, } 1994 \\
\quad \text { Changes, 1974-1994 }\end{array}$ & 100 & $\begin{array}{l}2.2 \\
0.1\end{array}$ & $\begin{array}{r}3.1 \\
-1.2\end{array}$ & $\begin{array}{l}4.9 \\
1.2\end{array}$ & $\begin{array}{l}8.5 \\
1.2\end{array}$ & $\begin{array}{l}4.6 \\
1.5\end{array}$ & $\begin{array}{r}47.6 \\
-7.7\end{array}$ & $\begin{array}{l}4.6 \\
1.6\end{array}$ & $\begin{array}{r}24.4 \\
3.3\end{array}$ & & $\begin{array}{l}7.5 \\
7.3\end{array}$ & & $\begin{array}{l}2.4 \\
7.3\end{array}$ \\
\hline
\end{tabular}

Source: Luxembourg Income Study. 
Table 5.7. Poverty rates ${ }^{1}$ after taxes and transfers

Equivalence scale elasticity $=0.5$

Per cent of poor ${ }^{2}$ individuals in each group, and changes in percentage points

\begin{tabular}{|c|c|c|c|c|c|c|c|c|c|c|c|c|c|}
\hline & \multirow{3}{*}{ Total } & \multicolumn{4}{|c|}{ By age of the household's head } & \multicolumn{4}{|c|}{ By family type } & \multicolumn{4}{|c|}{ By work attachment } \\
\hline & & \multirow{2}{*}{ Head below 30} & \multirow{2}{*}{$\begin{array}{l}\text { Head between } \\
30 \text { and } 50\end{array}$} & \multirow{2}{*}{$\begin{array}{l}\text { Head between } \\
50 \text { and } 65\end{array}$} & \multirow{2}{*}{ Head above 65} & \multicolumn{2}{|c|}{ Single-adult households } & \multicolumn{2}{|c|}{\begin{tabular}{|l} 
Two-adult households \\
\end{tabular}} & \multicolumn{2}{|c|}{ Non-working households } & \multicolumn{2}{|c|}{ Working households } \\
\hline & & & & & & Head below 65 & Head above 65 & Head below 65 & Head above 65 & Head below 65 & Head above 65 & Head below 65 & Head above 65 \\
\hline \multirow{2}{*}{$\begin{array}{l}\text { Canada, } 1991 \\
\quad \text { Changes, 1975-1991 }\end{array}$} & 11.2 & 20.9 & 9.7 & 10.7 & 5.1 & 38.4 & 11.8 & 7.8 & 2.6 & 55.8 & 6.6 & 7.1 & 0.3 \\
\hline & -3.9 & 8.0 & 0.1 & -3.4 & -30.1 & 7.2 & -51.3 & -0.3 & -19.4 & -17.8 & -41.1 & -1.2 & -9.6 \\
\hline \multirow{2}{*}{$\begin{array}{l}\text { France, } 1989 \\
\quad \text { Changes, } 1984-1989\end{array}$} & 8.2 & 8.9 & 6.4 & 9.3 & 12.4 & 17.7 & 22.2 & 6.2 & 8.1 & 29.3 & 13.9 & 2.3 & 1.8 \\
\hline & -2.1 & 0.4 & -1.1 & -3.6 & -7.0 & 1.2 & -1.6 & -2.1 & -9.4 & -3.0 & -5.8 & 0.0 & -3.8 \\
\hline \multirow{2}{*}{$\begin{array}{l}\text { Germany, } 1989 \\
\quad \text { Changes, 1978-1989 }\end{array}$} & 5.5 & 9.8 & 3.8 & 5.1 & 7.6 & 18.8 & 12.2 & 2.4 & 4.6 & 27.2 & 8.7 & 2.6 & 0.0 \\
\hline & -1.0 & 1.3 & 1.5 & -0.3 & -10.3 & -1.2 & -19.2 & -0.5 & -6.3 & 10.6 & -11.3 & 0.2 & -0.9 \\
\hline \multirow{2}{*}{$\begin{array}{l}\text { Sweden, } 1992 \\
\quad \text { Changes, } 1975-1992\end{array}$} & 6.5 & 18.1 & 2.8 & 2.8 & 6.3 & 16.0 & 13.3 & 2.0 & 0.6 & 31.8 & 6.8 & 3.3 & 0.2 \\
\hline & 0.1 & 8.4 & 0.1 & -2.0 & -7.1 & 2.9 & -10.9 & -0.1 & -5.0 & 1.0 & -7.3 & 1.0 & -3.3 \\
\hline \multirow{5}{*}{$\begin{array}{l}\text { United States, } 1994 \\
\quad \text { Changes, 1974-1994 } \\
\end{array}$} & 17.7 & 29.7 & 15.2 & 12.4 & 20.5 & 40.7 & 38.0 & 13.2 & 13.9 & 60.4 & 24.2 & 12.6 & 8.1 \\
\hline & 2.4 & 10.6 & 3.6 & 0.0 & -8.5 & -6.2 & -14.3 & 3.4 & -6.8 & 10.1 & -10.4 & 3.2 & -1.9 \\
\hline & \multirow{3}{*}{ Total } & \multicolumn{4}{|c|}{ Non working households } & \multicolumn{4}{|c|}{ Working households } & \multirow{2}{*}{\multicolumn{4}{|c|}{ Total households }} \\
\hline & & \multicolumn{2}{|c|}{\begin{tabular}{|c|} 
With children \\
\end{tabular}} & \multicolumn{2}{|c|}{ No children } & \multicolumn{2}{|c|}{ With children } & \multicolumn{2}{|c|}{ No children } & & & & \\
\hline & & Single adult & $\begin{array}{l}\text { Two adults } \\
\text { or more } \\
\end{array}$ & Single adult & $\begin{array}{c}\text { Two adults } \\
\text { or more }\end{array}$ & Single adult & $\begin{array}{c}\text { Two adults } \\
\text { or more }\end{array}$ & Single adult & $\begin{array}{l}\text { Two adults } \\
\text { or more }\end{array}$ & With c & children & No ch & nildren \\
\hline Canada, 1991 & 11.2 & 84.1 & 50.5 & 31.3 & 12.4 & 36.8 & 6.4 & 16.1 & 3.2 & & 2.7 & & 9.4 \\
\hline Changes, 1975-1991 & -3.9 & 3.2 & -37.2 & -41.3 & -22.1 & 0.9 & -1.4 & -2.5 & -1.8 & & 1.9 & & 9.7 \\
\hline France, 1989 & 8.2 & 61.0 & 33.8 & 23.7 & 13.8 & 8.7 & 2.1 & 1.5 & 2.1 & & 7.5 & & 9.1 \\
\hline Changes, 1984-1989 & -2.1 & 3.4 & -8.4 & -3.1 & -6.3 & 3.3 & 0.0 & -0.9 & 0.2 & & 1.2 & & 3.2 \\
\hline Germany, 1989 & 5.5 & 57.0 & 26.6 & 17.5 & 8.3 & 12.6 & 1.5 & 10.2 & 0.9 & & 4.0 & & 6.6 \\
\hline Changes, 1978-1989 & -1.0 & 7.4 & 18.2 & -15.2 & -4.4 & -1.8 & 0.3 & 5.2 & -0.6 & & 1.2 & & 5.1 \\
\hline Sweden, 1992 & 6.5 & 11.4 & 26.5 & 24.7 & 1.7 & 3.5 & 1.4 & 12.5 & 0.9 & & 2.7 & & 9.6 \\
\hline Changes, 1975-1992 & 0.1 & -1.3 & 1.7 & -6.5 & -5.8 & 1.7 & 0.2 & 4.7 & -0.3 & & 0.4 & & 0.8 \\
\hline United States, 1994 & 17.7 & 89.3 & 60.8 & 41.3 & 19.5 & 41.8 & 12.7 & 13.5 & 6.2 & & 0.5 & & 3.7 \\
\hline Changes, 1974-1994 & 2.4 & 0.9 & 21.0 & -11.4 & -6.6 & -6.6 & 4.0 & -0.7 & 1.3 & & 5.3 & & 1.4 \\
\hline
\end{tabular}

1. Poverty rate by group is the number of "poor" individuals in a group as a per cent of the total number of individuals in that group.

2. "Poor" are individuals with adjusted equivalent income below 50 per cent of median adjusted equivalent disposable income.

Source: Luxembourg Income Study. 


\section{Table 5.8. Structure of poverty ${ }^{1}$ after taxes and transfers}

Equivalence scale elasticity $=0.5$

Per cent of all poor ${ }^{2}$ individuals belonging to each group, and changes in percentage points

\begin{tabular}{|c|c|c|c|c|c|c|c|c|c|c|c|c|c|}
\hline & \multirow{3}{*}{ Total } & \multicolumn{4}{|c|}{ By age of the household's head } & \multicolumn{4}{|c|}{ By family type } & \multicolumn{4}{|c|}{ By work attachment } \\
\hline & & \multirow[t]{2}{*}{ Head below 30} & \multirow{2}{*}{$\begin{array}{l}\text { Head between } \\
30 \text { and } 50\end{array}$} & \multirow{2}{*}{$\begin{array}{l}\text { Head between } \\
50 \text { and } 65\end{array}$} & \multirow{2}{*}{ Head above 65} & \multicolumn{2}{|c|}{ Single-adult households } & \multicolumn{2}{|c|}{ Two-adult households ${ }^{2}$} & \multicolumn{2}{|c|}{ Non-working households } & \multicolumn{2}{|c|}{ Working households } \\
\hline & & & & & & Head below 65 & Head above 65 & Head below 65 & Head above 65 & Head below 65 & Head above 65 & Head below 65 & Head above 65 \\
\hline $\begin{array}{l}\text { Canada, } 1991 \\
\quad \text { Changes, } 1975-1991\end{array}$ & 100 & $\begin{array}{r}30.0 \\
9.1\end{array}$ & $\begin{array}{l}46.3 \\
21.1\end{array}$ & $\begin{array}{r}18.5 \\
-2.5\end{array}$ & $\begin{array}{r}5.2 \\
-27.7\end{array}$ & $\begin{array}{l}41.7 \\
13.4\end{array}$ & $\begin{array}{r}3.3 \\
-15.7\end{array}$ & $\begin{array}{l}53.1 \\
14.3\end{array}$ & $\begin{array}{r}1.9 \\
-12.0\end{array}$ & $\begin{array}{l}44.1 \\
23.4\end{array}$ & $\begin{array}{r}5.1 \\
-24.8\end{array}$ & $\begin{array}{r}50.7 \\
4.3\end{array}$ & $\begin{array}{r}0.1 \\
-3.0\end{array}$ \\
\hline $\begin{array}{l}\text { France, } 1989 \\
\quad \text { Changes, 1984-1989 }\end{array}$ & 100 & $\begin{array}{r}14.5 \\
1.4\end{array}$ & $\begin{array}{r}39.5 \\
3.9\end{array}$ & $\begin{array}{r}24.3 \\
-3.8\end{array}$ & $\begin{array}{r}21.7 \\
-1.4\end{array}$ & $\begin{array}{r}19.6 \\
7.6\end{array}$ & $\begin{array}{r}11.9 \\
3.3\end{array}$ & $\begin{array}{l}58.7 \\
-6.2\end{array}$ & $\begin{array}{r}9.8 \\
-4.7\end{array}$ & $\begin{array}{l}59.2 \\
-3.6\end{array}$ & $\begin{array}{r}21.3 \\
-1.7\end{array}$ & $\begin{array}{r}19.2 \\
5.0\end{array}$ & $\begin{array}{l}0.4 \\
0.3\end{array}$ \\
\hline $\begin{array}{l}\text { Germany, } 1989 \\
\quad \text { Changes, 1978-1989 }\end{array}$ & 100 & $\begin{array}{l}19.7 \\
11.0\end{array}$ & $\begin{array}{l}29.9 \\
12.9\end{array}$ & $\begin{array}{r}24.0 \\
3.1\end{array}$ & $\begin{array}{r}26.3 \\
-27.0\end{array}$ & $\begin{array}{l}43.6 \\
22.2\end{array}$ & $\begin{array}{r}16.6 \\
-15.3\end{array}$ & $\begin{array}{r}30.0 \\
4.8\end{array}$ & $\begin{array}{r}9.7 \\
-11.7\end{array}$ & $\begin{array}{l}41.4 \\
12.4\end{array}$ & $\begin{array}{r}26.3 \\
-26.7\end{array}$ & $\begin{array}{l}32.2 \\
14.6\end{array}$ & $\begin{array}{r}0.0 \\
-0.3\end{array}$ \\
\hline $\begin{array}{l}\text { Sweden, } 1992 \\
\quad \text { Changes, 1975-1992 }\end{array}$ & 100 & $\begin{array}{l}55.8 \\
22.7\end{array}$ & $\begin{array}{r}20.1 \\
2.4\end{array}$ & $\begin{array}{r}7.0 \\
-8.3\end{array}$ & $\begin{array}{r}17.1 \\
-16.7\end{array}$ & $\begin{array}{l}65.3 \\
20.5\end{array}$ & $\begin{array}{r}16.2 \\
-9.5\end{array}$ & $\begin{array}{l}17.5 \\
-3.8\end{array}$ & $\begin{array}{r}1.0 \\
-7.3\end{array}$ & $\begin{array}{r}39.7 \\
1.3\end{array}$ & $\begin{array}{r}17.1 \\
-16.2\end{array}$ & $\begin{array}{l}43.1 \\
15.4\end{array}$ & $\begin{array}{r}0.0 \\
-0.5\end{array}$ \\
\hline \multirow[t]{4}{*}{ Changes, 1974-1994 } & 100 & $\begin{array}{r}26.3 \\
0.4 \\
\end{array}$ & $\begin{array}{r}45.2 \\
9.9 \\
\end{array}$ & $\begin{array}{l}12.8 \\
-5.0 \\
\end{array}$ & $\begin{array}{l}15.7 \\
-5.3 \\
\end{array}$ & $\begin{array}{r}29.1 \\
1.4 \\
\end{array}$ & $\begin{array}{r}8.0 \\
-2.0 \\
\end{array}$ & $\begin{array}{r}55.2 \\
3.9 \\
\end{array}$ & $\begin{array}{r}7.7 \\
-3.3 \\
\end{array}$ & $\begin{array}{r}28.5 \\
-1.0 \\
\end{array}$ & $\begin{array}{l}14.3 \\
-5.1 \\
\end{array}$ & $\begin{array}{r}55.8 \\
6.3 \\
\end{array}$ & $\begin{array}{r}1.4 \\
-0.2 \\
\end{array}$ \\
\hline & & \multicolumn{4}{|c|}{ Non working households } & \multicolumn{4}{|c|}{ Working households } & \multirow{2}{*}{\multicolumn{4}{|c|}{ Total households }} \\
\hline & \multirow[t]{2}{*}{ Total } & \multicolumn{2}{|c|}{ With children } & \multicolumn{2}{|c|}{ No children } & \multicolumn{2}{|c|}{ With children } & \multicolumn{2}{|c|}{ No children } & & & & \\
\hline & & Single adult & $\begin{array}{l}\text { Two adults } \\
\text { or more }\end{array}$ & Single adult & $\begin{array}{l}\text { Two adults } \\
\text { or more }\end{array}$ & Single adult & $\begin{array}{l}\text { Two adults } \\
\text { or more }\end{array}$ & Single adult & $\begin{array}{l}\text { Two adults } \\
\text { or more }\end{array}$ & With $\mathrm{c}$ & hildren & \multicolumn{2}{|c|}{ No children } \\
\hline $\begin{array}{l}\text { Canada, } 1991 \\
\quad \text { Changes, } 1975-1991\end{array}$ & 100 & $\begin{array}{l}14.3 \\
10.0\end{array}$ & $\begin{array}{r}11.8 \\
7.7\end{array}$ & $\begin{array}{r}14.3 \\
-12.8\end{array}$ & $\begin{array}{r}8.8 \\
-6.2\end{array}$ & $\begin{array}{l}7.9 \\
5.3\end{array}$ & $\begin{array}{r}26.3 \\
2.1\end{array}$ & $\begin{array}{r}8.4 \\
-4.8\end{array}$ & $\begin{array}{r}8.2 \\
-1.3\end{array}$ & $\begin{array}{l}60 \\
25\end{array}$ & .4 & & $\begin{array}{l}9.6 \\
5.1\end{array}$ \\
\hline $\begin{array}{l}\text { France, } 1989 \\
\quad \text { Changes, 1984-1989 }\end{array}$ & 100 & $\begin{array}{l}8.9 \\
5.0\end{array}$ & $\begin{array}{r}27.2 \\
-4.9\end{array}$ & $\begin{array}{r}19.9 \\
4.8\end{array}$ & $\begin{array}{r}24.4 \\
-10.2\end{array}$ & $\begin{array}{l}2.0 \\
1.2\end{array}$ & $\begin{array}{r}11.6 \\
2.4\end{array}$ & $\begin{array}{r}0.6 \\
-0.1\end{array}$ & $\begin{array}{l}5.3 \\
1.7\end{array}$ & $\begin{array}{r}49 \\
3\end{array}$ & .7 & & $\begin{array}{l}0.3 \\
3.8\end{array}$ \\
\hline $\begin{array}{l}\text { Germany, } 1989 \\
\quad \text { Changes, 1978-1989 }\end{array}$ & 100 & $\begin{array}{r}10.3 \\
4.2\end{array}$ & $\begin{array}{r}6.3 \\
-1.5\end{array}$ & $\begin{array}{r}32.3 \\
-9.8\end{array}$ & $\begin{array}{l}18.8 \\
-7.2\end{array}$ & $\begin{array}{l}3.4 \\
0.8\end{array}$ & $\begin{array}{l}9.8 \\
0.9\end{array}$ & $\begin{array}{l}14.1 \\
11.6\end{array}$ & $\begin{array}{l}4.9 \\
1.0\end{array}$ & $\begin{array}{r}29 \\
4\end{array}$ & .8 & & $\begin{array}{l}0.2 \\
4.4\end{array}$ \\
\hline $\begin{array}{l}\text { Sweden, } 1992 \\
\quad \text { Changes, 1975-1992 }\end{array}$ & 100 & $\begin{array}{l}2.1 \\
0.3\end{array}$ & $\begin{array}{r}5.3 \\
-1.3\end{array}$ & $\begin{array}{r}46.9 \\
-4.8\end{array}$ & $\begin{array}{r}2.5 \\
-9.2\end{array}$ & $\begin{array}{l}2.9 \\
1.8\end{array}$ & $\begin{array}{l}8.1 \\
0.2\end{array}$ & $\begin{array}{l}29.6 \\
13.7\end{array}$ & $\begin{array}{r}2.5 \\
-0.8\end{array}$ & $\begin{array}{r}18 \\
1\end{array}$ & .5 & & $\begin{array}{l}1.5 \\
1.1\end{array}$ \\
\hline $\begin{array}{l}\text { United States, } 1994 \\
\quad \text { Changes, 1974-1994 }\end{array}$ & 100 & $\begin{array}{l}11.1 \\
-1.1 \\
\end{array}$ & $\begin{array}{l}10.7 \\
-0.5 \\
\end{array}$ & $\begin{array}{l}11.5 \\
-1.3 \\
\end{array}$ & $\begin{array}{r}9.4 \\
-3.1 \\
\end{array}$ & $\begin{array}{r}10.9 \\
1.1 \\
\end{array}$ & $\begin{array}{r}34.3 \\
2.5 \\
\end{array}$ & $\begin{array}{l}3.5 \\
0.7\end{array}$ & $\begin{array}{l}8.6 \\
1.8 \\
\end{array}$ & $\begin{array}{r}67 \\
2 \\
\end{array}$ & 80 & & $\begin{array}{l}3.0 \\
2.0\end{array}$ \\
\hline
\end{tabular}

1. The structure of poverty is the number of "poor" individuals in each group as a per cent of all "poor" individuals.

2. "Poor" are individuals with adjusted equivalent income below 50 per cent of median adjusted equivalent disposable income.

Source: Luxembourg Income Study. 
$\mathrm{ECO} / \mathrm{WKP}(98) 2$

Table 5.9. Reduction of poverty due to taxes and transfers

\begin{tabular}{|c|c|c|c|c|c|c|c|}
\hline & & \multicolumn{3}{|c|}{ Poverty rates (per cent) } & \multicolumn{2}{|c|}{ Transfers per capita } & \multirow{2}{*}{$\begin{array}{l}\text { Number of poor } \\
\text { escaping poverty } \\
\text { per hundreds of } \\
\text { US } \$ \text { of transfers }\end{array}$} \\
\hline & & $\begin{array}{c}\text { Before taxes and } \\
\text { transfers }(1)\end{array}$ & $\begin{array}{l}\text { After taxes and } \\
\text { transfers (2) }\end{array}$ & $\begin{array}{l}\text { Rate of poverty } \\
\text { reduction }(1) /(2)-1\end{array}$ & $\begin{array}{l}\text { In real national } \\
\text { currencies }^{1}\end{array}$ & $\begin{array}{l}\text { In constant prices } \\
\text { and constant } \\
\text { PPPs (US } \$ \text { ) }\end{array}$ & \\
\hline \multirow[t]{3}{*}{ Canada } & 1975 & 22.6 & 15.0 & -33.6 & 853 & 701 & 11 \\
\hline & 1991 & 22.9 & 11.2 & -51.2 & 1367 & 1123 & 10 \\
\hline & $\%$ changes $1975-91$ & 1.1 & -25.7 & 52.4 & 60.2 & 60.2 & -3.7 \\
\hline \multirow[t]{3}{*}{ Sweden } & 1975 & 25.9 & 6.4 & -75.3 & 25332 & 4126 & 5 \\
\hline & 1992 & 33.9 & 6.5 & -80.8 & 48814 & 7951 & 3 \\
\hline & $\%$ changes $1975-92$ & 30.6 & 1.5 & 7.3 & 92.7 & 92.7 & -27.5 \\
\hline \multirow[t]{3}{*}{ United States } & 1974 & 20.8 & 15.2 & -26.8 & 558 & 558 & 10 \\
\hline & 1995 & 25.3 & 17.7 & -30.2 & 819 & 819 & 9 \\
\hline & $\%$ changes $1974-95$ & 21.6 & 15.9 & 12.8 & 46.7 & 46.7 & -6.5 \\
\hline
\end{tabular}

1. Deflated with the CPI of the initial year.

Source: OECD. 
Figure 2.1. Equivalent disposable income: gains and losses by quintile

ECO/WKP(98)2

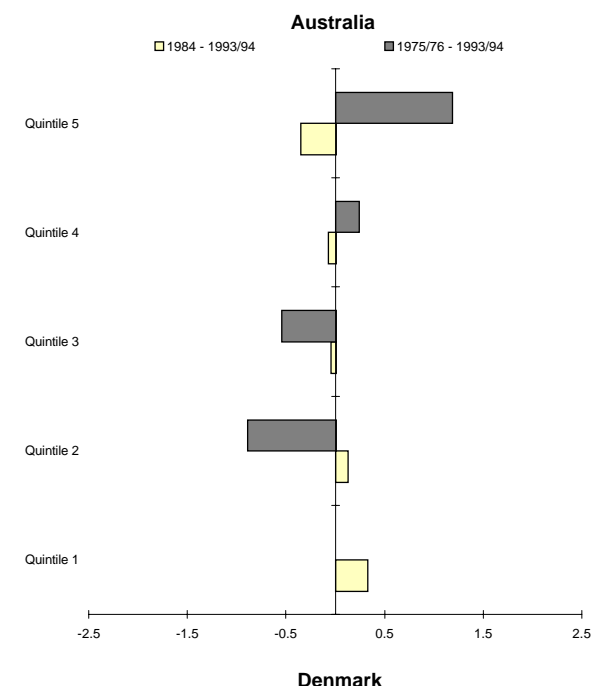

Equivalence scale $=0.5$

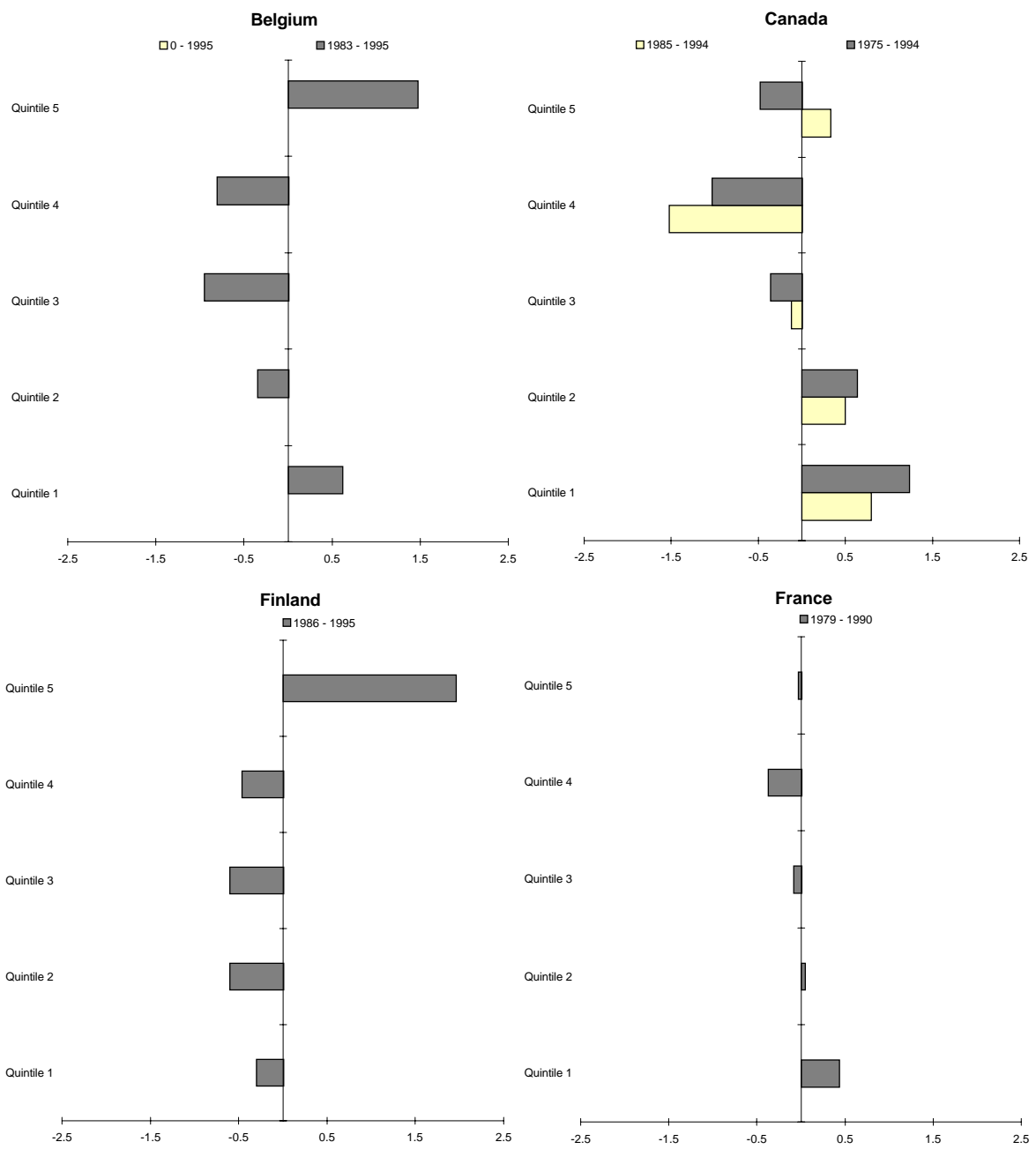


ECO/WKP(98)2

Figure 2.1 (cont.). Equivalent disposable income: gains and losses by quintile' Equivalence scale $=0.5$
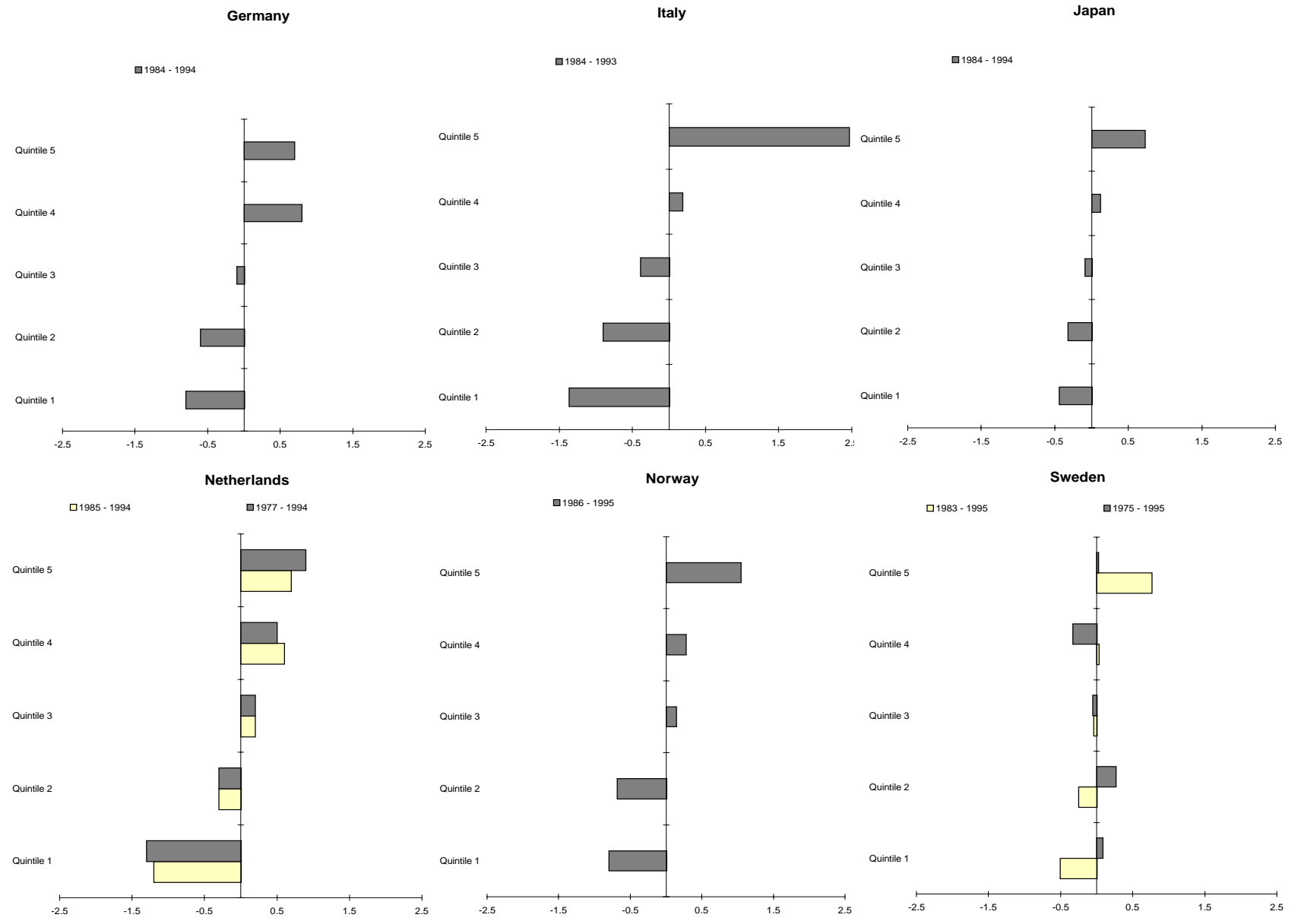
Figure 2.1 (cont.). Equivalent disposable income: gains and losses by quintile'

$$
\text { Equivalence scale }=0.5
$$

United States

口1985- 1995

-1974-1995

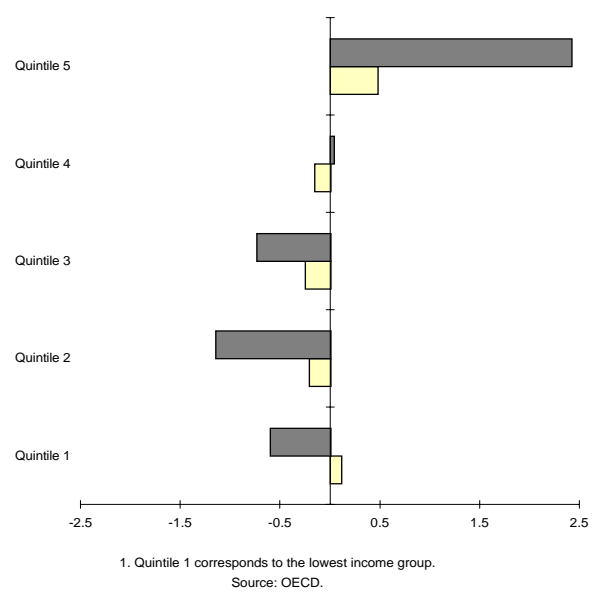




\section{ECO/WKP(98)2}

Figure 4.1 Contribution of income components to changes in relative disposable income, by work attachment of households Population belonging to households with a working age head Equivalence scale $=0.5$
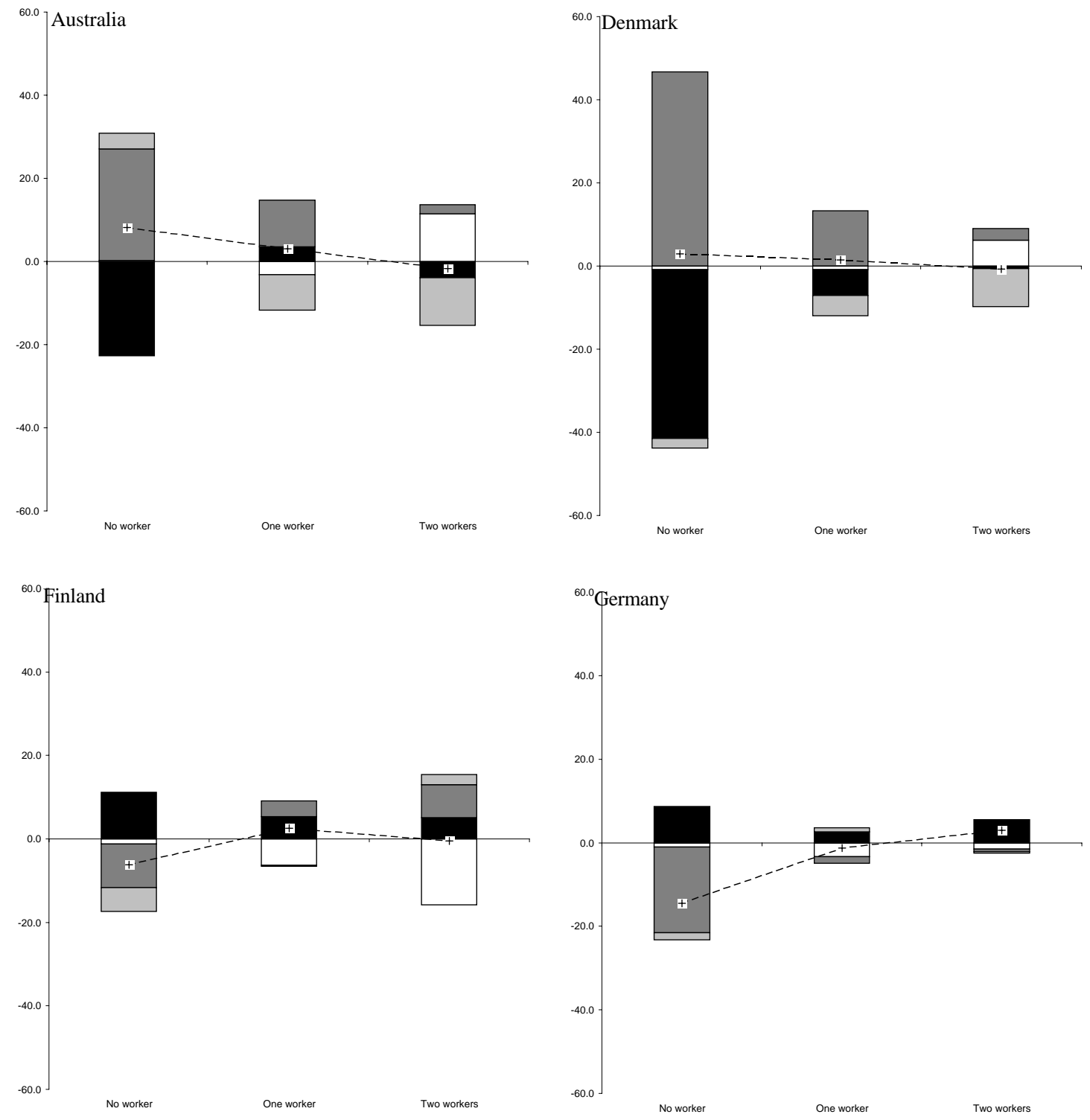
Figure 4.1 (cont.) Contribution of income components to changes in relative disposable income, by work attachment of households ${ }^{1}$ Population belonging to households with a working age head

$$
\text { Equivalence scale }=0.5
$$
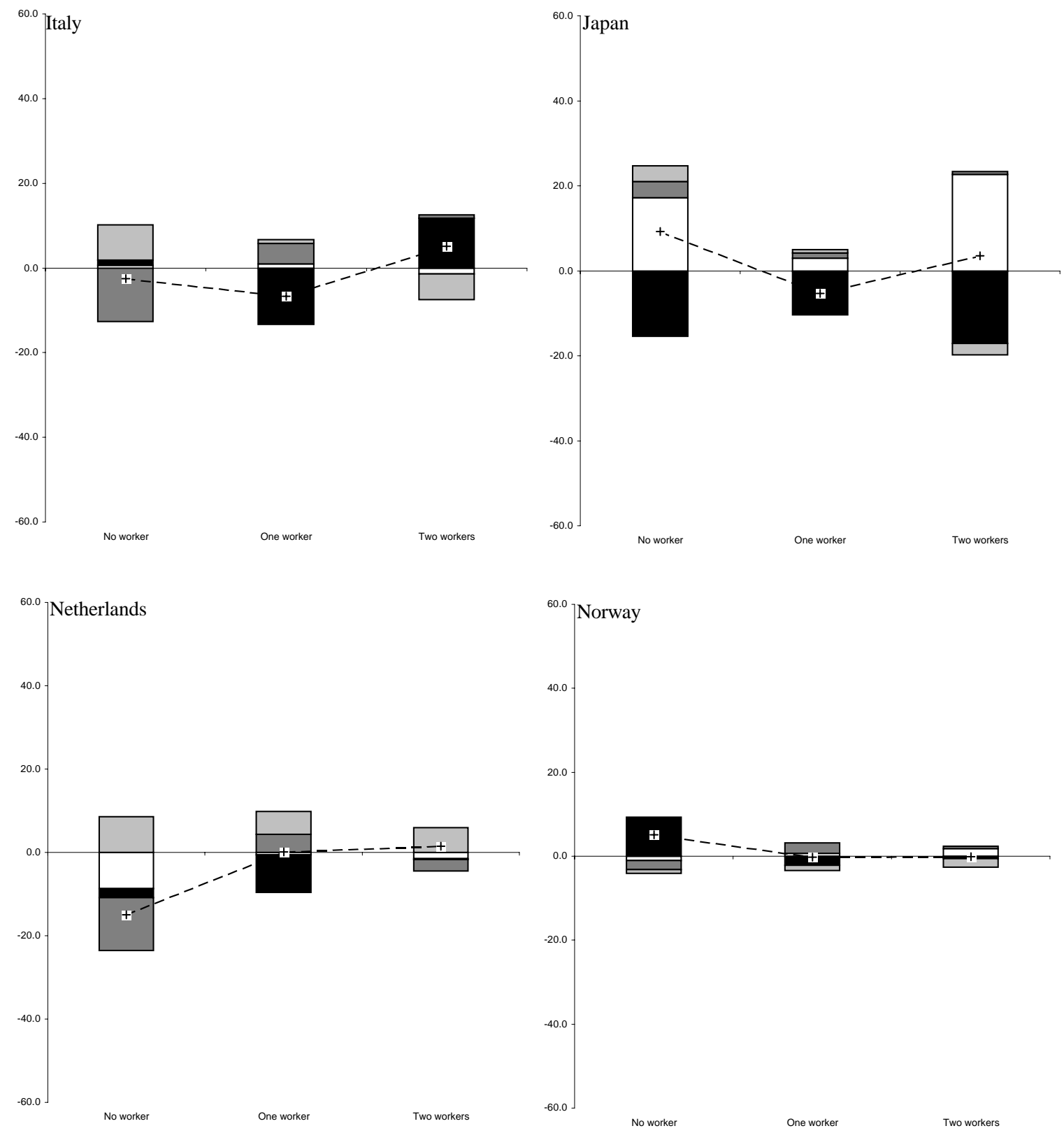


\section{$\mathrm{ECO} / \mathrm{WKP}(98) 2$}

Figure 4.1 (cont.) Contribution of income components to changes in relative disposable income, by work attachment of households ${ }^{1}$ Population belonging to households with a working age head

$$
\text { Equivalence scale }=0.5
$$
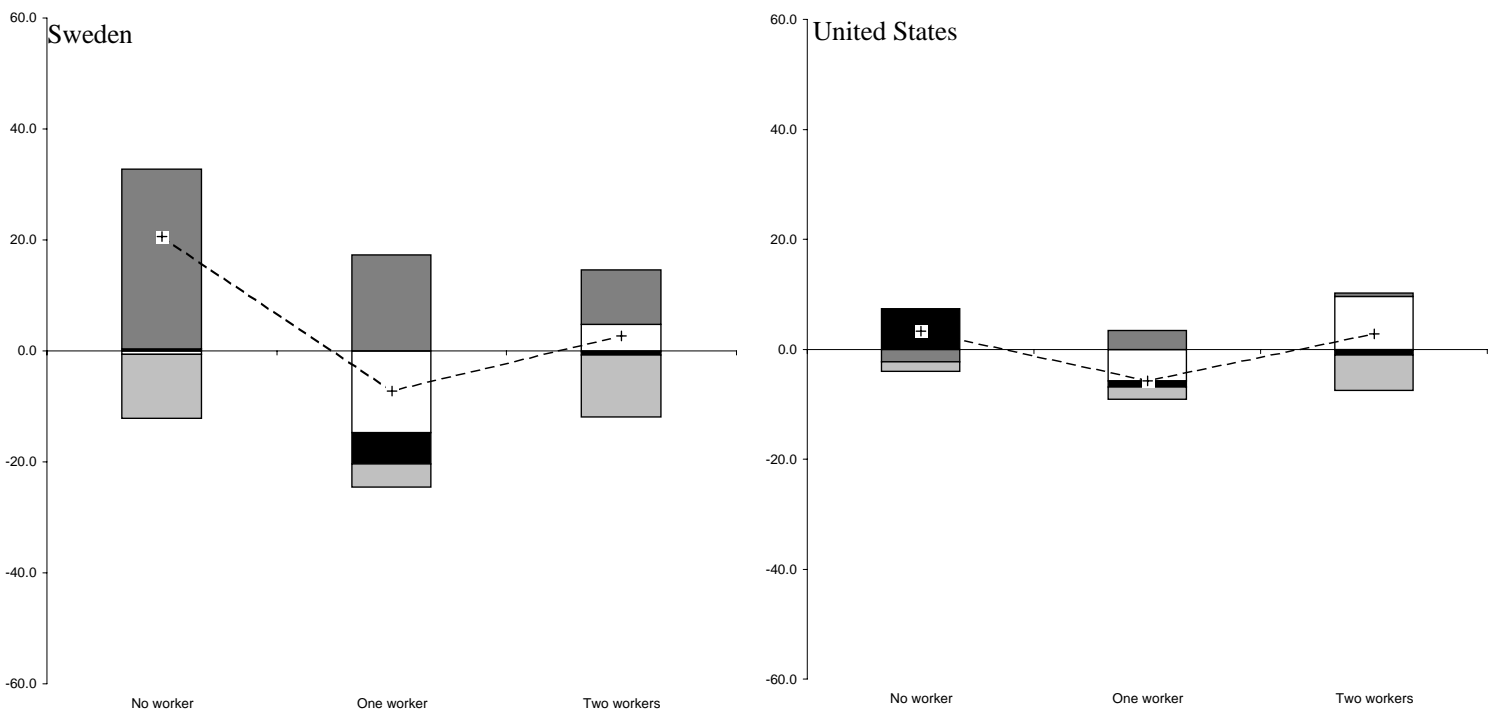

$\square$ EH+ES+EO K+SE $\square$ KR $\square-T A \quad-+-$ Group Mean Diposable Income in Real Terms

Source : OECD

1. The dotted line represents the growth rate of the relative income by household group (i.e., the ratio of the average disposable income of the specific group relative to the population mean). To calculate the contribution of each income sources by group, the following procedure was carried out : i) for a given group, the growth rate of each component of income was calculated; ii) this growth rate was then expressed as a ratio of the growth rate of the mean disposable income of the total population; and iii) the resulting relative growth rate was then weighted by the importance of each income component in the disposable income for the group considered. For each household group, the sum of the contribution is equal to the growth rate of the relative income (See Annex 2 ). 
ECO/WKP(98)2

Figure 4.2 Contribution of income components to the changes in relative disposable income, by age of household head ${ }^{1}$ Equivalence scale $=0.5$
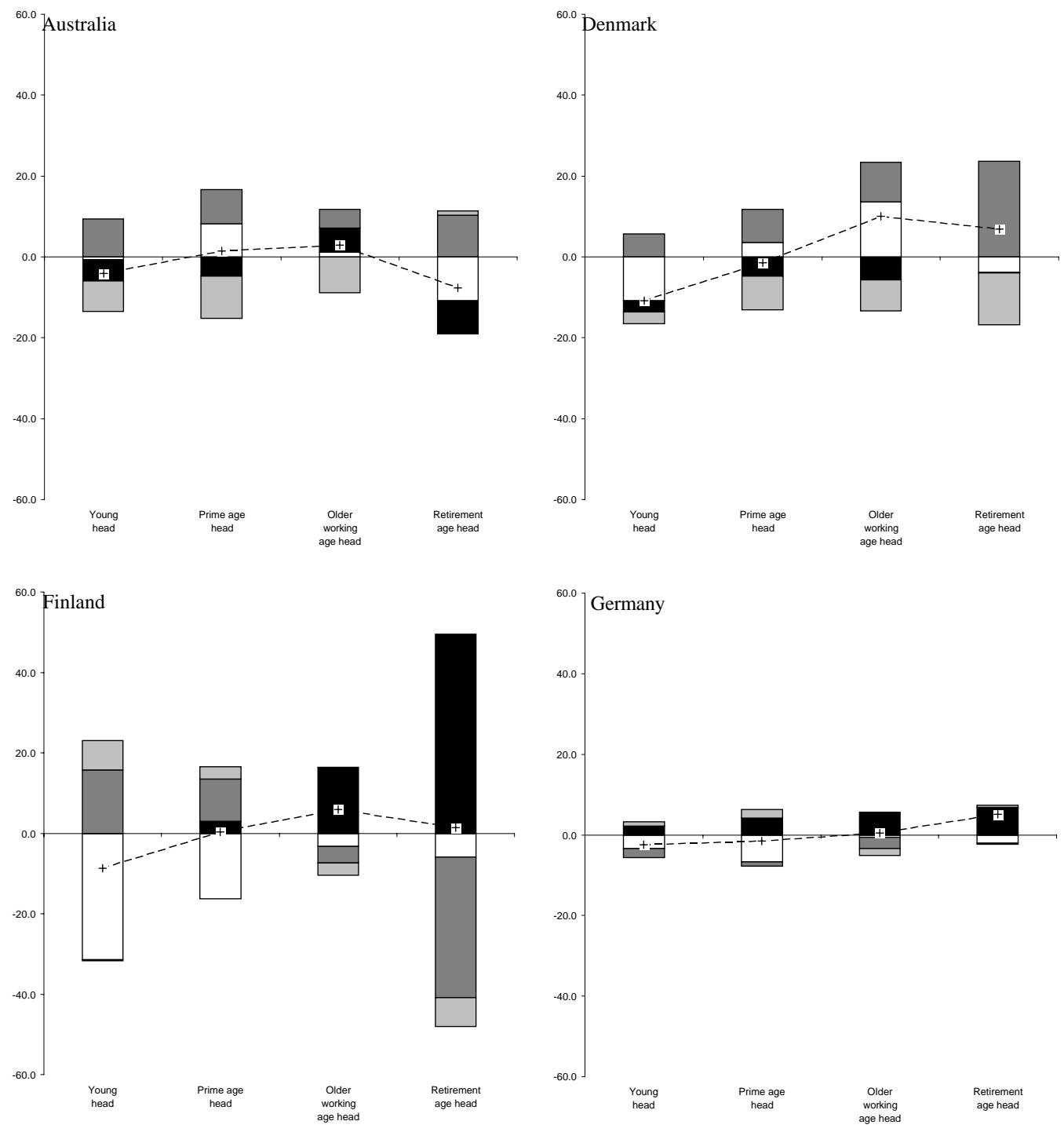


\section{$\mathrm{ECO} / \mathrm{WKP}(98) 2$}

Figure 4.2 (cont.) Contribution of income components to the changes in relative disposable income, by age of household head' Equivalence scale $=0.5$
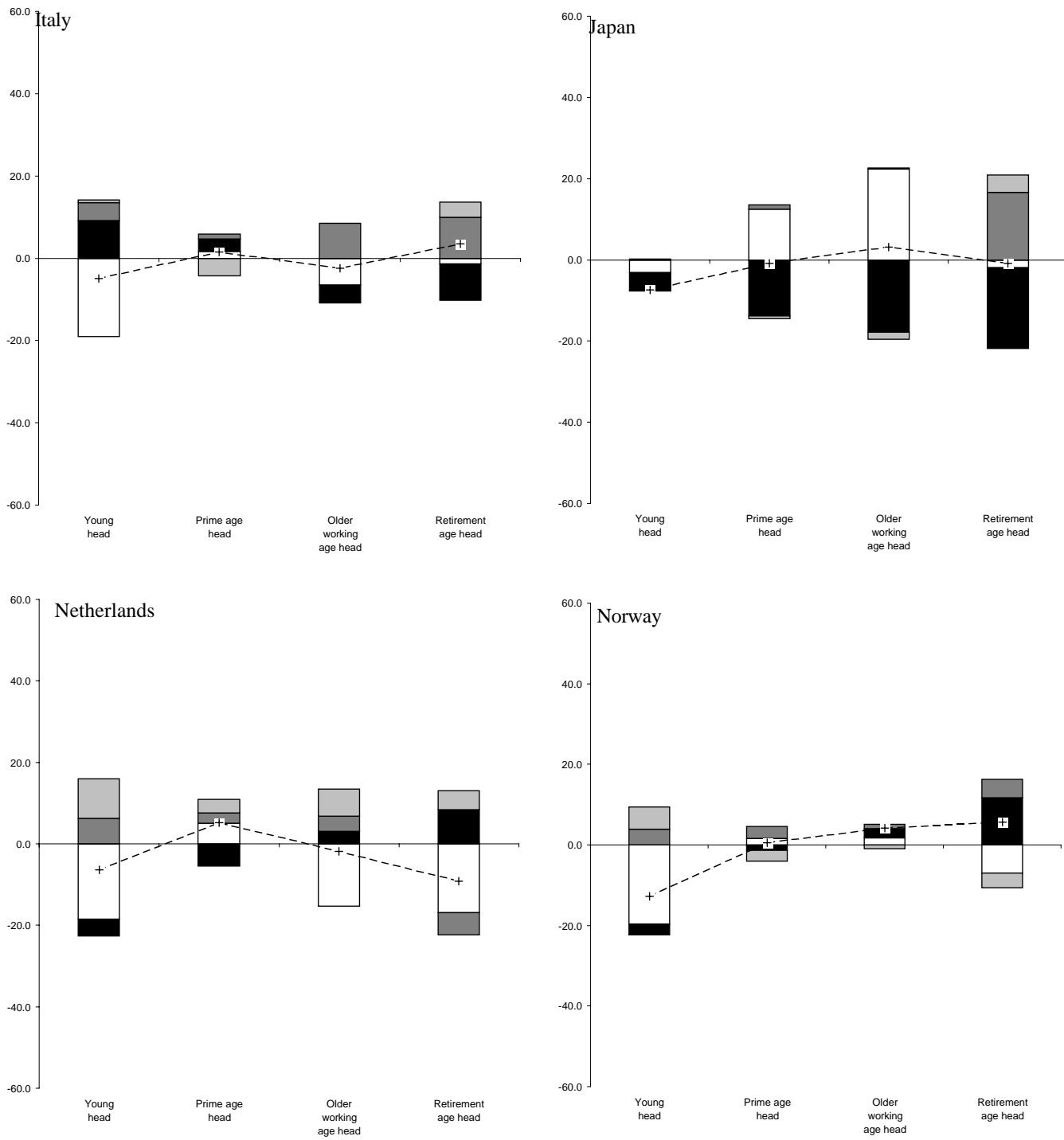
ECO/WKP(98)2

Figure 4.2 (cont.) Contribution of income components to the changes in relative disposable income, by age of household head ${ }^{1}$ Equivalence scale $=0.5$
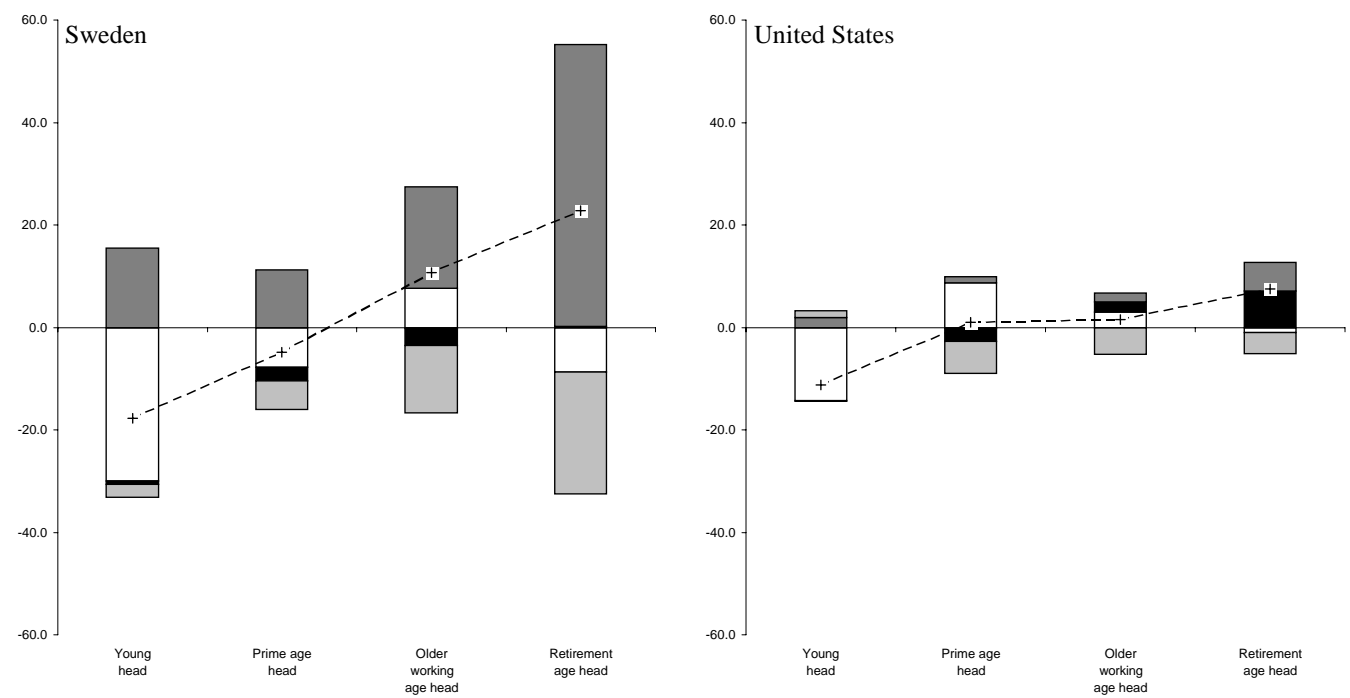

\footnotetext{
שEarnings 2 Capital and self-employment income $\quad$ Transfers $\Longleftarrow$ Taxes $\quad-+-$ - Group Mean Diposable Income in Real Terms Source : OECD.

1. The dotted line represents the growth rate of the relative income by household group (i.e., the ratio of the average disposable income of the specific group relative to the population mean). To calculate the contribution of each income sources by group, the following procedure was carried out: :i) for a given group, the grouth rate of each component of income was calculated;

ii) this growth rate was then expressed as a ratio of the growth rate of the mean disposable income of the total population; and iii) the resulting relative growth rate was then weighted by the importance

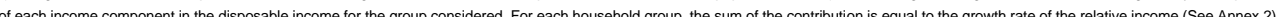


ECO/WKP(98)2

Figure 4.3 Contribution of income components to changes in relative disposable income, by family type ${ }^{1}$ Equivalence scale $=0.5$
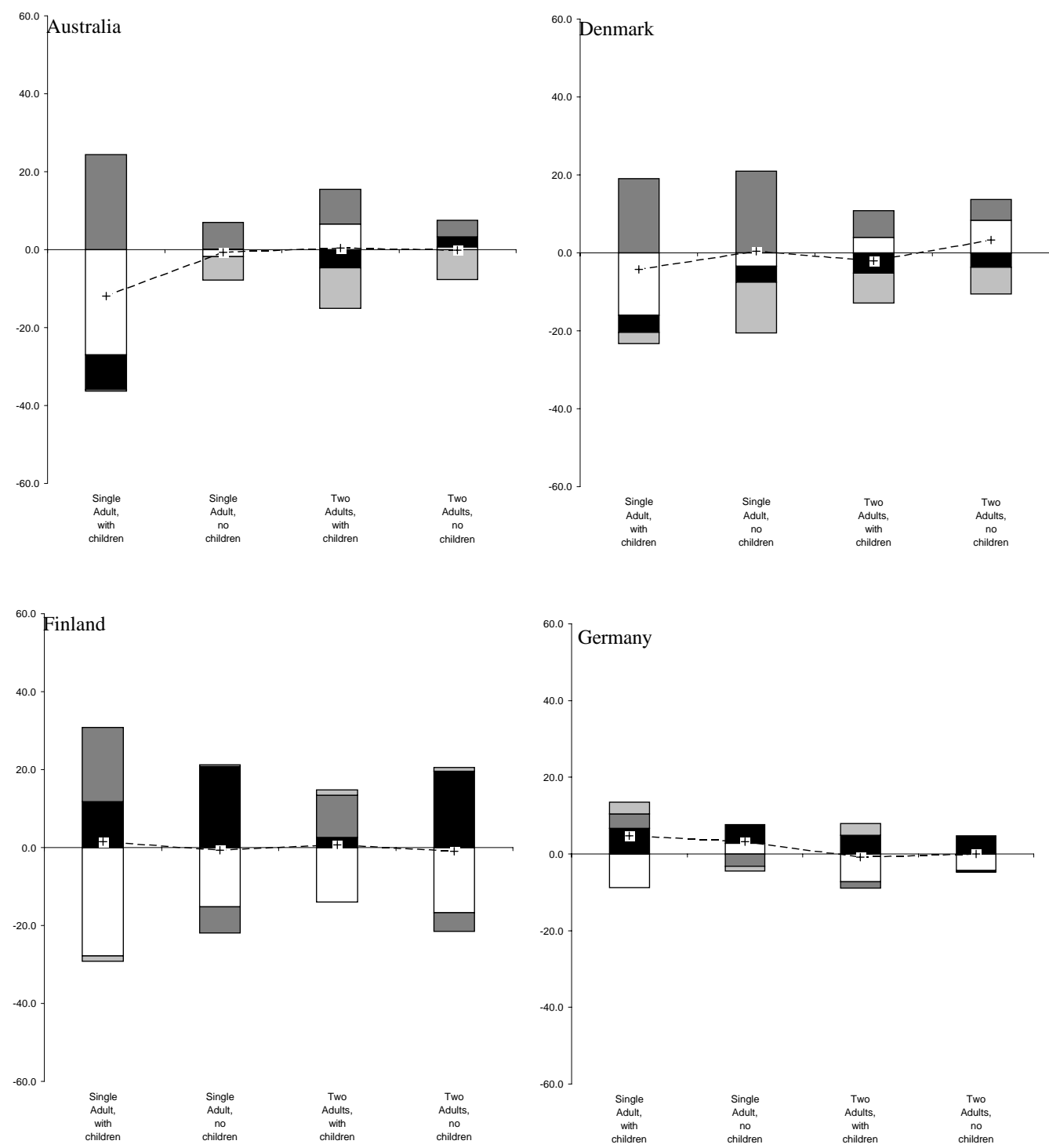
ECO/WKP(98)2

Figure 4.3 (cont.) Contribution of income components to changes in relative disposable income, by family type Equivalence scale $=0.5$
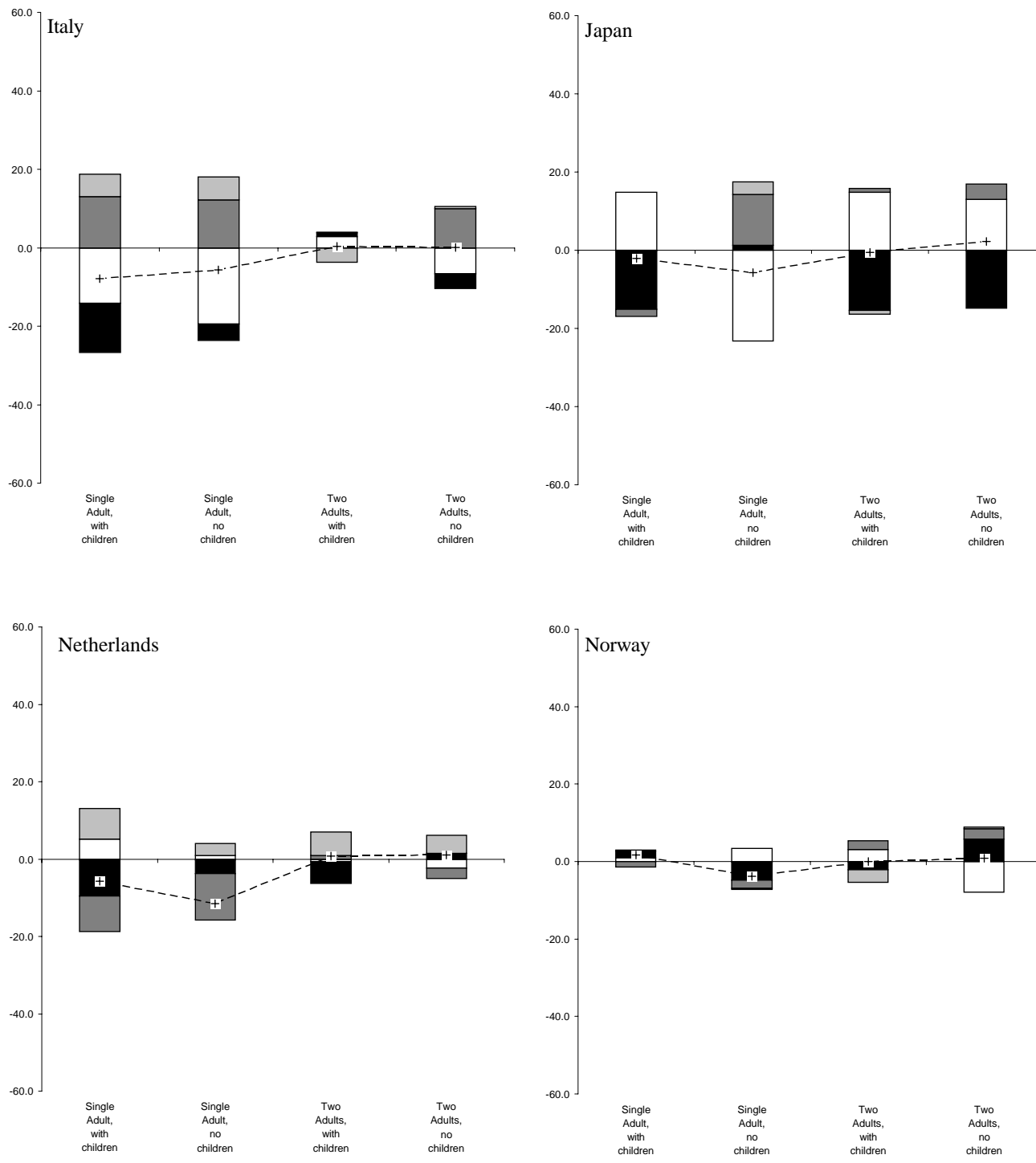


\section{$\mathrm{ECO} / \mathrm{WKP}(98) 2$}

Figure 4.3 (cont.) Contribution of income components to changes in relative disposable income, by family type Equivalence scale $=0.5$
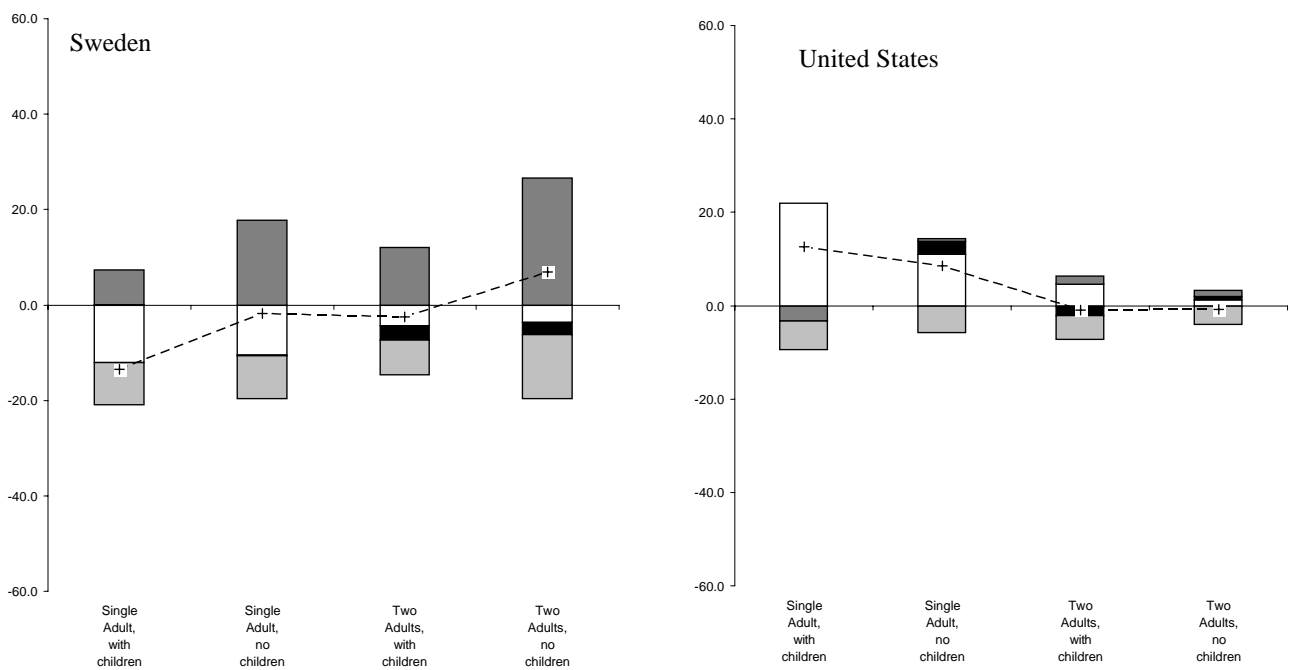

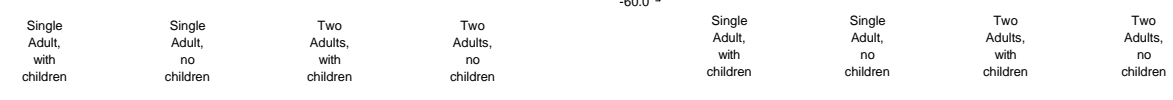

$\square$ EH+ES+EO K+SE $\square T R \quad \square-T A \quad-+--$ Group Mean Diposable Income in Real Terms

Source : $\mathrm{OECD}$

1. The dotted line represents the growth rate of the relative income by household group (i.e., the ratio of the average disposable income of the specific group relative to the population mean).

To calculate the contribution of each income sources by group, the following procedure was carried out :i) for a given group, the growth rate of each component of income was calculated;

ii) this growth rate was then expressed as a ratio of the growth rate of the mean disposable income of the total population; and iii) the resulting relative growth rate was then weighted by the importance

of each income component in the disposable income for the group considered. For each household group, the sum of the contribution is equal to the growth rate of the relative income (See Annex 2). 
ECO/WKP(98)2

Figure 4.4. Contribution of income components to changes in relative disposable income: non-working households

A. Young household heads

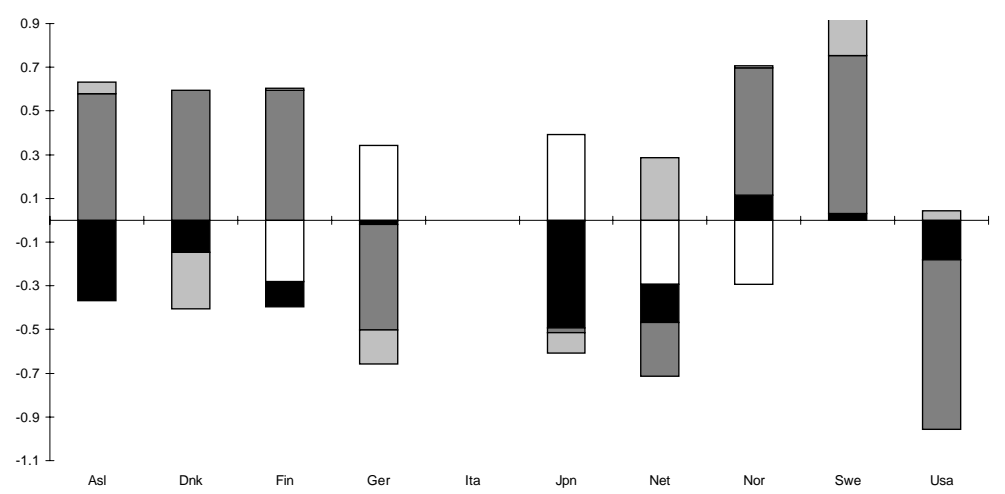

B. Prime age household heads

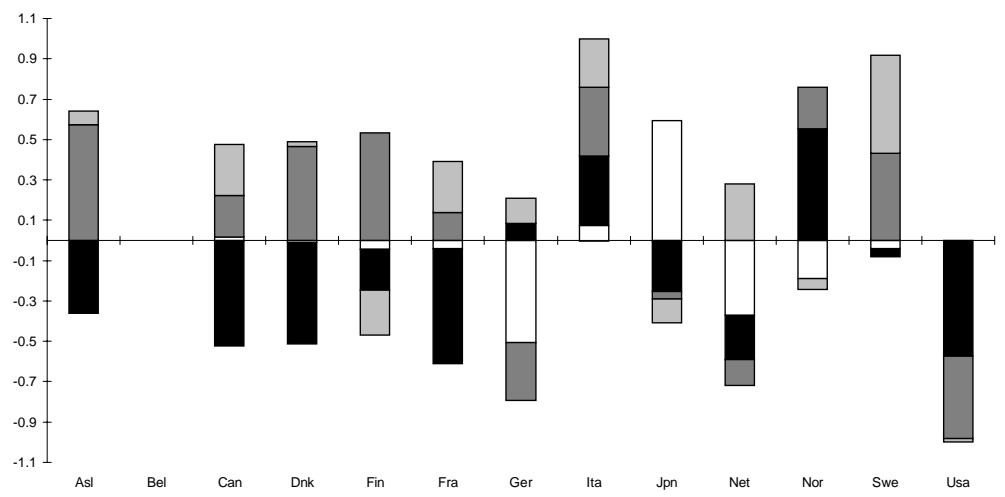

C. Older working age household heads

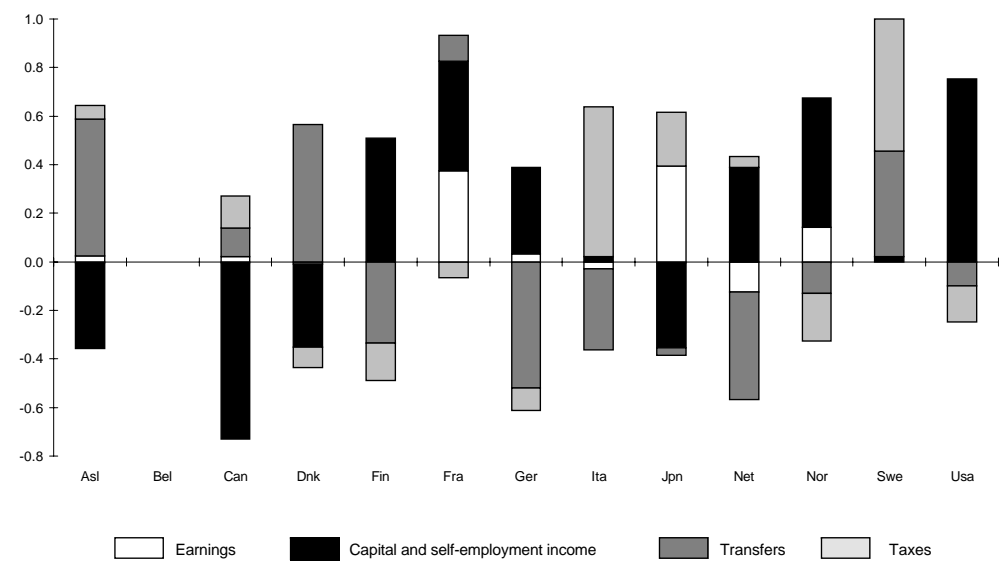

Source: OECD. 
ECO/WKP(98)2

Figure 4.5. Contribution of income components to changes in relative disposable income: children and single earner households with children

A. Children

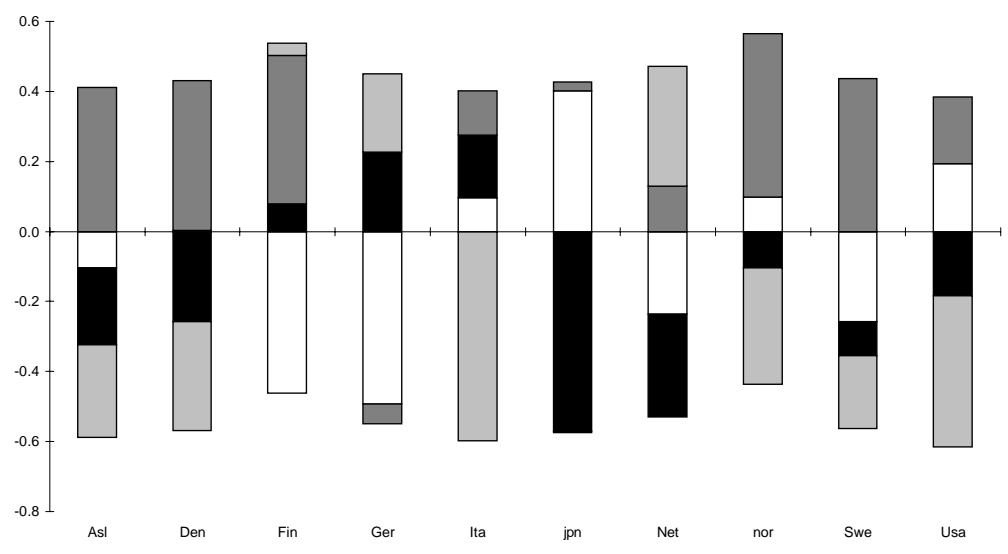

B. Single earner households with children, single parent

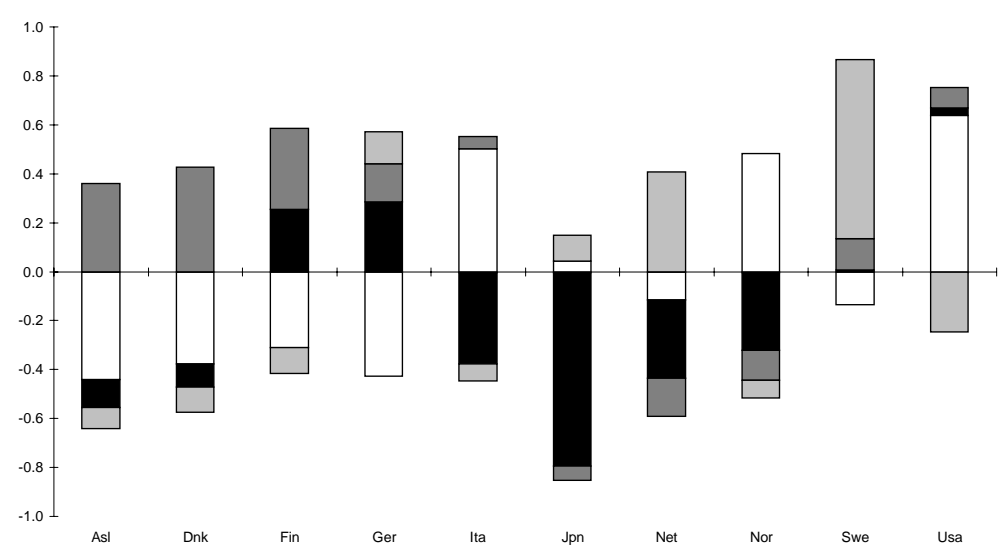

C. Single earner households with children, two parents

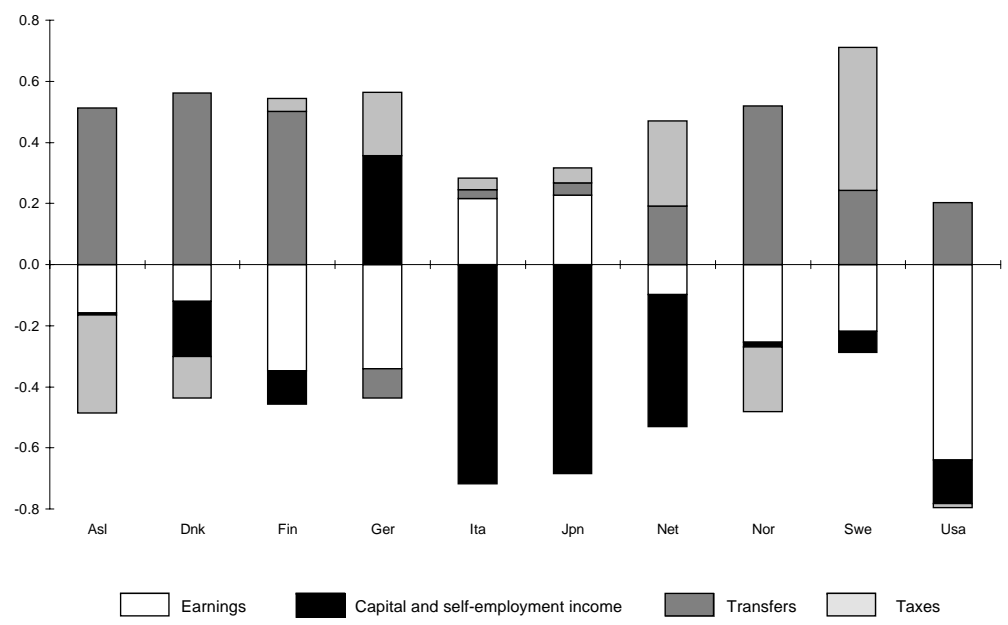

Source: OECD. 
ECO/WKP(98)2

Figure 4.6. Contribution of income components to changes in relative disposable income: non-working households with heads over 65 (the retired)

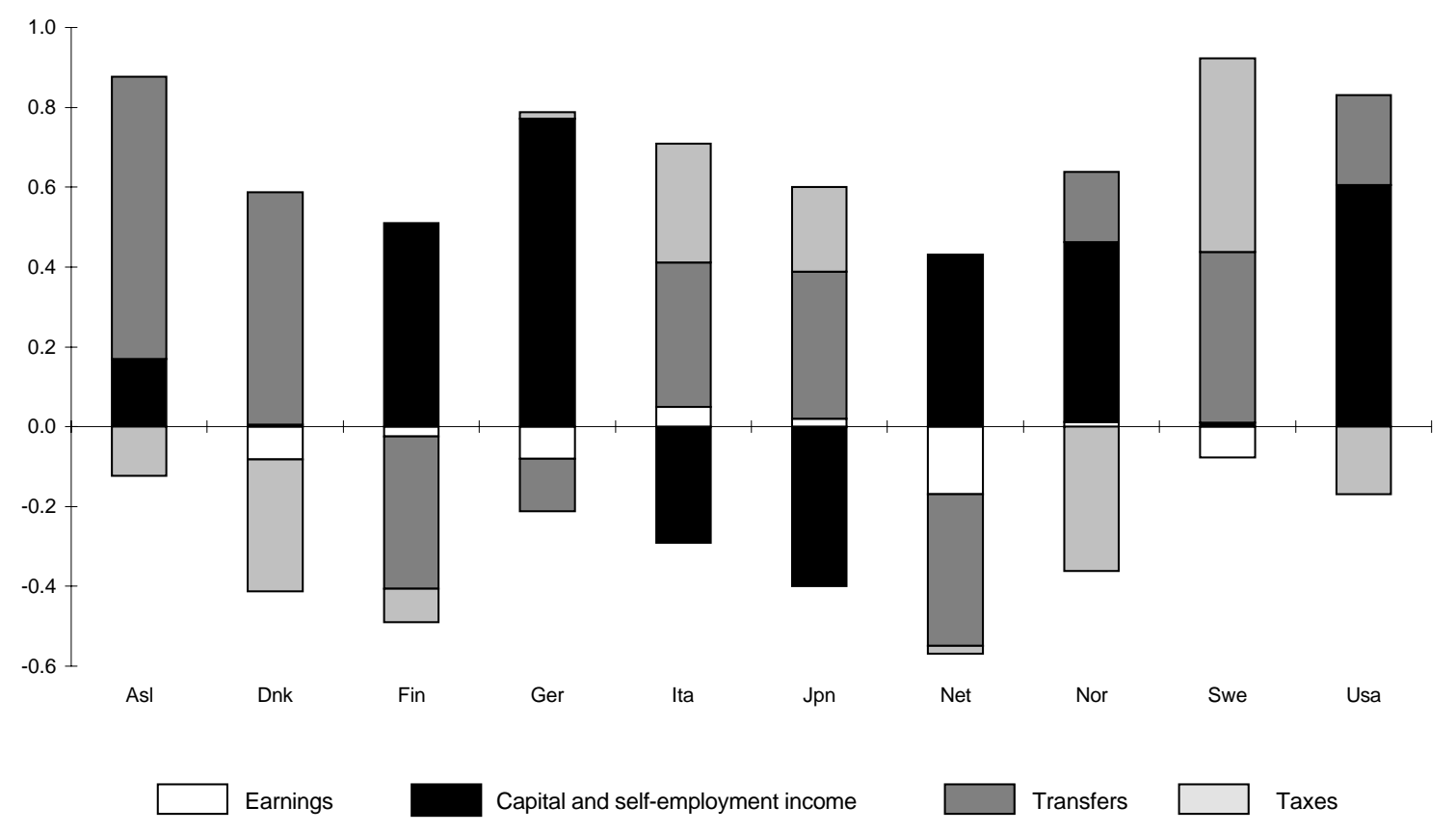

Source: OECD. 


\section{ANNEX 1. DATA, CONCEPTS AND METHODS}

\section{The source and nature of the data}

1. Detailed data on the distribution of household disposable income have been collected for thirteen countries (Australia, Belgium, Canada, Denmark, Finland, France, Germany, Italy, Japan, the Netherlands, Norway, Sweden and the United States) by sending a common questionnaire to experts in each country. These data have been decomposed by type of income, age of individuals and a variety of household characteristics.

2. Data were drawn from national sources rather than international data sets based on comparable definitions -- such as those in the Luxembourg Income Study data files, which were used by Atkinson et al. (1995) -- because this allowed longer time periods to be studied. An effort has been made to harmonise concepts by using common terms of reference for the questionnaire sent out. Levels of income inequality based on the current data set (measured by the Gini coefficient) are, in fact, similar to those based on the Luxembourg Income Study (Table A1.1) ${ }^{38}$. Nevertheless, the lack of consistent crosscountry definitions for components of income, population coverage, etc. and methods of treatment of certain observations $^{39}$ makes cross-country comparisons of the degree of inequality or poverty less reliable.

\section{[Table A1.1 Comparison of inequality indices: Luxembourg Income Study and the OECD questionnaire]}

3. Data were requested for three periods: the mid- to the end 1970s, the early to mid-1980s and the early 1990s (see Table 2.1 in the main text for precise years). However, for Belgium, Denmark, Finland, France, Germany, Italy, Japan and Norway, the earliest years range from 1979 to 1986 and for these countries the time span is only around ten years.

4. The general characteristics of the data sources are summarised in Table A1.2. As can be seen, the nature and purpose of the surveys differ across countries: it is regular household surveys in Australia, Canada, Italy, Japan and the United States; a panel survey in Germany; and tax returns and social insurance files for Belgium, Denmark, France, the Netherlands, Norway and Sweden. This means that data on taxes are recorded in these last four countries, but in the others they are either survey-based or imputed with the help of a national micro-simulation model.

\section{[Table A1.2 Characteristics of surveys and sample size]}

5. The population coverage of the surveys is, in general, the resident non-institutional population. Sample sizes vary considerably, from over 75000 households in the Netherlands to 4600 in Germany. The smaller the sample size, the greater the probability of sampling error -- i.e. the sample may not be perfectly representative of the entire population -- and, for some countries, small changes over time may

38. Inequality is significantly higher in Australia, Belgium and Germany and significantly less in the Netherlands on the basis of this questionnaire.

39. For example, zero incomes were treated as "non-observations" in Belgium, Germany and the Netherlands because all individuals have access to several assistance benefits. 
not be statistically significant. For example, studies in Canada (sample size around 45000 households) suggest that changes in Gini coefficients are only accurate up to 2 decimal points (Zyblock, 1996). Margins of error will be higher in countries with significantly smaller samples, such as Australia and Germany. This problem is compounded for decompositions by household type, particularly when considering the sub-population of the poor, which further reduces sample size.

6. There are often measurement problems at the extremes of the distribution. Many countries have experienced an increase in the degree of apparent poverty, for example in the form of begging in the streets and the homeless. Household surveys usually fail to pick up individuals who do not have a fixed residence. However, estimates of the number of homeless suggest that this would not make a substantial difference to the results in terms of the overall distribution, although it might possibly be somewhat more important for measures of poverty (OECD, 1997a). The following rates of homeless (defined as being without shelter or in receipt of public and voluntary/social accommodation services) in per cent of the total population were reported for 1991-92: Belgium, 0.3; France, 1.1; Germany, 1.3; Italy, 0.2; the Netherlands, 0.2; the United Kingdom 1.2. For the European Union as a whole the rate was 0.75 per cent although this probably underestimates the true number (it excluded those receiving informal assistance) (OECD, 1996).

7. The data are based on cross-sectional surveys ${ }^{40}$. The data therefore compare "snapshots" of the distribution of income for individual years. The samples change between periods: for example, individuals in the bottom 5 per cent of the distribution in one period are not necessarily the same as those in the second period. This "static" description of the income distribution thus does not take into account dynamic changes in income over time.

8. Problems of under-reporting of incomes exist for all countries. While these problems are small for household earnings, they are much more important for other components of income. Self-employment income differs substantially in definition across countries. Under-reporting of capital and property incomes is often significant (Belgium and Italy appear particularly affected). The degree to which this is the case is difficult to judge, and may be concentrated in certain groups. Studies in the United States indicated that it was greatest among the high-income elderly. As reported in Atkinson et al. (1995), p. 36 “... adjustments in the United States for non-reporting all types of income among the elderly in the 1973 Current Population Survey ... indicate that the overall incomes of the elderly would increase by 37 per cent if accurately reported compared to about 9 per cent for the population as a whole (Radner, 1983). The difference was mostly due to property income non-reporting among the high-income elderly as well as under sampling."

9. Transfer payments are also often under-reported in survey data, particularly for income-tested benefits. For example, unemployment, supporting parent and widows benefits in Australia has been under-reported by some 30 per cent; in the United States the overall under-reporting of income transfers is about 17.5 per cent, and 25 per cent for assistance-type payments; and in Canada only about 50 per cent of provincial assistance benefits are reported (Atkinson et al., 1995).

10. Finally, in some countries, data on tax payments have either not been collected or have been found to be severely in error. In some cases, they have been calculated by simulation models (Germany, Italy and the United States). However, such calculations can lead to their own errors, particularly in tax systems which are complex or provide opportunities for avoiding or evading tax. For France, market

40. The two German data files are from a panel survey, but were treated as cross-sectional. 
income data are net of social security contributions and, consequently, only direct taxes on income are reported.

11. For three countries there are breaks in data series, due to changes in the income concept or changes in the sampling procedure:

- For the Netherlands, there were changes in the tax system in the early 1990s, but data for 1985 were made consistent with those for later years. The change over the entire period was established by linking the growth of the various indicators from 1977 to 1985 (old tax system) with the growth from 1985 to 1994 (new tax system).

- For Sweden, there was also a change in the tax system between 1990 and 1991 but there was no way of linking the period 1975 to 1990 with the period 1991 to 1995 . In this case, the change over the entire period was established by linking the growth of indicators in the earlier period with the growth in the later period. Changes from 1990 to 1991 are, thus, not included.

- In Italy, the organisation undertaking the income survey changed in the early 1990s and national authorities believe that the sampling and measurement of lower income households is now more accurate. There is no way to adjust for this effect.

\section{Cyclical effects}

12. The years for which data were collected are not always at the same cyclical position. All countries except the United States experienced some increase in unemployment over the period. For the countries with data extending back to the mid-1970s, the increase in unemployment was concentrated in 1975-1985 in Australia, Canada and the Netherlands, and unemployment remained broadly stable or declined in 1985-95. In contrast, Finland and Sweden experienced a sharper increase in the period from the mid-1980s to the mid-1990s.

13. Higher unemployment tends to increase the inequality of earnings or market income (Sharpe and Zyblock, 1996; Cutler and Katz, 1991). Sharp and Zyblock (1996) estimate that one-third of the increase in inequality for market income in Canada can be attributed to unemployment over the period 1976-94, while Johnson (1995) finds that unemployment affected incomes the most in the lower deciles. Cutler and Katz (1991) find that, for the United States, the increase in inequality in the 1980s is larger than what could be "explained" (based on past relationships) by changes in unemployment. This relationship between unemployment and income inequality did not appear to hold for Italy, where inequality fell in the downturn and increased in the upswing (Brandolini and Sestito, 1994). Such effects on the distribution of market income have been partly offset by movements in transfers and taxes -- the extent depending on the institutional arrangements in individual countries. Thus, a comparison of inequality between two periods with different unemployment rates may give a false picture of the underlying change in inequality. However, there is no statistical relation between changes in inequality indices (at the level of disposable income) and changes in a variety of labour-market indicators across the countries reported here, suggesting that, for cross-country comparisons of trends in income inequality, labour-market effects may be swamped by other factors. 


\section{The income concept and income unit}

14. The key income concept used in the study is that of equivalent household disposable income per household member. The following paragraphs first define the income components which are considered and their limitations. It then explains how income is adjusted to allow for household size and possible economies of scale associated with the sharing of resources within a household.

\subsection{Components of household disposable income}

15. The income unit is the household, defined as a group of persons sharing a set of common resources, not necessarily related by blood or marriage. Household disposable income is defined as total market income (income from labour, capital and private transfers), plus income transfers from general government, less income taxes and social security contributions. Specifically, four income components are identified ${ }^{41}$ :

- earnings (ER): the salary income of the household from dependent employment (excluding employers' contributions to social security, but including sick pay paid by social security);

- capital incomes $(\mathrm{K}+\mathrm{SE})$ : occupational pensions and all kinds of private transfers $(\mathrm{K})$ plus self-employment incomes (SE).

- social security transfers (TR): accident and disability benefits, social retirement benefits (from public sources), unemployment benefits, maternity allowances, child and/or family allowances (from public sources), and all income-tested and means-tested benefits;

- taxes (TA): direct taxes and employee social security contributions paid by households.

To the extent possible, definitions used in calculating these income sources were as close as possible to those adopted in Atkinson et al. (1995). For certain countries this disaggregation was not possible. In Canada and Germany self-employment income was included in earnings and, in Norway, unemployment insurance payments were also treated as part of earnings. Data using this breakdown were not included for France, reflecting a range of definition differences.

16. Household disposable income $(W)$ is defined as:

$$
\text { [1] } W=E R+(K+S E)+T R-T A
$$

and market income $(\mathrm{M})$ is defined as:

$$
\text { [2] } \quad M=E R+(K+S E) \text {. }
$$

\subsection{Limitations of this income concept}

17. Household disposable income is only a partial measure of consumption or welfare of households. First, the data measure only cash incomes, thereby excluding any income received in kind.

41. Greater detail is available from the data sets: earnings received by the head of household, spouse and other household earners, and both capital and self-employed income can be identified separately. 
This means that, for example, the implicit rents in the case of house ownership and certain capital gains are often not included in the data. Data on imputed rents are available for the Netherlands and Sweden, but were not included. Capital gains are usually realised capital gains on the sale of assets rather than a reflection of the yearly change in the value of assets. Large lump-sum receipts may in this case artificially widen the distribution. For these reasons, in Australia, private pension arrangements, which often take the form of a lump-sum payment on retirement rather than an annuity, have been excluded. Since these income components are likely to be concentrated in upper-income groups or older households which have accumulated assets, the level of income distribution and the age profile of income will be affected.

18. The data also do not take into account most government services provided at subsidised or zero cost. Depending on the structure of programmes, certain households may benefit more than others. For example, free child-care may benefit a two-earner household more, while free or subsidised services to older persons may be important in reducing their needs for market services ${ }^{42}$.

19. The data refer to annual incomes. These are recorded directly in most surveys, but other surveys measure weekly or monthly incomes which are then aggregated to annual income (e.g. Australia, Germany). Some individuals, with low or negative income because of declared losses in self-employment in one particular year, are classified as poor. For example, Canada in 1990 had over 40000 households and 115000 persons with either zero and negative income and none of these were homeless -- 42 per cent of individuals were employed, 26 per cent were homeowners, most of them mortgage-free, and 17 per cent had university degrees ${ }^{43}$. At the top end, some individuals may receive large lump-sum payments pushing up their income temporarily, followed by a sharp fall in the following years. Thus, data in the highest and lowest deciles may contain some households which would not be included if a longer view were taken, and exclude some which would be.

20. Finally, income measures do not take into account other aspects of poverty encapsulated in the term "deprivation" (Townsend, 1979). This encompasses a broad range of factors -- such as literacy, absence of skills, poor health or handicaps, poor housing conditions, lack of resources to search for jobs -which may affect individuals' capacity to move out of poverty. There is concern that the importance of deprivation has been increasing, becoming concentrated in urban areas and among population groups which remain at the margin of society despite improving economic conditions (see Gilles-Simon and Legros, 1997).

\subsection{Adjustments for household size and the definition of the distribution}

21. Equivalent household disposable income per individual and the associated distribution are established in the following way (see Box A in the main text):

42. In fact, the level of consumption -- particularly where it is defined to include all consumption rather than just market goods and services -- may be a better indicator of welfare than income. Many studies show that the distribution of consumption of market goods and services alone is much narrower than the distribution of household disposable income (Slesnick, 1993 and 1994) reflecting in part the smoothing of consumption over the life cycle. Recent estimates in Denmark show that public services provided by the government decrease inequality for the age group 23-59 as measured by the Gini coefficient by around one-third (Danish Ministry of Finance, 1997).

43. Households with negative income were excluded from the data used in this study (see below). 
- First, the sum of the disposable incomes of all household members equals household disposable income.

- Second, household disposable income is adjusted for differences in household size to obtain equivalent household disposable income. In the tables presented in the main paper, household disposable income is divided by the square-root of the number of persons in the household. (For example, the equivalent income of a four-person household is household income divided by two.) This is an adjustment that recognises some "economies of scale" within the household. Alternatively, household incomes are simply divided by the number of individuals, giving per capita income. This assumes no "economies of scale"

- Third, equivalent household income is attributed equally to all individuals in the household, even though the incomes they receive as individuals may be different. Children and spouses are assumed to benefit equally from household income, even though a number of studies suggest that the relative control over family resources can differ significantly among members, which can result in quite different patterns of individual consumption within the household (Lundberg and Pollak, 1996).

- Finally, individuals are ranked by the (ascending) level of their equivalent disposable income. This is equivalent to ranking by households weighted by household size. This population weighting is sometimes referred to as "person weights", as opposed to "household weights" (Atkinson et al., 1995).

\subsection{Specific adjustments to the data}

22. In many surveys, to maintain anonymity, a ceiling is set on the highest recordable income of individuals. Those individuals with incomes above the ceiling are assigned incomes at the ceiling, a practice referred to as "top coding". For example, in the publicly available income distribution data of the Census Bureau of the United States, the top code limit for individual earnings (from the longest job) was as follows:

$\begin{array}{lcrr}\text { Year } & \underline{1974} & \underline{1984} & \underline{1995} \\ \text { Value (\$ thousands) } & 50 & 100 & 150 \\ \% \text { of individuals top coded } & 0.4 & 0.5 & 0.8\end{array}$

In addition, the Census Bureau changed the method of top coding. Starting in 1989, incomes above the top coding limit were replaced by the average income of individuals above this ceiling rather than by the top code limit (as done until then). To improve consistency over time, the data used in this study allow for changes in the top-code values reported above, but attributes the value of the limit to individuals with incomes above the limit. The share of individuals who were top coded increases slightly over the period suggesting that the increase in measured inequality may be biased downwards. The use of top coding can affect the apparent distribution of income. On the one hand, if the top code is left unchanged and income gains above that limit are particularly strong, the change in inequality will be underestimated. On the other hand, raising the top code can result in a spurious increase in inequality.

44. The former case uses an "equivalence of scale elasticity" of 0.5 , the latter case one of 1.0. 
23. The same issue arises at the bottom of the distribution. Some countries (Belgium, Germany and the Netherlands) have eliminated observations with zero income or incomes below a specific value. In the case of the Netherlands, this was because households declaring zero income were often individuals working in another country but residing in the Netherlands. For Germany those with incomes less than the social minimum (BSHG) were excluded for similar reasons. For other countries, zero or negative values of equivalent disposable and market income per household member were set at a small positive number to allow calculation of certain inequality indices. More specifically the following procedure was followed: $i$ ) any market income component $(\mathrm{ER}, \mathrm{K}+\mathrm{SE}$ ) which was negative was set to zero, and market and disposable income recalculated; ii) any value of market income lower than 1 per cent of mean market income was set at 1 per cent of mean market income; iii) any value of disposable income lower than 1 per cent of the mean disposable income was set to 1 per cent of mean disposable income.

\section{Implications of the specific household and income concepts used}

\subsection{Implications of the household unit}

24. Households or families, rather than the individual, are the income unit used in national surveys. This affects the level of income inequality and, if household size changes, its evolution. An increase in the size of the income unit lowers the degree of income dispersion. For example, if grandparents live with their children and their pensions contribute to family income, this individual would be treated as part of the household in some countries or as a separate income unit in others; in this second case, if the income of this person is low, the income distribution would widen. According to Goodman et al. (1997), the number of people with low incomes (defined as 50 per cent of average incomes) would decline by around one-quarter in the United Kingdom if households, rather than narrowly-defined families, were used. Also, the proportion of single non-pensioners among the poor is 8 per cent on a household basis, but over 20 per cent on a family basis.

25. The definition of the income unit in Sweden requires particular attention. Swedish data are based on tax returns, but individuals over the age of 18 fill in a separate tax return and are treated as independent families, even when living with their parents ${ }^{45}$. This differs from most other countries where young people living their parents are considered as member of the same household. Since young people living with their parents -- for example, while continuing their education -- often have low reported income, the share of the age group 18-25 in the bottom quintile will be higher (and the share of other age groups lower) in Sweden than elsewhere. The share of the age group 18-25 in the bottom decile has risen sharply in Sweden over the past two decades, but it is difficult to distinguish between the effects of labour-market conditions and longer stays in post-secondary education. Individuals in households with a head below the age of 30 will also have lower average incomes and a higher concentration in the lower quintile in Sweden. Since many of these individuals are not working, the share of the non-working households within this group increases.

\subsection{Implications of choosing different equivalence scales}

26. The rankings of individuals in terms of their equivalent household disposable income depends to some extent on the equivalence scale chosen, which interacts with the household to which they belong.

45. It should be noted that, in the other countries as well, those below age 18 living alone but supported by their parents are treated as a separate household. 
For example, individuals belonging to larger households would rank higher in the distribution assuming an equivalence scale elasticity of 0.5 than using an equivalence scale of 1 , i.e. than under the assumption of no economies of scale ${ }^{46}$.

27. In particular, as some studies have shown, the income of the elderly (who generally have small families) relative to children depends significantly on assumptions on scale economies. Buhmann et al. (1988) examined the impact of alternative equivalence scales for ten different countries and concluded (p. 140) that: "Choice of equivalence scale can systematically affect comparative absolute and relative levels of countries (or groups within countries) with respect to measured inequality and poverty. Because of these sensitivities one must carefully consider summary statements and policy implications derived from cross-national comparisons of poverty/and or inequality." However, in practice, this effect was not large considering the effects of equivalence scales on the ranking of the ten countries studied, they concluded that (p. 128): “... equivalence scales have in general no great effect on the rank order of measured inequality as long as average family size is not extremely large." Changes over time will also depend on changes in family size. Burkhauser et al. (1996) used the LIS and alternative equivalence scales to examine the sensitivity of measures of inequality and poverty in Germany (1984) and the United States (1986). The findings suggest that while overall inequality and poverty levels were not sensitive to the equivalence scales used, the relative income and poverty levels of vulnerable groups of the population -- especially older and single people -- within a country, and comparisons of these groups between the two countries, were quite sensitive to the equivalence scale used.

28. Another alternative would be to weight each household equally, a method used by the US Census Bureau. Compared to the practice in this paper, this generally leads to a smaller number of individuals receiving low equivalent income, because average household size tends to be larger at the bottom than at the top of the distribution.

\section{Measuring income inequality and poverty}

29. A variety of approaches can be employed to summarise the characteristics of income distribution and its evolution over time: the Lorenz curve and various inequality indexes (such as the Gini coefficient) have been widely used for this purpose. These are described below.

\subsection{Inequality indices}

30. Income distributions can be summarised by an index number. However, these do not all give the same results as they are more or less sensitive to movements in different parts of the distribution. The following four indices are presented in Table 2.1 and used elsewhere in the report.

- The Gini index is calculated as:

46. See Annex 2 for a description of the sensitivity of the results to different assumptions about the equivalence elasticity. 


$$
\begin{aligned}
\operatorname{Gini}=\left(\frac{2}{\mu \cdot n^{2}} \cdot \sum_{k=1}^{n} k \cdot W_{k}\right) & -\frac{n+1}{n}=\frac{2 \operatorname{cov}\left(W_{k}, \frac{k}{n}\right)}{\mu} \\
& =\frac{\frac{2}{n} \sum_{k=1}^{n}\left(W_{k}-\mu\right) \cdot\left(\frac{k}{n}-\frac{1}{n^{2}} \sum_{k=1}^{n} k\right)}{\mu}
\end{aligned}
$$

where individuals are ranked in ascending order of disposable income $(k=1,2, \ldots . n$, where $n$ is the total number of individuals); $\mu$ is the arithmetic mean of disposable incomes per equivalent household member.

31. The Gini coefficient may be derived from the Lorenz curve, which plots cumulative shares of the population, from the poorest upwards, against the cumulative share of incomes that they receive. If incomes were equally distributed, the plot would trace a diagonal $45^{\circ}$-line ("line of perfect equality"). At the other extreme -- if the richest unit received all income -- the Lorenz curve would lie along the horizontal axis, and then along the vertical axis at the 100 per cent income share ("line of perfect inequality"). The Gini coefficient is defined as the area between the Lorenz curve and the $45^{\circ}$-line, taken as a ratio of the whole triangle.

- The SCV (Squared Coefficient of Variation) index is calculated as:

$$
S C V=\frac{\operatorname{var}\left(W_{k}\right)}{\mu^{2}}=\frac{\frac{1}{n} \sum_{k}\left(W_{k}-\mu\right)^{2}}{\mu^{2}}
$$

- The MLD (Mean Log Deviation) index is calculated as:

$$
M L D=\frac{\sum_{k} \log \left(\frac{\mu}{W_{k}}\right)}{n}
$$

where log is the natural logarithm:

$$
\mu=\frac{\sum_{k} W_{k}}{n} ; \text { and } n \text { is the total number of individuals. }
$$

- The Atkinson index is calculated as:

$$
\text { Atkinson }=1-\left[\frac{1}{n} \sum_{k}\left(\frac{W_{k}}{\mu}\right)^{1-a}\right]^{\frac{1}{1-a}}
$$


where a is a parameter (a not equal 1). The higher a, the higher the weight given to changes in the lower part of the distribution. The value for a used in this study is 0.5 .

32. It should be noted that these four indices have different ranges; all indices have a lower bound of zero, but the upper bound is 1 for the Gini and the Atkinson indices, infinity for the SCV and $(1+\log (100)) \log (\mu)$ for the MLD ${ }^{47}$. Thus, changes of similar magnitude may indicate quite different changes in the degree of inequality depending on the indicator. In addition, each index differs in its sensitivity to changes at various points in the distribution. This is shown in Figure A1.1 which plots, on the basis of a hypothetical distribution, the change in each index when average income in each decile was decreased by 20 per cent. Relative to other indices, the Gini coefficient is less sensitive to changes in income at the two extremes of the distribution. The MLD and the Atkinson index (0.5) are more sensitive to changes at the bottom of the distribution, while the opposite occurs for the Squared Coefficient of Variation (SCV).

33. Wherever indices move in different directions the distribution may, for example, narrow at the top and widen at the bottom and the Lorenz curves may cross. In these cases, statements about whether inequality has increased or not depends on value judgements as to whether the narrowing at the top is "worth more", in welfare terms, than the "cost" of an equivalent widening at the bottom. In the dataset used, the Lorenz curves, in fact, crossed in only a few cases and in these cases the differences were below levels of significance normally used in international comparisons (Atkinson et al., 1995) ${ }^{48}$.

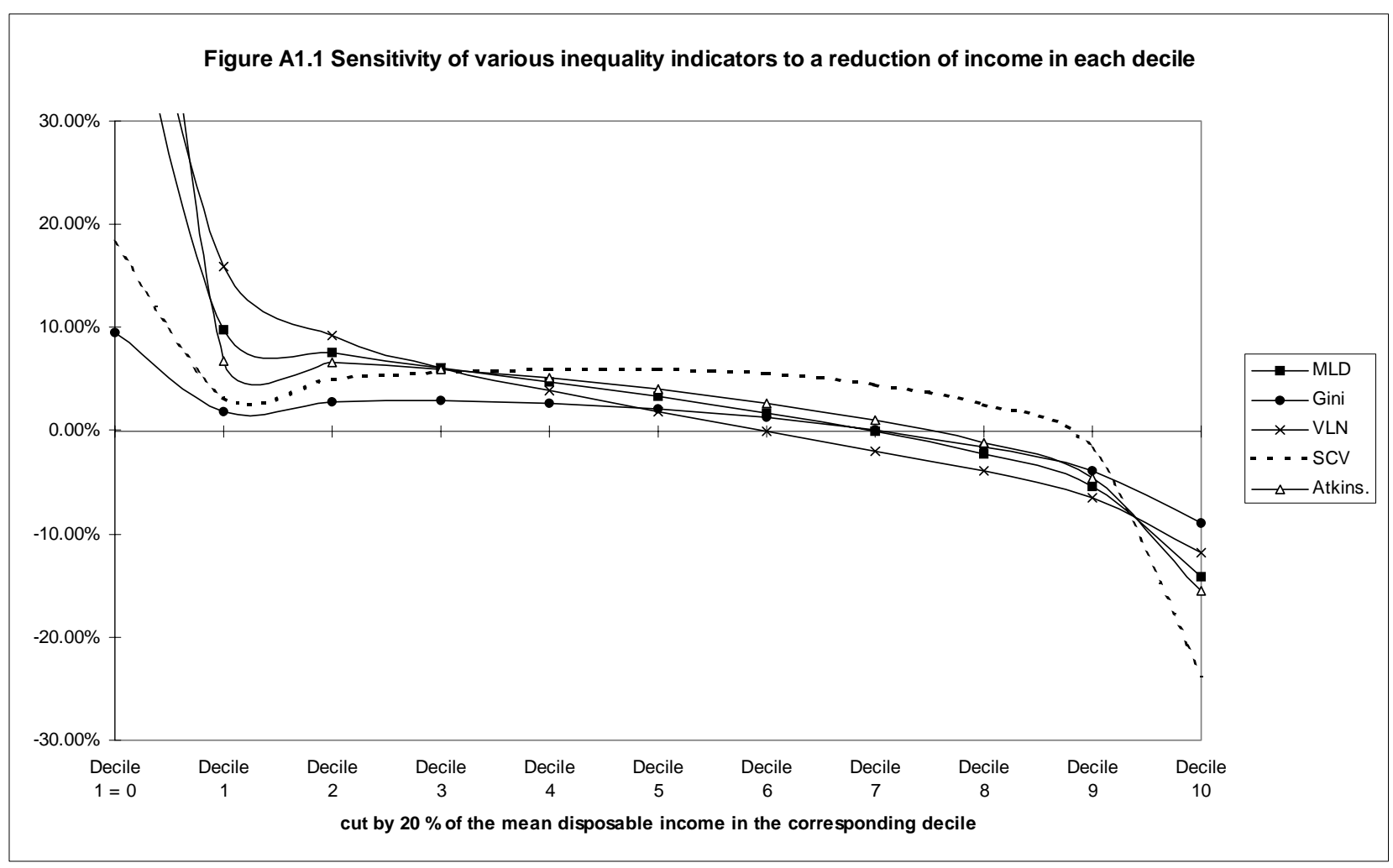

47. Data in tables have been multiplied by 100 .

48. Canada was the only exception. 


\subsection{Measuring poverty}

34. Data on overall poverty were available for all countries from the OECD questionnaire (Tables 5.1 and 5.2) and, for five countries, from the Luxembourg Income Study data files (Table 5.7). These measures of poverty are broadly similar, although the time periods differ slightly.

35. The description of poverty uses several measures. The first draws on data on individuals in the bottom quintile broken down by work attachment and household type. The bottom quintile is not an indicator of aggregate poverty, as it is always one-fifth of the population by construction, but it can throw light on both the risk of poverty and the patterns of poverty by group. The second, known as the "head count" ratio $(H)$, is the percentage of persons with an equivalent household disposable income below a poverty threshold. This allows both overall poverty and poverty among groups to be studied. Relative poverty thresholds were established as a fraction of median income of the society as a whole. The usual threshold is 50 per cent of the median, but in some cases 40 and 60 per cent of the median are shown as well. As income distributions are generally skewed to the left, median income is less than mean income. Poverty rates using the median are therefore lower than those using the mean. Where income gains at the top of the distribution lead to a widening in the gap between mean and median income, poverty based on median income would increase less than if mean income were used. For the same reason, the median is also less sensitive to assumptions on the top coding of the data.

36. The third is the average income gap (I): the difference between the poverty threshold and the disposable income of the poor, as a percentage of the poverty threshold:

$$
I=\frac{\left(z-\mu_{p}\right)}{z}=\frac{\left(\frac{1}{p} \sum_{k=1}^{p}\left(z-W_{k}\right)\right)}{z}
$$

where $\mathrm{z}$ is the poverty threshold, $\mu_{p}$ is average income of the poor and $W_{k}$ is individual income.

37. The fourth is the Sen index $(S)$, defined as the head-count ratio multiplied by the sum of the income-gap ratio and the Gini coefficient of the poor weighted by 1 minus the income gap ratio. Thus:

$$
S=H \bullet[I+(1-I) G p]
$$

where $G p$ is the Gini coefficient of the poor.

38. This composite poverty indicator takes into account both the intensity of poverty and the distribution of income among the poor. The Sen index can be interpreted as the weighted sum of poverty gaps of the poor, and lies between 0 (when everyone has an income above the poverty threshold) and 1 (when everyone is below the poverty threshold and the distribution among the poor is characterised by perfect inequality). $S$ equals $H$ in the case of perfect inequality among the poor (i.e. $G p=1$ ), and $H^{*} I$ in the case of perfect equality among the poor. The closer $S$ gets to the head count ratio $H$, the more severe the situation of the poor becomes. 
39. The structure of poverty by household type can be described in two ways ${ }^{49}$ :

- The poverty rate: this is defined as poor individuals in a specific group as a ratio of the total number of individuals in that group. Poverty is defined in two ways. In Section 5.3 (Table 5.3) individuals are poor if they are in the bottom quintile. Thus, the poverty rate for non-working single-adult households in Australia (1993/4) is 86.8 per cent -- i.e. 86.8 per cent of this group are in the bottom quintile. In Section 5.4 persons are poor if their equivalent income falls below 50 per cent of median equivalent income.

- The poverty structure: this shows who the poor are and is defined as the proportion of the poor which belong to a specific group. Again the definition of total number of poor differs between Sections 5.3 and 5.4: in the former it is the number in the bottom quintile; in the latter it is the total number of individuals below the poverty threshold. Thus, the poverty share in Section 5.3 for non-working single-adult households in Australia (1993/4) is 12.2 per cent -- they make up 12.2 per cent of all individuals in the bottom quintile.

\section{Decomposing inequality by income component}

40. Incomes have been broken down by income source as explained in Section 3.1. The following section provides further details on methods used for assessing which income components have contributed the most to the change in the income distribution.

\subsection{Income shares by decile groups}

41. Table 3.1 shows the share of each income component received by the bottom three deciles, the middle four deciles and the top three deciles in the latest year, and the change in this share over time ${ }^{50}$. Individuals have been ranked on the basis of their equivalent disposable incomes and then aggregated into the three groups just mentioned. Incomes were disaggregated into the four components listed in Section 3.1 and then summed across individuals in each of the three decile groups. The share of the income component going to each group was then calculated. This method does not allow estimation of the contribution of income sources to the level and change of income inequality at the aggregate level.

\subsection{Estimating contributions to inequality: the "adding in" method}

42. A commonly used method successively adds various income sources and calculate aggregate inequality indices after each step. The contribution of each income source to inequality is measured by the change in the inequality indicators used. This has been carried out in Table 3.2 in the main text, which shows the change in inequality indicators when net taxes and transfers are added to market income. As the table demonstrates, the contribution of income components depends on the index used. Some of the advantages and disadvantages of alternative approaches are described in Box $\mathrm{C}$ of the main text. A major

49. Note that sample sizes are small for some groups, increasing the risk of sampling error. In the light of this, only the head count ratio was calculated.

50. A component is equally distributed across the three decile groups if 30 per cent goes to the bottom and top groups and 40 per cent to the middle. However, the impact on overall inequality will depend on the degree of inequality of the other components. If market incomes are unequally distributed, transfers will have an equalising effect if they are less unequally distributed than market income. 
problem with this approach is that the impact attributed to an individual component will depend on the order in which it is considered ${ }^{51}$. No single ordering of components is "appropriate" in all circumstances.

\subsection{Shorrocks decomposition rule}

43. Chapter 3 also uses a decomposition rule permitting an additive decomposition of inequality changes across the components of disposable income (Shorrocks, 1982). This approach is methodologically superior to alternative methods (including the one outlined in the preceding paragraph) because it is additive and the results do not depend on the index used. To obtain a unique decomposition rule, Shorrocks imposed six a priori principles described in Box B of the main text. Imposing these restrictions yields proportional contributions $s_{k}$, which are invariant of the inequality indicator used and additive:

$$
\text { [1] } \quad S_{k}=\frac{S_{k}}{I} \quad \text { and } \quad \sum^{k} S_{k}=I
$$

where $S_{k}$ is the absolute contribution of each component in terms of a chosen inequality index $I$.

44. These proportional contributions $\left(s_{k}\right)$ of each component to disposable income are shown for the beginning and end of the period in the left-hand panel of Table 3.3, adding up to 100. Contributions with a negative sign implies a reduction in total inequality. Negative changes in negative contributions (third row) indicate a stronger equalising effect (or weaker de-equalising effect). The middle panel of Table 3.3 shows the shares of each one of the components in total income, with taxes taking a negative sign. In the case of taxes, a negative change indicates a rise in the tax share.

45. In the right-hand panel, the contribution of each component (left-hand panel) is divided by its share in total income (the middle panel). This may be thought of as the contribution of the income components purged of the effect of its share in total income. A negative sign indicates that the component (e.g. transfers) is reducing inequality; thus, the negative sign for transfers for most countries suggests that, after adjusting for the increase in importance in total income, they are having an equalising effect. In the case of taxes, however, the positive sign indicates a reduction in inequality. The change in this index in the right-hand panel of Table 3.3 shows the marginal impact of the inequality specific to that component on the change in total inequality. Negative changes indicate that the income source (e.g. transfers), given its share in total income, increases its equalising effect (or reduces its disequalising effect). For taxes, however, a positive change indicates that its (equalising) contribution is increasing.

46. Table 3.4 calculates the contribution of income components to changes in the SCV index of inequality, drawing on information in Table 3.3. Table A1.3 shows the links between Tables 3.3 and 3.4 using a numerical example for taxes and transfers in Australia and Finland. As noted in the main text, the Shorrocks decomposition will give the same proportional contributions whatever the index for aggregate inequality used. The following steps are carried out:

51. Consider three income sources, A, B and C, with all individuals receiving exactly the same amount of income component $\mathrm{A}$ while $\mathrm{B}$ and $\mathrm{C}$ are unequally distributed. If $\mathrm{A}$ is considered first, its contribution to inequality is zero since it is equally distributed. In the other orderings, however, it will reduce inequality. Therefore, the contribution of $\mathrm{A}$ varies from zero to negative depending of the ordering of income components. 
- The contributions of taxes and transfers to the SCV $\left(\mathrm{SCV}_{\mathrm{k}}\right)$ in any year are equal to the SCV index multiplied by the proportional contributions $s_{k}$ in the left-hand panel of Table 3.3 (lines 3 and 6 in Table A1.3).

- Changes in proportional contributions of taxes and transfers $\left(s_{k}\right)$ are shown in line 7. Changes in the SCV contributions $\left(S C V_{k}\right)$ are in line 8 and they sum to the total change in the $\mathrm{SCV}$. As can be seen, it is possible to have a positive change in the proportional contribution of a component (taxes) in Table 3.3 and a negative change in the SCV contribution in Table 3.4 (Finland). This can arise because the change of the $\mathrm{SCV}_{\mathrm{k}}$ contribution is affected by both: $a$ ) the change in the proportional contribution $\left(s_{k}\right)$ (assuming the SCV is constant); and $b$ ) the change in the aggregate SCV (assuming the proportional contribution is constant). (See sub-components under line 8.)

- To separate the impact of changes in the shares of each component in total income $\left(S h_{k}\right)$ from the effects of the change in the component-specific inequality, the contribution $S C V_{k}$ in each year can be expressed as $S C V_{k}=\left(S h_{k}\right) *\left(S C V_{k} / S h_{k}\right)$ (lines 9-12); the effect of changes in shares $\left(S h_{k}\right)$ and its component inequality $\left(S C V_{k} / S h_{k}\right)$ to the change in the $S C V_{k}$ are calculated using a shift share analysis (lines 13-14).

\section{[Table A1.3 Contribution of income components to the total change in the SCV index: a numerical example]}

\section{Population sub-groups}

47. To identify groups most affected by changes in the income distribution, the population was broken down according to selected household characteristics and by age of individuals.

\subsection{Household characteristics}

\subsubsection{By work attachment}

48. First, individuals are grouped on the basis of work attachment of their households. Households are identified as having no worker, one worker or two or more workers. No distinction is made between part-time and full-time work.

49. Three additional breakdowns (referred to in the text as breakdowns by household type) are:

\subsubsection{By age of the household head}

50. Four groups by the age of the household head are distinguished: young heads (under age 30); prime-age heads (30-50 years of age); older-working age heads (50-65 years of age); and retirement-age heads (65 years old and over). 


\section{ECO/WKP(98)2}

\subsubsection{By family type}

51. This indicates the presence of children (children/no-children) and the number of adults (one-adult, two or more adults). The term "family" is used for expositional convenience. For most countries the data refer to households rather than more narrowly defined families.

52. The data by household type (7.1.2 and 7.1.3) are further disaggregated by work attachment (7.1) creating 22 groups.

\subsubsection{By age of individual}

53. Individuals were also grouped according to their age into seven groups: $0-17,18-25,26-40,41-$ 50, 51-65, 66-75 and 75 plus. Each individual was attributed the equivalent income of the family to which she or he belongs. This permits an examination of how groups such as children have been faring. Only data for children $(0-17)$ were used in the main text.

54. There are important overlaps between some of the groups. For example, a large share of individuals in retirement-age households also belonged to non-working households without children.

\subsection{Relative incomes and contributions of income components}

\subsubsection{Relative disposable income by group}

55. Relative income for each group is their equivalent disposable income relative to the mean for the total population. The latter is calculated as the mean income of the groups weighted by the shares of each group in the population. To avoid the impact of changing shares of the groups, the weights are those of the earliest period ${ }^{52}$. Changes in group incomes relative to the mean show which groups gain and lose, after controlling for shifts in population structure. The calculation of relative income of group $\mathrm{g}\left(\tilde{y}_{g}\right)$ for each year is as follows:

$$
\text { [1] } \quad \tilde{y}_{g}^{t}=\frac{y_{g}^{t}}{\sum_{g} w_{g}^{0} \cdot y_{g}^{t}}
$$

where $\quad \sum_{g} w_{g}^{0}=1, w_{g}^{0}$ is the weight of group $g$ in the population at the beginning year $(t=0)$ and $y_{g}^{t}$ is the income of group $g$ in period $t$.

52. When analysing changes in relative incomes over time, changing shares can lead to counter-intuitive results. For instance, an increase in the weight of households with no worker (which have lower average incomes) would reduce the mean income of the total population even if there were no change in average income of the individual groups. As a result, it may appear that all groups gain relative to the average. 


\subsubsection{Contribution of income components to changes in relative disposable income by group}

56. For each group of the population the per cent change in relative disposable income was calculated as (dotted lines in Figures 4.1 to 4.6):

$$
\text { [2] } \quad \&_{g}^{\&}=\frac{\tilde{y}_{g}^{t}}{\tilde{y}_{g}^{0}}-1
$$

where $t$ is the current period and 0 is the initial period. From [2] an additive decomposition in terms of contribution $\left(C_{i, g}\right)$ of income sources can be derived:

$$
\text { [3] } \quad \log _{g}=\sum_{i} c_{i, g}=\sum_{i}\left(\frac{\left(\frac{s_{i, g}^{t}}{s_{i, g}^{0}}\right)}{\left(\frac{\tilde{y}_{g}^{t}}{\tilde{y}_{g}^{0}}\right)}-1\right) \cdot s_{i, g}^{0}
$$

where $\quad \sum_{g} s_{i, g}^{t}=1$; and for each group g, $s_{i, g}^{t}$ is the share of each source $\mathrm{i}$ in disposable income. The term in the numerator within brackets is the growth rate of source i relative to the mean income for the population group considered. In other words, the contribution of each source is measured by its relative growth rate, weighted by its share in the initial period.

57. Tables 4.4 and 4.5 show the contribution of work attachment to the changes in relative earnings for specific groups. Relative earnings of each group is measured as the weighted sum of relative earnings across the three work-attachment categories (non-worker, one worker and two workers):

$$
\text { [4] } \quad e_{g}^{t}=\sum_{j} w_{j, g}^{t} \cdot e_{j, g}^{t}
$$

where $w_{j, g}^{t}$ and $y_{j, g}^{t}$ indicate, respectively, the weight of work attachment $j$ in period $t$ and its relative earnings. Changes in relative earnings of each group can be derived using the first difference of equation [4] as follows:

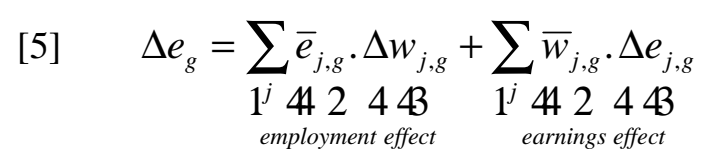

58. These two components are: $i$ ) the employment effect -- i.e. that part of the changes in relative earnings due to the shifts in the shares of individuals across work-attachment categories; and ii) the earnings effect -- that part of the change in relative earnings of each group due to the change in relative earnings of non-worker, one worker and two workers. 


\section{ECO/WKP(98)2}

\subsection{MLD decompositions}

59. The decomposition of the aggregate MLD index in terms of groups of the population shown in Tables 4.9 and 4.10 of the main text, is a modification of the methodology found in Zyblock (1996). The mean $\log$ deviation is:

$$
\text { [6] } \quad M L D=\frac{1}{n} \sum_{i} \ln \left(\frac{\bar{y}}{y_{i}}\right),
$$

where $\bar{y}$ is average equivalent disposable income; $\mathrm{y}_{i}$ is the income of the $i^{\text {th }}$ individual; and $n$ is the number of individuals.

60. When considering sub-groups of the population, this indicator is additively decomposable into:

- The within-group component -- defined as the weighted sum of the MLD of each group $\left(M L D_{g}^{t}\right)$. The MLD of each group indicates the distribution of income within specific groups; their sum, weighted with the share of each group in the population, shows the importance of the inequality within all groups of the population for total inequality.

- The between-group component -- calculated as deviation of the income of the group $\left(y_{g}\right)$ relative to population mean income $(\bar{y})$-- indicates how much the total MLD is affected by differences in relative mean income between groups. This corresponds to the inverse of the relative income of each group described above.

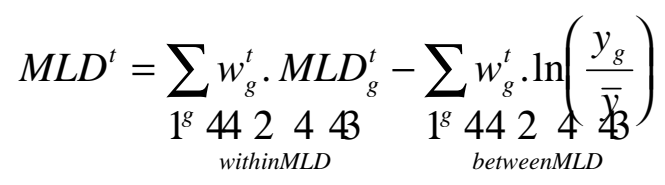

61. To decompose changes of the MLD index over time (for any breakdown by population group), the first difference of equation [7] is:

[8]

$$
\begin{aligned}
& \triangle M L D=M L D^{t}-M L D^{0}
\end{aligned}
$$

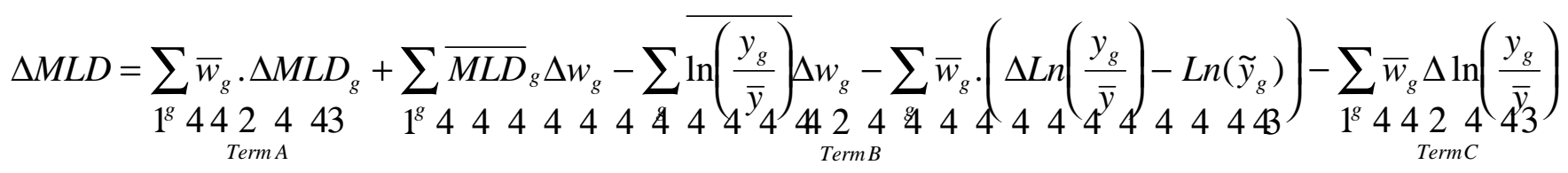

The three terms on the right-hand side of [8] are:

- term A: the impact of "pure" changes of inequality within each group, keeping the structure of the population constant;

- term B: the structural component -- i.e. the effect of the changes in the population structure keeping constant the within-group and between-group components;

- term C: the impact of "pure" changes in inequality between groups when the population structure is held constant. 


\section{Table A1.1 Comparison of inequality indices: Luxembourg Income Study and the OECD Questionnaire}

\begin{tabular}{|c|c|c|c|c|c|}
\hline \multirow[b]{3}{*}{ Australia } & \multicolumn{5}{|c|}{$\begin{array}{l}\text { Gini Coefficients } \\
\text { Equivalence scale elasticity }=0.5\end{array}$} \\
\hline & \multicolumn{2}{|c|}{$\begin{array}{l}\text { Standardised Estimates } \\
\text { (Atkinson et al., 1995) }\end{array}$} & \multicolumn{3}{|c|}{ Estimates from current Questionnaire } \\
\hline & $\begin{array}{l}1981 \\
28.7\end{array}$ & $\begin{array}{r}1985 \\
29.5\end{array}$ & $\begin{array}{c}1975 / 76 \\
29.1\end{array}$ & $\begin{array}{r}1984 \\
31.2\end{array}$ & $\begin{array}{c}1993 / 94 \\
30.6\end{array}$ \\
\hline Belgium & $\begin{array}{l}1985 \\
22.8\end{array}$ & $\begin{array}{r}1988 \\
23.5\end{array}$ & & $\begin{array}{r}1983 \\
25.9\end{array}$ & $\begin{array}{r}1995 \\
27.2\end{array}$ \\
\hline Canada & $\begin{array}{r}1981 \\
28.6\end{array}$ & $\begin{array}{r}1987 \\
28.9\end{array}$ & $\begin{array}{r}1975 \\
28.3\end{array}$ & $\begin{array}{r}1985 \\
28.9\end{array}$ & $\begin{array}{r}1994 \\
28.4\end{array}$ \\
\hline Finland & & $\begin{array}{l}1987 \\
20.7\end{array}$ & & $\begin{array}{r}1986 \\
21.0\end{array}$ & $\begin{array}{l}1995 \\
23.0\end{array}$ \\
\hline France & $\begin{array}{r}1979 \\
29.7\end{array}$ & $\begin{array}{r}1984 \\
29.6\end{array}$ & $\begin{array}{r}1979 \\
29.6\end{array}$ & $\begin{array}{r}1984 \\
29.8\end{array}$ & $\begin{array}{r}1990 \\
29.1\end{array}$ \\
\hline Germany & & $\begin{array}{r}1984 \\
25.0\end{array}$ & & $\begin{array}{r}1984 \\
26.5\end{array}$ & $\begin{array}{r}1994 \\
28.2\end{array}$ \\
\hline Italy & & $\begin{array}{l}1986 \\
31.0\end{array}$ & & $\begin{array}{r}1984 \\
30.6\end{array}$ & $\begin{array}{r}1993 \\
34.5\end{array}$ \\
\hline Netherlands & $\begin{array}{l}1983 \\
23.5\end{array}$ & $\begin{array}{l}1987 \\
26.8\end{array}$ & $\begin{array}{l}1977 \\
23.0\end{array}$ & $\begin{array}{l}1985 \\
23.4\end{array}$ & $\begin{array}{l}1994 \\
25.3\end{array}$ \\
\hline Norway & $\begin{array}{l}1979 \\
22.2\end{array}$ & $\begin{array}{l}1986 \\
23.4\end{array}$ & & $\begin{array}{l}1986 \\
23.4\end{array}$ & $\begin{array}{l}1995 \\
25.6\end{array}$ \\
\hline Sweden & $\begin{array}{r}1981 \\
19.9\end{array}$ & $\begin{array}{r}1987 \\
22.0\end{array}$ & $\begin{array}{r}1975 \\
23.2\end{array}$ & $\begin{array}{r}1983 \\
21.6\end{array}$ & $\begin{array}{r}1994 \\
23.0\end{array}$ \\
\hline United States & $\begin{array}{l}1979 \\
30.9\end{array}$ & $\begin{array}{l}1986 \\
34.1\end{array}$ & $\begin{array}{r}1974 \\
31.3\end{array}$ & $\begin{array}{r}1984 \\
34.0\end{array}$ & $\begin{array}{l}1995 \\
34.4\end{array}$ \\
\hline
\end{tabular}

Note: Years covered in the two sources are not the same. Shaded areas in the table correspond to the years in each source which are closer.

Source: $\quad$ OECD Questionnaire and Atkinson et al., 1995. 


\section{Table A1.2 Characteristics of surveys and sample size}

\begin{tabular}{|c|c|c|c|c|}
\hline & Australia & Belgium & Canada & Denmark \\
\hline $\begin{array}{l}\text { Name of survey, } \\
\text { administrating organisation }\end{array}$ & $\begin{array}{l}\text { Household Expenditure Survey, } \\
\text { Australian Bureau of Statistics }\end{array}$ & $\begin{array}{l}\text { Data constructed from } 4 \text { data } \\
\text { files of the Ministry of Finance }\end{array}$ & $\begin{array}{l}\text { Survey of consumer finances, } \\
\text { Statistics Canada }\end{array}$ & Law model data base \\
\hline Years covered & $\begin{array}{l}1975 / 76 \\
1984 \\
1993 / 94 \\
\end{array}$ & $\begin{array}{l}1983 \\
1995\end{array}$ & $\begin{array}{l}1975 \\
1985 \\
1990,1994 \\
\end{array}$ & $\begin{array}{l}1983 \\
1994 \\
\end{array}$ \\
\hline Population coverage & $\begin{array}{l}\text { households resident in private } \\
\text { dwellings }\end{array}$ & $\begin{array}{l}\text { individuals included in tax files; } \\
\text { excludes those not filing ( } 14 \% \text { of } \\
\text { population) }\end{array}$ & $\begin{array}{l}\text { excludes institutional and } \\
\text { military in barracks; Yukon/ } \\
\text { Northwest territory; homeless }\end{array}$ & \\
\hline $\begin{array}{l}\text { Sample size } \\
\text { (most recent survey) }\end{array}$ & 9733 dwellings & 25000 individuals & 45051 households & $1 / 30$ of all households \\
\hline $\begin{array}{l}\text { Response rate } \\
\text { (most recent survey) }\end{array}$ & $86 \%$ & $96 \%$ & $75 \%$ & \\
\hline Definition of reference person & $\begin{array}{l}1975 \text { and 1984: stipulated by } \\
\text { household } \\
\text { 1994: according to age, } \\
\text { relationship, children, income }\end{array}$ & $\begin{array}{l}\text { the declaring tax person, the } \\
\text { husband in a 2-person } \\
\text { household }\end{array}$ & head of primary economic family & $\begin{array}{l}\text { male person; if no or several } \\
\text { male persons present, person } \\
\text { with the highest disposable } \\
\text { income }\end{array}$ \\
\hline Definition of income unit & $\begin{array}{l}\text { household (group of people who } \\
\text { usually reside and eat together) }\end{array}$ & $\begin{array}{l}\text { tax unit, tax payer, wife, children } \\
\text { and grandchildren and other } \\
\text { dependent persons }\end{array}$ & $\begin{array}{l}\text { household (group of people who } \\
\text { occupy a private dwelling) }\end{array}$ & \\
\hline Income recorded & $\begin{array}{l}\text { current usual cash income } \\
\text { before deductions }\end{array}$ & $\begin{array}{l}\text { taxable income, but capital } \\
\text { income is underestimated }\end{array}$ & edited survey income & \\
\hline $\begin{array}{l}\text { Treatment of missing and } \\
\text { negative incomes }\end{array}$ & $\begin{array}{l}\text { imputation for partial response; } \\
\text { negative incomes set to zero in } \\
1975 \text { and } 1984\end{array}$ & negative values set to zero & $\begin{array}{l}\text { imputation of income details for } \\
\text { non-respondents }\end{array}$ & $\begin{array}{l}\text { negative income sources set to } \\
\text { zero; negative disposable } \\
\text { income removed from sample }\end{array}$ \\
\hline Data transformation & income tax imputed in 1993/94 & & $\begin{array}{l}\text { social assistance, } \\
\text { unemployment compensation } \\
\text { imputed }\end{array}$ & no top coding applied \\
\hline
\end{tabular}


Table A1.2 (cont.) Characteristics of surveys and sample size

\begin{tabular}{|c|c|c|c|c|c|}
\hline & Finland & France & Germany & Italy & Japan \\
\hline $\begin{array}{l}\text { Name of survey, } \\
\text { administrating organisation }\end{array}$ & $\begin{array}{l}\text { Finnish income distribution } \\
\text { survey, } \\
\text { Statistics Finland }\end{array}$ & $\begin{array}{l}\text { Revenus fiscaux, } \\
\text { INSEE }\end{array}$ & Socio-Economic Panel & $\begin{array}{l}\text { Survey of household income } \\
\text { and wealth, Bank of Italy }\end{array}$ & $\begin{array}{l}\text { National Survey of Family } \\
\text { Income and Expenditure } \\
\text { Statistics Bureau }\end{array}$ \\
\hline Years covered & $\begin{array}{l}1986 \\
1995\end{array}$ & $\begin{array}{l}1979 \\
1984 \\
1990\end{array}$ & $\begin{array}{l}1984 \\
1989,1994\end{array}$ & $\begin{array}{l}1984 \\
1991,1993 \\
\end{array}$ & 1974, 1984, 1994 \\
\hline Population coverage & $\begin{array}{l}\text { persons living in private } \\
\text { households }\end{array}$ & & & $\begin{array}{l}\text { Resident non-institutional } \\
\text { population }\end{array}$ & $\begin{array}{l}\text { resident Japanese non- } \\
\text { institutional population excluding } \\
\text { persons providing temporary } \\
\text { accommodation or restaurants } \\
\text { and certain single-person } \\
\text { households }\end{array}$ \\
\hline $\begin{array}{l}\text { Sample size (most recent } \\
\text { survey) }\end{array}$ & 12800 households & 33000 households & $\begin{array}{l}5900 \text { households in } 1984 \text {, } \\
4600 \text { in } 1994\end{array}$ & 8089 households & around 60000 households \\
\hline $\begin{array}{l}\text { Response rate (most recent } \\
\text { survey) }\end{array}$ & $74 \%$ (panel I), $95 \%$ (panel II) & & around 95 per cent & 74 to $86 \%(?)$ & \\
\hline Definition of reference person & $\begin{array}{l}\text { determined on basis of } \\
\text { register-based income and } \\
\text { main-occupation during the } \\
\text { year (in general, person with } \\
\text { highest income) }\end{array}$ & $\begin{array}{l}\text { head of tax unit; determined } \\
\text { by activity, gender and age }\end{array}$ & household & $\begin{array}{l}\text { person who carries major } \\
\text { responsibility for households }\end{array}$ & person with highest income \\
\hline Definition of income unit & $\begin{array}{l}\text { household (persons living } \\
\text { together and having wholly or } \\
\text { partly common household } \\
\text { arrangements) }\end{array}$ & tax unit & chosen by interviewer & household & $\begin{array}{l}\text { persons sharing travelling and } \\
\text { living expenses (sometimes } \\
\text { domestic help) }\end{array}$ \\
\hline Income recorded & & $\begin{array}{l}\text { all taxable incomes (excludes } \\
\text { employee social insurance } \\
\text { contributions) }\end{array}$ & reported survey income & $\begin{array}{l}\text { edited survey income, net of } \\
\text { taxes and social security } \\
\text { contributions }\end{array}$ & reported pre-tax income \\
\hline $\begin{array}{l}\text { Treatment of missing and } \\
\text { negative incomes }\end{array}$ & & & $\begin{array}{l}\text { incomes below social } \\
\text { minimum are included }\end{array}$ & $\begin{array}{l}\text { non-response income is imputed } \\
\text { based on regression models }\end{array}$ & $\begin{array}{l}\text { missing incomes excluded; } \\
\text { negative disposable income } \\
\text { values set to zero }\end{array}$ \\
\hline Data transformation & $\begin{array}{l}\text { specific income items imputed } \\
\text { (e.g. interest income) }\end{array}$ & $\begin{array}{l}\text { minimum pension imputed } \\
\text { where applicable }\end{array}$ & $\begin{array}{l}\text { taxes and social security } \\
\text { contributions imputed }\end{array}$ & $\begin{array}{l}\text { taxes, social security } \\
\text { contributions and family } \\
\text { transfers imputed on the basis of } \\
\text { ITAXMOD micro-simulation } \\
\text { model; net income from self- } \\
\text { employment corrected }\end{array}$ & $\begin{array}{l}\text { taxes and social security } \\
\text { contributions were imputed }\end{array}$ \\
\hline
\end{tabular}




\section{Table A1.2 (cont.) Characteristics of surveys and sample size}

\begin{tabular}{|c|c|c|c|c|}
\hline & $\begin{array}{l}\text { Netherlands } \\
\end{array}$ & Norway & Sweden & United States \\
\hline $\begin{array}{l}\text { Name of survey, } \\
\text { administrating organisation }\end{array}$ & $\begin{array}{l}\text { Income survey }(1977,1985) \text { and } \\
\text { Income panel survey }(1990, \\
\text { 1994), both based on tax } \\
\text { records; CBS }\end{array}$ & $\begin{array}{l}\text { Income Distribution Survey, } \\
\text { Statistics Norway; drawn from } \\
\text { the Central Population Register }\end{array}$ & $\begin{array}{l}\text { Income Distribution Survey, } \\
\text { based on tax records; Statistics } \\
\text { Sweden }\end{array}$ & $\begin{array}{l}\text { Current Population Survey; } \\
\text { US Bureau of the Census }\end{array}$ \\
\hline Years covered & $\begin{array}{l}1977 \\
1985 \\
1990,1994 \\
\end{array}$ & $\begin{array}{l}1986 \\
1990 \\
1995 \\
\end{array}$ & $\begin{array}{l}1975 \\
1983 \\
1990,1991,1994 \\
\end{array}$ & $\begin{array}{l}1974,1979 \\
1984 \\
1989,1994 \\
\end{array}$ \\
\hline Population coverage & $\begin{array}{l}\text { all residents, excluding persons } \\
\text { living in households with } \\
\text { persons aged under } 18 \text { only }\end{array}$ & $\begin{array}{l}\text { Resident population excluding } \\
\text { long-term institutional } \\
\text { population }\end{array}$ & $\begin{array}{l}\text { Residents living in "whole year } \\
\text { households", excluding } \\
\text { institutional population }\end{array}$ & Non-institutional population \\
\hline $\begin{array}{l}\text { Sample size (most recent } \\
\text { survey) }\end{array}$ & 75256 households & $\begin{array}{l}5000 \text { in } 1986 ; \\
10000 \text { in } 1995\end{array}$ & 12977 households/family units & 50000 households \\
\hline $\begin{array}{l}\text { Response rate (most recent } \\
\text { survey) }\end{array}$ & - & & $\begin{array}{l}79.4 \% \text { for survey; } \\
99 \% \text { for tax records }\end{array}$ & $93.6 \%$ \\
\hline Definition of reference person & $\begin{array}{l}\text { male, or person with highest } \\
\text { earnings }\end{array}$ & & $\begin{array}{l}\text { person with largest income, or } \\
\text { oldest person }\end{array}$ & $\begin{array}{l}\text { person who owns or rents } \\
\text { housing unit }\end{array}$ \\
\hline Definition of income unit & housekeeping unit & $\begin{array}{l}\text { shared residence and common } \\
\text { housekeeping }\end{array}$ & $\begin{array}{l}\text { family unit (children aged } 18 \text { and } \\
\text { over are treated as separate } \\
\text { unit) }\end{array}$ & household \\
\hline Income recorded & $\begin{array}{l}\text { taxable income; excluding } \\
\text { private pension premia }\end{array}$ & most cash income & taxable income & pre-tax surveyed income \\
\hline $\begin{array}{l}\text { Treatment of missing and } \\
\text { negative incomes }\end{array}$ & $\begin{array}{l}\text { zero and negative incomes } \\
\text { excluded }\end{array}$ & none & & \\
\hline Data transformation & $\begin{array}{l}\text { break between } 1985 \text { and } 1990 \\
\text { (student grants and fiscal } \\
\text { reform): two series for } 1985 \\
\text { have been provided }\end{array}$ & $\begin{array}{l}\text { Unemployment benefits included } \\
\text { in earnings }\end{array}$ & break in 1990 (fiscal reform) & $\begin{array}{l}\text { all taxes including EITC imputed } \\
\text { using tax model; non-response } \\
\text { incomes imputed using "hot } \\
\text { deck" method; highest income } \\
\text { top-coded }\end{array}$ \\
\hline
\end{tabular}

Source: OECD. 
Table A.1.3. Contribution of income components to the total change

in the SCV index: a numerical example

A. Calculation of contribution of income components to change in the SCV index

(columns marked "Total" in Table 3.4)

earliest period ${ }^{1}$

(1) Proportional contributions of income component $\left(\mathbf{s}_{k}\right)$ (Table 3.3, left-hand panel)

(2) SCV index

(3) SCV contribution of income component $\left(\mathrm{SCV}_{\mathrm{k}}\right)$ (line 1 * line 2)

latest period $^{1}$

(4) Proportional contributions of income component $\left(\mathrm{s}_{\mathrm{k}}\right)$ (Table 3.3, left-hand panel)

(5) SCV index

(6) SCV contribution of income component $\left(\mathrm{SCV}_{\mathrm{k}}\right)$ (line 4 * line 5)

(7) Change in proportional contributions $\left(s_{k}\right)$ of income component (Table 3.3, left-hand panel) (line 4 - line 1)

(8) Change in $\mathrm{SCV}_{\mathrm{k}}$ contribution of income component (Table 3.4) (line 6 - line 3)

of which ${ }^{2}$ :

effect of change in contribution

effect of change in SCV

\begin{tabular}{|c|c|c|c|}
\hline \multicolumn{2}{|c|}{ Australia } & \multicolumn{2}{|c|}{ Finland } \\
\hline Taxes & Transfers & Taxes & Transfers \\
\hline-20.1 & -5.5 & -65.6 & -5.0 \\
\hline 32.7 & 32.7 & 16.4 & 16.4 \\
\hline-6.6 & -1.8 & -10.8 & -0.8 \\
\hline-49.8 & -13.5 & -56.7 & -11.3 \\
\hline 37.5 & 37.5 & 24.3 & 24.3 \\
\hline-18.7 & -5.1 & -13.8 & -2.7 \\
\hline-29.8 & -8.1 & 8.9 & -6.3 \\
\hline-12.1 & -3.3 & -3.0 & -1.9 \\
\hline-10.4 & -2.8 & 1.8 & -1.3 \\
\hline-1.7 & -0.5 & -4.8 & -0.6 \\
\hline-7.7 & 6.3 & -35.2 & 19.6 \\
\hline 0.9 & -0.3 & 0.3 & 0.0 \\
\hline-23.2 & 15.7 & -33.7 & 23.7 \\
\hline 0.8 & -0.3 & 0.4 & -0.1 \\
\hline-12.9 & -2.9 & 0.5 & -0.3 \\
\hline 0.8 & -0.4 & -3.5 & -1.6 \\
\hline-12.1 & -3.3 & -3.0 & -1.9 \\
\hline
\end{tabular}

B. Calculation of the effect of changes in income shares and component inequality to changes in SCV contributions (columns marked "Part due to contribution of: share and component inequality in Table 3.4)

earliest period ${ }^{\dagger}$

(9) Share of component in earliest period (Table 3.3, middle panel)

(10) Component inequality (line 3 / line 9)

latest period $^{1}$

(11) Share of component in earliest period (Table 3.3, middle panel)

(12) Component inequality (line 6 / line 11)

Shift share analysis:

(13) Part due to change in shares (Table 3.4)

(14) Part due to change in component inequality (Table 3.4)

15) Contribution to change in SCV (Table 3.4) (line 8)

1. Earliest and latest year are respectively for Australia 1974/75 and 1993/94, and for Finland 1986 and 1995.

2. The change in the SCV contribution can be broken down into the impact of changes in the proportional contribution (s) -- holding the SCV constant -- and the impact of the change in the overall SCV -- holding the proportional contribution constant $\left(\mathbf{S}_{k}\right)$. 


\section{BIBLIOGRAPHY}

ATKINSON, A.B., L. Rainwater and T.M. Smeeding (1995), "Income distribution in OECD countries, Evidence from the Luxembourg Income Study", Income Distribution in OECD Countries, OECD Social Policy Studies No. 18, Paris.

BRANDOLINI, A. and P. Sestito (1994), "Cyclical and trend changes in inequality in Italy, 1977-1991", 23rd General Conference of the IARIW, St. Andrews, Canada, 21-27 August.

BUHMANN, B., L. Rainwater, G. Schmaus and T.M. Smeeding (1988), "Equivalence scales, well-being, inequality, and poverty: sensitivity estimates across ten countries using the Luxembourg Income Study (LIS) database", The Review of Income and Wealth, 34, pp. 115-142, June.

BURKHAUSER, R., T. Smeeding and J. Merz (1996), "Relative inequality and poverty in Germany and the United States using alternative equivalence scales", Review of Income and Wealth, 42:4, pp. 381-419.

CUTLER, D. and L. Katz (1991), "Macroeconomic performance and the disadvantaged", Brookings Papers on Economic Activity, No. 2, pp. 1-74.

DANISH MINISTRY OF FINANCE (1997), Distributional Outcome of the Danish Welfare System, mimeo., March.

GILLES-SIMON, M-O. and M. Legros (1997), "Les politiques sociales du point de vue des populations pauvres", Economie et Statistique, n 303, pp. 33-43.

GOODMAN, A., P. Johnson and S. Webb (1997), Inequality in the UK, Oxford University Press.

JOHNSON, S. (1995), "More evidence on the effect of higher unemployment on the Canadian size distribution of income", Canadian Public Policy, No. 4, pp. 423-428.

LUNDBERG, S. and R. Pollak (1996), "Bargaining and distribution in marriage", Journal of Economic Perspectives, Vol. 10, No. 4, pp. 139-158.

OECD (1997a), Implementing the OECD Jobs Strategy: Lessons From Member Countries' Experience, Paris.

OECD (1997b), Employment Outlook, Chapter 2, Paris.

OECD (1996), Strategies for Housing and Social Integration in Cities, Paris.

OECD (1994), The OECD Jobs Study, Paris.

OECD (1988), The Future of Social Protection, OECD Social Policy Studies No. 6, Paris. 
RADNER, D. (1983), "Adjusted estimates of the size distribution of family money income", Journal of Business and Economic Statistics, Vol. 1, pp. 135-146.

SHARPE, A. and M. Zyblock (1996), "Macroeconomic performance and income distribution in Canada", Human Resources Canada, Draft Working Paper.

SHORROCKS, A.F. (1982), "Inequality decomposition by factor components", Econometrica, Vol. 50, No. 1.

SLESNICK, D. (1993), "Gaining ground: poverty in the postwar United States", Journal of Political Economy, Vol. 101, No. 1, pp. 1-38.

SLESNICK, D. (1994), "Consumption, needs and inequality", International Economic Review, Vol. 35, No. 3, pp. 677-703.

TOWNSEND, P. (1979), Poverty in the United Kingdom. a Survey of Household Resources and Standards of Living, Harmondsworth: Penguin.

ZYBLOCK, M. (1996), "Why is family market income inequality increasing in Canada?", Working Paper, Human Resources Development Canada 
ECO/WKP(98)2

\section{ECONOMICS DEPARTMENT \\ WORKING PAPERS}

188. Asset Prices and Monetary Policy

(February 1998) Mike Kennedy, Angel Palerm, Charles Pigott and Flavia Terribile

187. NAIRU: Incomes Policy and Inflation

(January 1998) Silvia Fabiani, Alberto Locarno, Gian Paolo Oneto and Paolo Sestito

186. OECD Submission to the Irish National Minimum Wage Commission

(December 1997)

185. OECD Submission to the UK Low Pay Commission

(December 1997)

184. Concept, Measurement and Policy Implications of the NAIRU - Perspective from Belgium (October 1997) Joost Verlinden

183. Structural unemployment in Denmark

(September 1997) Agnete Gersing

182. The United Kingdom NAIRU: Concepts, Measurement and Policy Implications (September 1997) Chris Melliss and A.E. Webb

181. Globalisation and Linkages: Macro-Structural Challenges and Opportunites (August 1997) Pete Richardson

180. Regulation and Performance in the Distribution Sector (August 1997) Dirk Pilat

179. Measurement of Non-tariff Barriers (July 1997) Alan Deardorff and Robert M. Stern

178. The NAIRU-Concept: A Few Remarks

(July 1997) Karl Pichelmann and Andreas Ulrich Schuh

177. Structural Unemployment in Finland

(July 1997) Pasi Holm and Elina Somervouri

176. Taxation and Economic Performance

(June 1997) Willi Leibfritz, John Thornton and Alexandra Bibbee

175. Long-Term Interest Rates in Globalised Markets

(May 1997) Hans Christiansen and Charles Pigott

174. International Implications of European Economic and Monetary Union (May 1997) Norbert Funke and Mike Kennedy

173. The NAIRU in Japan: Measurement and its implications (March 1997) Fumihira Nishizaki 
172. The Unemployment Problem - A Norwegian Perspective (February 1997) Steinar Holden

171. The Reliability of Quarterly National Accounts in Seven Major Countries: A User's Perspective (February 1997) Robert York and Paul Atkinson

170. Confidence Indicators and their Relationship to changes in Economic Activity (November 1996) Teresa Santero and Niels Westerlund.

169. Labour Productivity Levels in OECD Countries. Estimates for Manufacturing and Selected Service Sectors (September 1996) Dirk Pilat

168. Ageing Populations, Pension Systems and Government Budgets: Simulations for 20 OECD Countries (September 1996) Deborah Roseveare, Willi Leibfritz, Douglas Fore and Eckhard Wurzel

167. Modelling the Supply Side of the Seven Major OECD Economies (September 1996) Dave Turner, Pete Richardson and Sylvie Rauffet

166. Size Distribution of Output and Employment: A Data Set For Manufacturing Industries in Five OECD Countries, 1960s-1990 (August 1996) Bart van Ark and Erik Monnikhof

165. Trade and Competition: Frictions after the Uruguary Round (July 1996) International Trade and Investment Division

164. Corporate Governance, Competition and Performance (June 1996) Colin Mayer

163. Fiscal Relations within the European Union (May 1996) Peter Hoeller, Marie-Odile Louppe and Patrice Vergriete

162. Mark-Up Ratios in Manufacturing Industries (April 1996) Joaquim Oliveira Martins, Stefano Scarpetta and Dirk Pilat

161. Innovation, Firm Size and Market Structure: Schumpeterian Hypothesesand some new Themes (April 1996) George Symeonidis

160. Valuing the right to Tax Incomes: An Options Pricing Approach (April 1996) Teun Draaisma and Kathryn Gordon

159. Innovation and Competitive Advantage (October 1995) P.A. Geroski

158. Monetary Policy at Price Stability: A review of some issues (September 1995) Malcolm Edey, Norbert Funke, Mike Kennedy and Angel Palerm

157. Technical Progress, Factor Productivity and Macroeconomic Performance in the Medium Term (September 1995) Claude Giorno, Pete Richardson and Wim Suyker 